


\section{Literatuurstudie voercontrole vleeskuikenouderdieren}

Rick van Emous

Dit onderzoek is uitgevoerd door Wageningen Livestock Research binnen het kader van de Publiek Private Samenwerking (PPS) "Vital Chick Chain" (BO-63-001-032). Dit project is een samenwerking tussen het Ministerie van Landbouw, Natuur en Voedselkwaliteit en een consortium van verschillende partijen.

Wageningen Livestock Research

Wageningen, december 2020

Openbaar

Rapport 1291 
R.A. van Emous, 2020. Literatuurstudie voercontrole vleeskuikenouderdieren. Openbaar Wageningen Livestock Research, Rapport 1291.

Voercontrole bij vleeskuikenouderdieren is al jaren een controversieel onderwerp waarbij de diverse stakeholders, namelijk vermeerderaars, (gedrags)wetenschappers, fokkerijorganisaties en dierenbelangenorganisaties van elkaar van mening verschillen. Het doel van dit rapport is om de beschikbare literatuur, data en beschikbare kennis over dit onderwerp te verzamelen om een meer gedegen onderbouwing te hebben ten behoeve van de discussie omtrent de voercontrole bij vleeskuikenouderdieren. Uit berekeningen blijkt dat de gemiddelde energiecontrole tijdens de opfoken legperiode respectievelijk $47 \%$ en $35 \%$ is, wat lager is dan in de literatuur wordt aangegeven Doordat ouderdieren niet exact hetzelfde groeipotentieel hebben, en door het heterosis effect bij de nakomelingen, is dit mogelijk een overschatting en zal de werkelijke controle wat lager zijn. In dit rapport is een schatting gemaakt van $10 \%$ wat de energiecontrole tijdens de opfok- en legperiode op $42 \%$ en $31 \%$ brengt. Verder blijkt dat stereotiep pikgedrag naar objecten en staart en de verhouding van heterofielen en basofielen t.o.v. lymfocyten ( $H / L$ en $B / L$ ratio's) redelijk betrouwbare welzijnsindicatoren voor de mate van voercontrole te zijn. Over het algemeen lijkt afwijkend pikgedrag tijdens de opfokperiode vooral te maken hebben met tijdsbesteding en minder met honger en frustratie. Een combinatie van maatregelen om de gevolgen van voercontrole te verminderen lijkt het meeste effect te genereren, omdat de maatregelen alleen onvoldoende effecten geven. Daarbij wordt gedacht aan een combinatie van o.a. de volgende maatregelen: meerdere keren per dag voeren, verschillende methoden van voer verstrekken en verdund voer. Daarnaast geeft het onbeperkt verstrekken van water tijdens de opfokperiode mogelijk rustiger dieren. Het vaststellen van de mate van honger bij vleeskuikenouderdieren kan alleen via een combinatie van (indirecte) observaties die niet altijd eenduidig is. Vanwege gezondheids- en welzijnsredenen krijgen huis- en laboratoriumdieren een 20 tot $25 \%$ lagere voergift wat aangeeft dat een bepaalde mate van voercontrole bij alle levende dieren nodig is.

Dit rapport is gratis te downloaden op https://doi.org/10.18174/539675of op www.wur.nl/livestock-research (onder Wageningen Livestock Research publicaties).

\section{(cc) BY-NC}

Dit werk valt onder een Creative Commons Naamsvermelding-Niet Commercieel 4.0 Internationaallicentie.

(C) Wageningen Livestock Research, onderdeel van Stichting Wageningen Research, 2021

De gebruiker mag het werk kopiëren, verspreiden en doorgeven en afgeleide werken maken. Materiaal van derden waarvan in het werk gebruik is gemaakt en waarop intellectuele eigendomsrechten berusten, mogen niet zonder voorafgaande toestemming van derden gebruikt worden. De gebruiker dient bij het werk de door de maker of de licentiegever aangegeven naam te vermelden, maar niet zodanig dat de indruk gewekt wordt dat zij daarmee instemmen met het werk van de gebruiker of het gebruik van het werk. De gebruiker mag het werk niet voor commerciële doeleinden gebruiken.

Wageningen Livestock Research aanvaardt geen aansprakelijkheid voor eventuele schade voortvloeiend uit het gebruik van de resultaten van dit onderzoek of de toepassing van de adviezen.

Wageningen Livestock Research is NEN-EN-ISO 9001:2015 gecertificeerd.

Op al onze onderzoeksopdrachten zijn de Algemene Voorwaarden van de Animal Sciences Group van toepassing. Deze zijn gedeponeerd bij de Arrondissementsrechtbank Zwolle. 


\section{Inhoud}

Woord vooraf $\quad 5$

$\begin{array}{ll}\text { Samenvatting } & 7\end{array}$

1

Inleiding

2

$\begin{array}{ll}\text { Vleeskuikenouderdieren } & 12\end{array}$

2.1 Beschrijving sector $\quad 12$

2.2 Vleeskuiken versus leghen 13

2.3 Ontwikkeling vleeskuiken 14

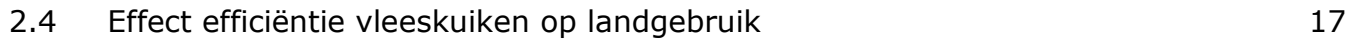

2.5 Huisvesting en management opfokperiode 19

2.6 Huisvesting en management legperiode $\quad 21$

$\begin{array}{ll}2.7 & \text { Reproductie ouderdieren } \\ 2.8 & 23\end{array}$

$\begin{array}{lll}2.8 & \text { Samenvatting vleeskuikenouderdieren } & 24\end{array}$

3

$\begin{array}{ll}\text { Niveau voercontrole } & 25\end{array}$

$\begin{array}{lll}3.1 & \text { Reden voercontrole } & 25\end{array}$

3.2 Voercontrole naar leeftijd of gewicht? $\quad 26$

3.3 Factoriele berekening voercontrole $\quad 28$

3.4 Samenvatting niveau voercontrole $\quad 32$

4.1 Effecten op fysiologie $\quad 33$

4.2 Effecten op gedrag $\quad 34$

4.2.1 Stereotiep pikgedrag $\quad 34$

4.2.2 Verenpikken en verenlikken $\quad 36$

$\begin{array}{ll}4.2 .3 \text { Waterpikken } & 37\end{array}$

4.2.4 Lopen (pacing) 37

4.2.5 Voeropnamemotivatie $\quad 38$

$\begin{array}{lll}4.3 & \text { Effecten op (re)productie en gezondheid } & 38\end{array}$

$\begin{array}{lll}4.4 & \text { Samenvatting effecten voercontrole } & 41\end{array}$

$5 \quad$ Vermindering effecten voercontrole $\quad 42$

5.1 Ad libitum voeding $\quad 42$

$\begin{array}{lll}5.2 & \text { Aangepaste gewichtsschema's } & 43\end{array}$

$\begin{array}{lll}5.3 & \text { Dwergouderdieren } & 43\end{array}$

5.4 Aanpassing voersamenstelling $\quad 44$

$\begin{array}{lll}5.5 & \text { Voerfrequentie of voer strooien } & 44\end{array}$

$\begin{array}{lll}5.6 & \text { Mogelijke oplossingen } & 45\end{array}$

$\begin{array}{lll}5.7 & \text { Samenvatting vermindering effecten voercontrole } & 46\end{array}$

6

$\begin{array}{ll}\text { Honger } & 47\end{array}$

$\begin{array}{lll}6.1 & \text { Definitie van honger } & 47\end{array}$

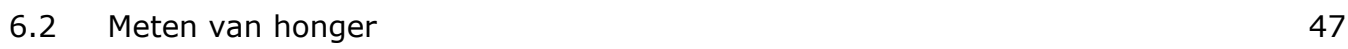

$\begin{array}{lll}6.3 & \text { Samenvatting honger } & 48\end{array}$

$7 \quad$ Voercontrole bij huis- en laboratorium dieren $\quad 49$

$\begin{array}{lll}7.1 & \text { Prevalentie obesitas huisdieren } & 49\end{array}$

7.2 Oorzaken en gevolgen overgewicht huisdieren 49 
$\begin{array}{lll}7.3 & \text { Voercontrole huisdieren } & 50\end{array}$

7.4 Voercontrole laboratorium dieren $\quad 50$

7.5 Samenvatting voercontrole huis- en laboratoriumdieren $\quad 51$

8

Conclusies en aanbevelingen $\quad 52$

$\begin{array}{ll}\text { Literatuur } & 53\end{array}$

Bijlage 1 Overzicht literatuur effecten voercontrole op fysiologie 63

Bijlage 2 Overzicht literatuur effecten voercontrole op gedrag 66

$\begin{array}{lll}\text { Bijlage } 3 & \text { Overzicht literatuur effecten voercontrole op productie } & 72\end{array}$ 


\section{Woord vooraf}

Voercontrole bij vleeskuikenouderdieren is al jaren een belangrijk onderwerp van discussie binnen en buiten de sector. In deze discussie staan de voor- en tegenstanders vaak lijnrecht tegenover elkaar waardoor het lastig is om een gezamenlijk standpunt in te nemen. Men is het in de eerste plaats niet eens over de benaming van het onderwerp, de ene partij hanteert voerbeperking terwijl de andere partij voergiftregulatie gebruikt. Dit geeft duidelijk de moeizame discussie aan over dit onderwerp. In dit rapport wordt de benaming voercontrole gebruikt, omdat dit een neutralere term is.

In dit rapport worden de resultaten gepresenteerd van een literatuurstudie naar de huidige stand van kennis rondom de effecten van voercontrole bij vleeskuikenouderdieren. Daarnaast is onderzoek gedaan naar de mate van voercontrole bij huis- en laboratoriumdieren. De wens is dat dit literatuuroverzicht en interpretatie een gefundeerde bijdrage levert aan de hierboven benoemde discussie.

De auteur bedankt de partners van het PPS project "Vital Chick Chain" voor de financiering en opdracht om dit rapport te schrijven.

Projectleider, Dr. ing. R.A. (Rick) van Emous 


\section{Samenvatting}

\section{Aanleiding en doel}

Voercontrole, met name tijdens de opfokperiode, bij vleeskuikenouderdieren is al jaren een controversieel onderwerp. Vermeerderaars, (gedrags)wetenschappers, fokkerijorganisaties en dierbelangenorganisaties verschillen hierover van mening. De discussie omtrent voercontrole bij vleeskuikenouderdieren komt voort uit de zogenaamde "broiler breeder paradox". De ouders van vleeskuikens worden opgefokt om bevruchte eieren te leggen en daarmee nakomelingen (vleeskuikens) te produceren. Deze ouderdieren hebben min of meer hetzelfde potentieel als vleeskuikens om in korte tijd een hoog gewicht te bereiken. Een te hoog gewicht heeft echter negatieve invloed op de gezondheid, reproductie en welzijn van de ouderdieren. Om die reden zijn er consequenties voor de manier waarop ouderdieren gehouden worden en de hoeveelheid voer die deze dieren krijgen. In het algemeen groeien vleeskuikens in 35 dagen naar een gewicht van 2,3 kilogram terwijl de ouderdieren dat gewicht pas moeten bereiken op 20 weken leeftijd. Vanwege het min of meer vergelijkbaar groeipotentieel, krijgen ouderdieren een kleinere gecontroleerde voerhoeveelheid om datzelfde gewicht te bereiken over een langere periode. De gecontroleerde (kleine) hoeveelheid voer die de dieren krijgen, is met name tijdens de opfokperiode doorgaans in een half uur opgenomen waardoor de dieren tijd over hebben voor andere gedragingen. Deze gedragingen zijn niet altijd positief en kunnen resulteren in stereotiep pikgedrag naar objecten en andere dieren.

Het doel van dit rapport is om literatuur, data en beschikbare kennis over dit onderwerp te verzamelen om een meer gedegen onderbouwing te hebben ten behoeve van de discussie omtrent de voercontrole bij vleeskuikenouderdieren.

\section{Vleeskuikenouderdieren}

Vleeskuikenouderdieren zijn het middelpunt van de pluimveevleesketen omdat ze broedeieren, en dus kuikens, produceren die na een groeiperiode op vleeskuikenbedrijven verwerkt worden tot verschillende soorten pluimveevlees. Het huidige vleeskuiken is ontstaan na circa 70 jaar fokkerij en selectie van oorspronkelijke rassen. Het vleeskuiken is in die 7 decennia veranderd van een smal kuiken van minder dan 500 gram naar een breed kuiken van circa 2,5 kg op 6 weken leeftijd. Daarbij is het aandeel borstfilet bijna verdubbeld en het vetgehalte gehalveerd. Dit heeft grote gevolgen voor de efficiëntie van pluimveevlees waarbij de voederconversie in 70 jaar tijd van ongeveer 3,0 (3 kg voer voor $1 \mathrm{~kg}$ vlees) gehalveerd is naar ongeveer 1,5 . Hierdoor is het landgebruik om gewassen (zoals mais, tarwe en soja) te verbouwen voor de productie van een kilogram vleeskuikenvlees flink afgenomen.

\section{Niveau voercontrole}

In literatuur van 20 tot 25 jaar terug wordt een niveau van voercontrole tijdens de opfokperiode genoemd tussen 66 en 75\%. Dit betekent dus dat de dieren een voergift krijgen van 25 tot $34 \%$ t.o.v. de ad libitum voeropname. Na bestudering van de literatuur en berekeningen blijkt dit niveau echter wat genuanceerder en lager te zijn. Bij voorgaande experimenten en/of berekeningen ging men namelijk uit van de voeropname bij dezelfde leeftijd. De dieren in die experimenten hadden op dezelfde leeftijd bij gecontroleerde en ad libitum voeding echter verschillende lichaamsgewichten. Dieren die zwaarder wegen, hebben een hogere behoefte aan nutriënten voor onderhoud. Daarom is in dit rapport uitgegaan van de theoretische voergift/voeropname bij hetzelfde gewicht (en dus verschillende leeftijd). Daarnaast werd in voorgaande berekeningen geen rekening gehouden met verschillen nutriënten gehalten tussen vleeskuiken- en vleeskuikenouderdierenvoer. Daarom is gekeken naar de werkelijke dagelijkse energieopname wat de werkelijkheid nog beter benadert omdat dieren leven en groeien van de nutriënten (o.a. energie en eiwit) die ze per dag kunnen opnemen. Uit deze berekeningen blijkt dat de energiecontrole tijdens de opfok- en legperiode bij vleeskuikenouderdieren respectievelijk gemiddeld $47 \%$ en $35 \%$ is. Doordat ouderdieren niet exact hetzelfde groeipotentieel en een 3 procentpunt lager aandeel borstvlees hebben als vleeskuikens is dit mogelijk een overschatting en zal de werkelijke energiecontrole wat lager (schatting 10\%) zijn; respectievelijk $42 \%$ en $31 \%$. Dit is beduidend lager dan de 66 tot $75 \%$ en 20 tot 55\% die in de literatuur wordt gehanteerd voor respectievelijk de opfok-en legperiode. 
Daarnaast zijn factoriele berekeningen uitgevoerd om de theoretische behoefte aan energie te berekenen. Uit de berekeningen blijkt dat de dieren tijdens de opfok- en legperiode respectievelijk een $12 \%$ en $3 \%$ lagere energiegift krijgt t.o.v. de energiebehoefte.

\section{Effecten voercontrole}

In diverse literatuur worden verschillende parameters genoemd om de mate van voercontrole te meten. Het gaat hier om bloedparameters in combinatie met gedragsobservaties die het stressniveau indirect kunnen kwantificeren. Uit de literatuur blijkt dat plasma corticosteron concentratie minder geschikt is als welzijnsindicator terwijl hematologische metingen zoals de verhouding tussen heterofielen en basofielen ten opzichte van Iymfocyten ( $H / L$ en B/L ratio's) meer geschikt zijn. Stereotiep pikgedrag naar objecten (leeg watersysteem, roosters, wanden, etc.) en bijvoorbeeld de staart lijken betrouwbare welzijnsindicatoren omdat er een directe relatie lijkt te zijn tussen de mate van voercontrole en objectpikken. Er wordt gesuggereerd dat het staartlikken komt doordat de dieren in eerste instantie naar het vet pikken vanuit de stuitklier. Over de interpretatie van het stereotiep pikken naar een leeg voersysteem zijn ook twijfels gerezen omdat dit ook gefaciliteerd kan worden doordat het pikken naar een lege voerpan kan resulteren in een beloning doordat voerresten uit de aanvoervijzel beschikbaar komen. Aan de andere kant, kan het ook een indicatie zijn van een sterke voeropnamemotivatie om zo veel mogelijk te pikken naar alle kleine voerresten. Het pikken naar water en een hogere wateropname lijkt geen goede welzijnsindicator bij vleeskuikenouderdieren omdat in oudere experimenten de hoge wateropname veroorzaakt werd door een langere daglengte en/of open watersysteem. Actief loopgedrag (pacing) voor het voeren wordt in de literatuur vaak genoemd als indicator voor verminderd welzijn. Dit lijkt echter geen goede welzijnsindicator omdat dit normaal gedrag is bij alle dieren die geconditioneerd zijn op voertijden en dit gedrag ook wordt waargenomen bij huis- en landbouwhuisdieren die minder gecontroleerd gevoerd worden.

Voercontrole bij vleeskuikenouderdieren geeft minder dubbeldooiers en daarmee een lagere kans op prolaps (uitstulping van de cloaca) en dus uitval. Daarnaast zorgt voercontrole ervoor dat de dieren niet te vroeg in productie komen waardoor ze meer persistent zijn en langer productief blijven.

\section{Vermindering effecten voercontrole}

In experimenten zijn opfokdieren regelmatig ad libitum gevoerd om na te gaan wat de effecten daarvan waren. Ad libitum voer verstrekken resulteert in grote problemen met de gezondheid en reproductie door de extreme toename van het gewicht tijdens de opfokperiode. In de literatuur worden een aantal oplossingen aangedragen om de effecten van voercontrole te verminderen:

1. Hoger lichaamsgewicht opfokperiode

Uit de beperkte studies met verschillende gewichtsprofielen blijkt dat een 10 tot 15\% hoger eindgewicht geen effecten geeft op gedrag.

2. Dwergouderdieren of ouderdieren van trager groeiende vleeskuikens

Het grote voordeel van het toepassen van dwergouderdieren of ouderdieren van trager groeiende rassen is dat deze bijna, ook tijdens de opfokperiode, onbeperkt gevoerd kunnen worden.

Ouderdieren van trager groeiende dieren hebben echter grote nadelen op de brede duurzaamheid (People, Planet, Profit) door o.a. hogere voerconversie, hogere landgebruik, hogere uitstoot van $\mathrm{NH}_{3}$ en fijnstof.

3. Aanpassen voersamenstelling of verdunnen voer

Het aanpassen van de voersamenstelling of het verdunnen van het totale voer (met vezels) en of gedeeltelijk (bijv. alleen eiwit of energie) kan helpen om de eettijd te verlengen en daarmee stereotiep pikgedrag te verminderen. Het toevoegen van eetlustonderdrukkers (zoals calciumpropionaat) lijkt geen goede methode omdat bij de meest gebruikte onderdrukkers de dieren zich mogelijk ziek voelen, met een ongewenst effect op het welzijn.

4. Aangepast voermanagement

Het verstrekken van voer op het strooisel lijkt geen grote verbeteringen van het gedrag met zich mee te brengen. Daarentegen lijkt het vaker voeren (bijv. tweemaal) per dag een kansrijke oplossing door de verbeteringen van het gedrag in combinatie met technische resultaten zoals bijvoorbeeld de uniformiteit.

Het stereotiep pikgedrag is een indicator van verminderd welzijn terwijl de voeropname motivatie van de dieren hoog is. Daarnaast is te beargumenteren dat het stereotiep pikgedrag mede ontstaat door een mismatch in tijdsbesteding doordat de dieren het voer te snel opnemen. Een combinatie van maatregelen om de voeropnametijd maximaal te verlengen om de gevolgen van voercontrole te 
verminderen, lijkt het meeste effect te genereren: meerdere keren per dag voeren, verschillende methoden van voer verstrekken en verdund voer. Verder kan het onbeperkt verstrekken van water tijdens de opfokperiode de effecten van het verstrekken van een gecontroleerde voerhoeveelheid verminderen.

\section{Honger}

Onderzoek naar de effecten van voercontrole op honger is de laatste 40 jaar sterk toegenomen. Het meten van honger bij dieren is niet mogelijk via een directe methode en de mate van honger wordt dan ook meestal via een combinatie van indirecte observaties vastgesteld, zoals fysiologische parameters en via gedragsobservaties. Ook de indirecte observaties zijn niet eenvoudig en de verschillende experimenten geven regelmatig tegenstrijdige conclusies.

\section{Voercontrole huis- en laboratoriumdieren}

De prevalentie van overgewicht en obesitas bij honden en katten wordt geschat op respectievelijk $40 \%$ en $32 \%$, en lijkt toe te nemen. De oorzaken van overgewicht en obesitas bij huisdieren zijn multifactorieel, maar beperkte opname van hoge kwaliteit voedsel (hoog niveau nutriënten) waarbij het overschot dat niet nodig is voor onderhoud en beweging, opgeslagen wordt als vetweefsel is de belangrijkste. Daarnaast spelen zaken mee als leeftijd, geslacht, castratie en hormonale invloeden. Overgewicht bij huisdieren kan leiden tot gezondheidsproblemen zoals diabetes mellitus, hartfalen, urinewegaandoeningen, voortplantingsstoornissen, bewegingsproblemen, tumoren en verhoogde mortaliteit. Problemen met overgewicht komen ook veel voor bij laboratoriumdieren als deze voor onderzoeksdoeleinden ad libitum voer verstrekt krijgen. Dit leidt tot negatieve effecten op gezondheid, welke nadelig zijn voor het welzijn van de dieren en ook afwijkende effecten kunnen geven op uitkomsten van experimenten.

Om overgewicht te voorkomen krijgen huis- en laboratoriumdieren meestal een gecontroleerde voergift van 75 tot $80 \%$ t.o.v. de ad libitum voergift verstrekt ( 20 tot $25 \%$ voercontrole).

\section{Conclusies}

Uit het literatuuronderzoek kunnen de volgende conclusies getrokken worden:

- De reden van voercontrole bij vleeskuikenouderdieren komt door het verschil tussen de streefgewichten van vleeskuikens en vleeskuikenouderdieren op dezelfde leeftijd.

- Experimenten en berekeningen om een betrouwbaar niveau van voercontrole te bepalen moeten worden uitgevoerd bij vergelijkbare lichaamsgewichten en energieopname per dag.

- Uit berekeningen blijkt dat de gemiddelde energiecontrole bij vleeskuikenouderdieren tijdens de opfok- en legperiode respectievelijk $47 \%$ en $35 \%$ is. Doordat ouderdieren niet exact hetzelfde groeipotentieel en een 3\% lager borstvlees gehalte hebben, en door het heterosis effect bij de nakomelingen, is dit mogelijk een overschatting en zal de werkelijke controle lager zijn. In dit rapport is hiervoor een schatting gehanteerd van $10 \%$ wat de energiecontrole tijdens de opfok- en legperiode op $42 \%$ en $31 \%$ brengt. Dit is beduidend lager dan de 66 tot $75 \%$ en 20 tot $55 \%$ die in de literatuur wordt gehanteerd voor de opfok-en legperiode.

- Via factoriele berekeningen t.o.v. de energiebehoefte wordt de energiecontrole tijdens de opfok- en legperiode geschat op respectievelijk $12 \%$ en $3 \%$.

- Plasma corticosteron concentratie lijkt niet geschikt als welzijnsindicator terwijl hematologische metingen (verhouding heterofielen en basofielen t.o.v. lymfocyten) wel geschikt lijken.

- Stereotiep pikgedrag naar objecten en staartlikken lijken betrouwbare welzijnsindicatoren. Alhoewel het staartlikken ook te maken kan hebben met het opnemen van vet uit de stuitklier.

- Stereotiep pikken naar een ogenschijnlijk leeg voersysteem is mogelijk geen betrouwbare welzijnsindicator. Doordat de dieren op bijvoorbeeld de lege voerpan of aanvoervijzel pikken komt er mogelijk wat restvoer vrij dat werkt als een beloning voor het pikgedrag.

- Het pikken naar water en lopen voor het voeren zijn geen geschikte welzijnsindicatoren.

- Het stereotiep pikgedrag is een indicator van verminderd welzijn terwijl de voeropname motivatie van de dieren erg hoog is. Daarnaast is te beargumenteren dat het stereotiep pikgedrag mede ontstaat door een mismatch in tijdsbesteding doordat de dieren het voer te snel opnemen. Een combinatie van maatregelen om de voeropnametijd maximaal te verlengen om de gevolgen van voercontrole te verminderen, lijkt het meeste effect te genereren.

- Ad libitum voer verstrekken resulteert in nadelige effecten op gezondheid en reproductie. 
- Het inzetten van ouderdieren van trager groeiende rassen is geen goed alternatief voor voercontrole, doordat de brede duurzaamheid (People, Planet, Profit) hiermee in het gedrang komt.

- Het toevoegen van eetlustonderdrukkers zoals calciumpropionaat lijkt geen goede methode omdat de dieren zich mogelijk ziek voelen.

- In het algemeen lijkt afwijkend pikgedrag tijdens de opfokperiode vooral te maken hebben met tijdsbesteding en minder met honger en frustratie.

- Het vaststellen van de mate van honger bij vleeskuikenouderdieren kan alleen via een combinatie van indirecte observaties die niet altijd eenduidig zijn.

- De prevalentie van overgewicht en obesitas bij honden en katten wordt geschat op respectievelijk $40 \%$ en $32 \%$, en lijkt toe te nemen.

- Overgewicht bij laboratoriumdieren leidt tot negatieve effecten op gezondheid, welzijn en de uitkomsten van experimenten.

- Om overgewicht te voorkomen krijgen huis- en laboratoriumdieren meestal een gecontroleerde voergift van 75 tot $80 \%$ t.o.v. de ad libitum voergift verstrekt (20 tot $25 \%$ voercontrole).

Aanbevelingen

- Verschillende combinaties van maatregelen onderzoeken om de gevolgen van voercontrole te verminderen lijkt het meeste effect te genereren. Daarvoor wordt gedacht aan meerdere keren per dag voeren, verschillende methoden van voer verstrekken en verdund voer in combinatie met innovatieve oplossingen.

- Onderzoek verrichten naar het effect van gecontroleerd of ongecontroleerd water verstrekken tijdens de opfok- en legperiode op gedrag en fysiologische parameters.

- Experimenten uitvoeren om meer inzicht te krijgen in fysiologische indicatoren voor honger. Verder is meer onderzoek nodig naar betere testen om voeropnamemotivatie te meten. 


\section{$1 \quad$ Inleiding}

Voercontrole, met name tijdens de opfokperiode, bij vleeskuikenouderdieren is al jaren een controversieel onderwerp. Vermeerderaars, (gedrags)wetenschappers, fokkerijorganisaties en dierbelangenorganisaties verschillen hierover met elkaar van mening. Aan de ene kant gaan dierbelangenorganisaties ervan uit dat ouderdieren tijdens hun productieve leven continu in een staat van honger verkeren doordat er sprake is van een gecontroleerde voergift. Aan de andere kant beargumenteert de sector dat men de dieren gecontroleerd voert om problemen met gezondheid, welzijn en productie door een te hoog lichaamsgewicht te voorkomen. Daarom wordt in dit verband vaak gesproken over de "Broiler Breeder Paradox". Ad libitum voer verstrekken heeft negatieve gevolgen voor gezondheid, welzijn en (re)productie, maar aan de ander kant heeft de voercontrole ook negatieve effecten op gedrag en welzijn.

Voercontrole bij vleeskuikenouderdieren is ontstaan doordat de ouders van vleeskuikens opgefokt worden om eieren te leggen. Ouderdieren hebben min of meer hetzelfde potentieel om in korte tijd naar een hoog gewicht te groeien. Dit heeft consequenties voor de manier waarop deze dieren gehouden worden en dan met name de hoeveelheid voer die deze dieren krijgen. In het algemeen groeien vleeskuikens in 35 dagen naar een gewicht van 2,3 kilogram terwijl de ouderdieren dat gewicht moeten bereiken op 20 weken leeftijd. Dit impliceert dat deze dieren een kleinere gecontroleerde voerhoeveelheid krijgen om dat gewenste gewicht te bereiken. De gecontroleerde (kleine) hoeveelheid voer die de dieren tijdens de opfokperiode krijgen is meestal in een half uur opgenomen waardoor de dieren tijd over hebben voor andere gedragingen. Deze gedragingen zijn niet altijd positief, zoals stereotiep pikgedrag naar objecten en andere dieren.

Het doel van dit rapport is om de literatuur, data en beschikbare kennis over dit onderwerp te verzamelen om na te gaan wat er gevonden is in experimenten. Daarnaast wordt ook gekeken naar de voerprogramma's van huis- en laboratoriumdieren.

\section{Leeswijzer}

In hoofdstuk 2 wordt de vleeskuikenouderdieren sector beschreven met aandacht voor de ontwikkeling van de dieren, management en landgebruik. In hoofdstuk 3 wordt ingegaan op verschillende manieren om het niveau van de voercontrole te bepalen. In hoofdstuk 4 worden de effecten van voercontrole op fysiologie, gedrag en productie besproken. Hoofdstuk 5 wordt gebruikt om de mogelijkheden te onderzoeken om de effecten van voercontrole te verminderen. In hoofdstuk 6 wordt besproken hoe huis- en laboratoriumdieren gecontroleerd gevoerd worden. In hoofdstuk 7 wordt ingegaan op het onderwerp honger en dan met name over de methodiek om honger te meten. In hoofdstuk 8 volgen de conclusies. Per hoofdstuk wordt een samenvatting van de inhoud gegeven. 


\section{Vleeskuikenouderdieren}

\subsection{Beschrijving sector}

De vermeerderingssector, met zogenoemde vleeskuikenouderdieren, neemt binnen de pluimveevleesketen een belangrijke positie in (Figuur 1). Het uitgangsmateriaal (vleeskuikens) voor vleeskuikenhouders (via broedeieren en broederijen) in de keten wordt namelijk op deze bedrijven geproduceerd. De pluimveehouders die vleeskuikenouderdieren houden worden vermeerderaars genoemd.

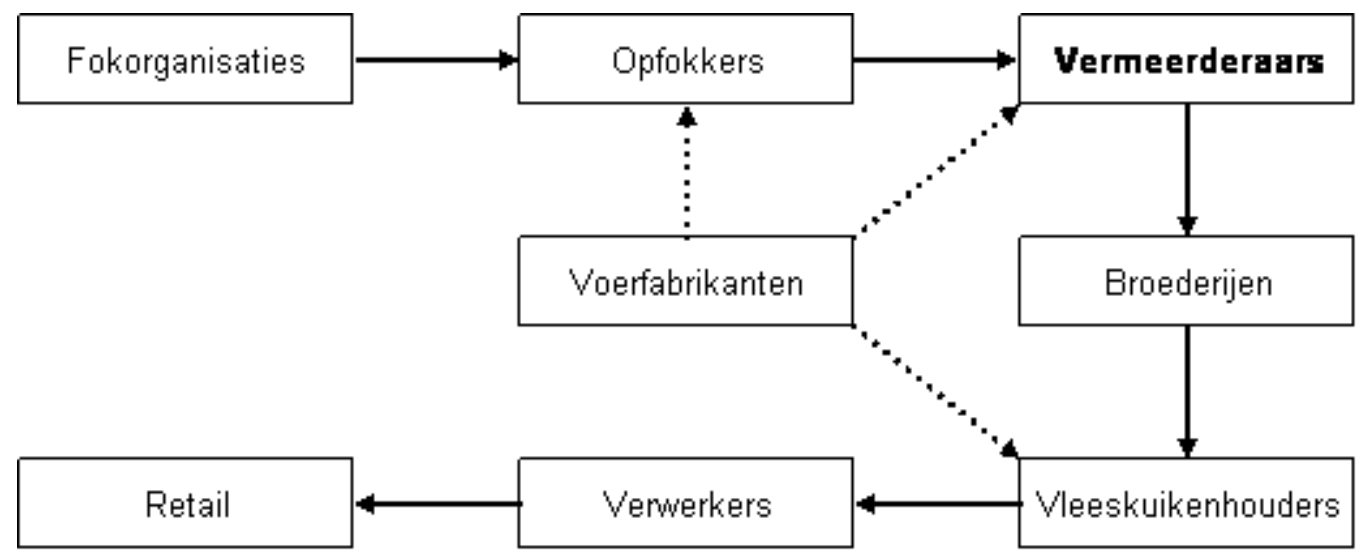

Figuur 1 Schematische weergave pluimveevleesketen

\section{Fokkerijorganisaties}

De fokkerijorganisaties zijn in de keten verantwoordelijk voor het fokken en selecteren van het uitgangsmateriaal (ouderdieren) voor de vermeerderingssector. Eind jaren dertig waren er in Nederland nog bijna 300 (kleine) fokbedrijven voor kippen (Ketelaars, 1992). Door fusies en overnames is het aantal fokorganisaties sinds die tijd drastisch afgenomen. Specifiek voor de vleeskuikens zijn er wereldwijd nog maar twee fokkerijorganisaties:

- $\quad$ Aviagen (USA) met de merken Ross 308, Ross 708, Indian River, Arbor Acres en Ranger Classic en Ranger Gold (trager groeiend vleeskuiken). Sinds 2019 is ook Hubbard (Fra), met o.a. de trager groeiende merken JA787 en JA757, onderdeel van Aviagen.

- Cobb-Vantress (USA) met de merken Cobb 500, Cobb 700, Sasso (trager groeiend vleeskuiken).

\section{Opfokbedrijven (opfokkers)}

De opfokbedrijven ontvangen eendagskuikens (hennen en hanen) van de fokorganisaties en verzorgen deze kuikens tot circa 20 weken leeftijd. Tijdens deze periode groeien de dieren van eendagskuiken naar een volwassen gewicht van circa 2,3 kilogram op 20 weken leeftijd waardoor ze klaar zijn om eieren te produceren. We noemen de dieren vleeskuikenouderdieren of moederdieren voor de hennen en vaderdieren voor de hanen. Belangrijk hierbij is dat de dieren gezond zijn, een goed gewicht en conditie hebben, gevaccineerd zijn en uniform zijn. Daarna worden de dieren aan de vermeerderingsbedrijven (productiebedrijven) geleverd. Doordat opfokbedrijven gespecialiseerde bedrijven zijn en eerste klas uitgangsmateriaal moeten leveren aan vermeerderingsbedrijven hebben deze bedrijven een hoog niveau van bio-security en ziektepreventie.

\section{Vermeerderingsbedrijven}

De ouderdieren op vermeerderingsbedrijven produceren zoveel mogelijk bevruchte $1^{\mathrm{e}}$ soort broedeieren van minimaal 50 gram (ondergrens broedeieren) die vervolgens uitgebroed worden door gespecialiseerde broederijen voor vleeskuikens. De vermeerderingsbedrijven produceren broedeieren voor de binnen- en buitenlandse markt. Het aantal vermeerderingsbedrijven in Nederland is sinds 2000 gehalveerd van 380 naar 190 bedrijven in 2018 (CBS, 2020). 
In dezelfde periode is het aantal ouderdieren licht gedaald van 5,4 naar 5,0 miljoen. In de laatste kleine 20 jaar is door schaalvergroting het aantal dieren per bedrijf echter gestegen van iets meer dan 10.000 naar bijna 25.000 (CBS, 2020). Schaalvergroting word aangestuurd door de vraag naar grotere uniforme partijen eendagskuikens vanuit de vleeskuikenhouderij (van Horne et al., 2004). Een belangrijk deel van de vermeerderingsbedrijven is gespecialiseerd, maar een klein deel van de productie vindt ook plaats op gemengde bedrijven. De vermeerderaars hebben over het algemeen contracten met broederijen voor een of meerdere rondes betreffende de afname van de broedeieren. Ongeveer 55\% van alle broedeieren is bestemd voor export naar Duitsland, België, Rusland, MiddenOosten en Afrika.

\section{Broederijen}

Broederijen nemen broedeieren af van de vermeerderingsbedrijven en broeden deze in 21 dagen uit tot eendagskuikens die aan de vleeskuikenbedrijven worden verkocht. In de afgelopen decennia is ook in deze ketenschakel sprake geweest van schaalvergroting; van de 46 broederijen van vleeskuikenrassen in 1990 in Nederland zijn er in 2020 nog circa 10 over. De binnenlandse vleeskuikenbedrijven worden vooral door de grote broederijen van dieren voorzien. De 5 grootste broederijen hebben samen $80 \%$ van de Nederlandse markt in handen De kleine broederijen die zich eveneens richten op de binnenlandse markt, hebben veelal vaste klanten (van Horne et al., 2004). Daarnaast zijn er gespecialiseerde broederijen die zich of voornamelijk richten op de exportmarkt of met name grootouderdieren broeden voor de fokorganisaties Aviagen en Cobb.

\section{Vleeskuikenbedrijven}

De vleeskuikenbedrijven nemen de eendagskuikens af van de broederijen om deze in 41 dagen te verzorgen tot een gewicht van $2,4 \mathrm{~kg}$ en leveren de kuikens dan aan de slachterij. Het aantal bedrijven met vleeskuikens is sinds 1985 eveneens gedaald. In 1985 waren nog 1.459 vleeskuikenbedrijven actief die iets meer dan 38 miljoen vleeskuikens hielden. In 2000 was dat aantal gestegen naar 51 miljoen vleeskuikens op 1.094 bedrijven (van Horne et al., 2004). Daarna is het aantal gedaald naar 42 miljoen in 2018 op 535 bedrijven (CBS, 2020). In deze schakel is dus ook sprake geweest van schaalvergroting en een stijging van de gemiddelde bedrijfsgrootte. Het gemiddeld aantal dieren per bedrijf is van 1985 tot 2000 bijna verdubbeld van 28.000 tot bijna 47.000 dieren. In 2018 was de gemiddelde bedrijfsgrootte verder gegroeid naar bijna 80.000 dieren. Nagenoeg alle in Nederland geproduceerde vleeskuikens worden ook in Nederland geslacht (Tacken et al., 2003). De meeste bedrijven werken dan ook op contract voor Nederlandse slachterijen.

\section{Verwerkers}

Aan het einde van de groeiperiode worden de levende vleeskuikens aan de verwerkers (slachterijen) geleverd die op hun beurt het pluimveevlees aan o.a. supermarkten leveren.

\subsection{Vleeskuiken versus leghen}

Voor 1900 waren kippen op de gemengde boerderij bijzaak, er waren maar enkele boerderijen die meer dan tien tot twintig kippen hielden (van der Waaij en Theunissen, 2017). De meest gebruikte rassen waren de Barnevelder, de Welsumer, de Witte Leghorn en de Amerikaanse Rhode Island Red (Knibbe, 1995). Deze oude rassen legden kleine eieren en werden aangemerkt als dubbeldoel dieren, dus na een productief leven werden ze geslacht voor het vlees. Vanaf ca. 1955 begonnen de fokkerijorganisaties zich te specialiseren in vlees- of legkippen waarbij ze overschakelden van zuivere lijnen naar kruisingsproducten van verschillende genetische lijnen (Figuur 2). Hiervoor werden verschillende oorspronkelijke zuivere kippenlijnen gebruikt die voor het ene doel geschikter waren dan voor het andere doel. Rond 1900 legden kippen gemiddeld 85 eieren per jaar, tegenwoordig zijn dat er bij leghennen meer dan 300 (Knibbe, 1995). Doordat leghennen steeds robuuster worden en langer worden aangehouden, produceren de dieren momenteel meer dan 400 eieren in hun productieve leven van circa 80 weken (Hyline, 2018; Lohmann, 2016; Novogen, 2017). De verwachting is dat dit aantal zal toenemen tot boven de 500 eieren in ongeveer 100 weken (Molnár et al., 2018).

Vleeskuikens maakten in diezelfde periode ook een enorme ontwikkeling door naar een veel snellere groei en zeer efficiënte omzetting van voer naar vlees. Kuikens bereikten in 1925 een lichaamsgewicht van 1.500 gram in 120 dagen terwijl dat gewicht in 1995 in 33 dagen werd bereikt (Albers, 1998). 
Een ander onderzoek liet zien dat kuikens in 1950 nog 84 dagen nodig hadden om een gewicht van 1.800 gram te bereiken terwijl ze dit gewicht in 2010 al in 33 dagen bereikten ( $R$. Gous, persoonlijke mededeling). De groei werd ook veel efficiënter, uitgedrukt in hoeveelheid voer per $\mathrm{kg}$ groei (= voederconversie) en ging in dezelfde periode (1950 tot 2010) van 3,25 naar 1,50 kg voer per $\mathrm{kg}$ groei. Het modernste vleeskuiken bereikt $1.800 \mathrm{gram}$ in 30 dagen bij een voederconversie van 1,38. Bij deze toename speelden wetenschappelijk-technologische ontwikkelingen op het gebied van voeding, huisvesting, ziektebestrijding en fokkerij een centrale rol (van der Waaij en Theunissen, 2017). Wanneer het huidige vleeskuiken (Figuur 2 links) vergeleken wordt met een leghen (Figuur 2 rechts), zoals de Lohmann LSL-Classic, is goed te zien dat er grote, fysieke verschillen zijn tussen deze twee rassen. Naast de fysieke verschillen zijn er ook verschillen in voederconversie (ca. 1,5 bij vleeskuikens vs. 2,0 bij leghennen) en lichaamsgewicht: toename van ca. $2.500 \mathrm{~g}$ over 42 dagen bij vleeskuikens vs. 1.700 tot $1.900 \mathrm{~g}$ over 540 dagen bij leghennen.
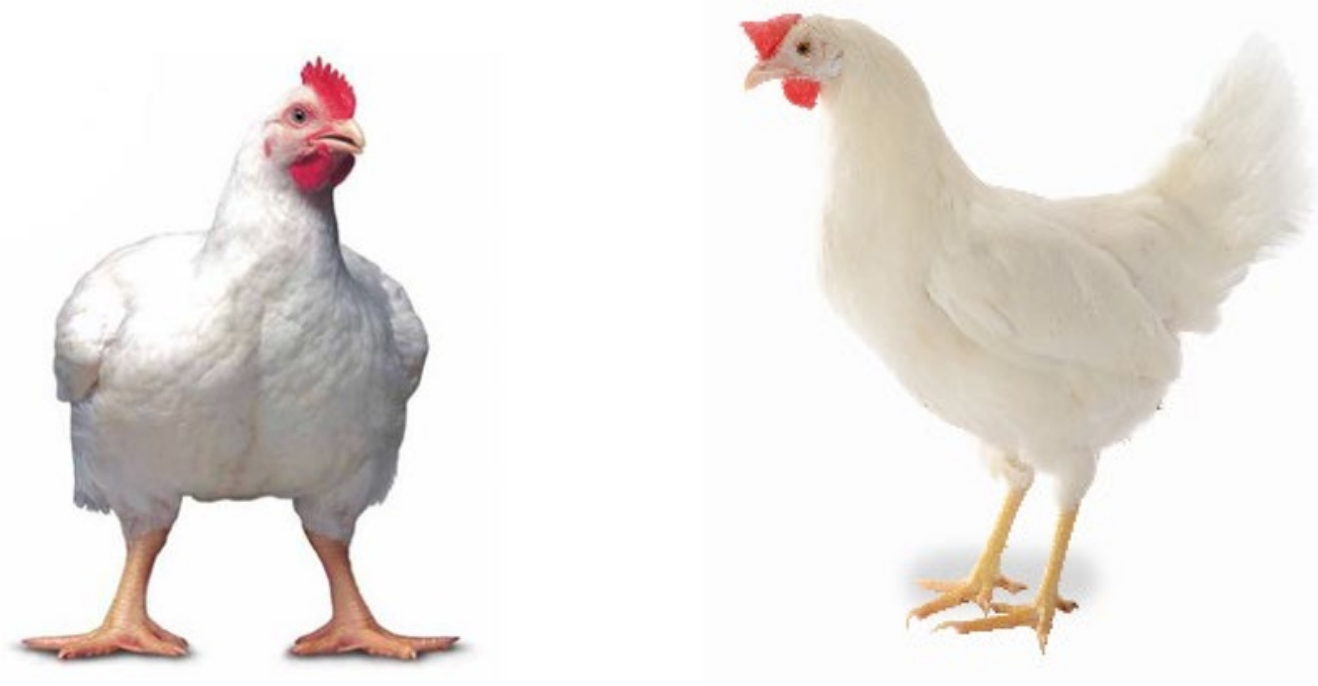

Figuur 2 Afbeelding van een Ross 308 vleeskuiken van 6 weken leeftijd (links) en een Lohmann LSL-Classic leghen van 18 weken leeftijd (rechts).

In de pluimveevleesketen gebruikte men voorheen voornamelijk snelgroeiende rassen, zoals de Ross 308 , de Cobb 500 of de Hubbard Flex. Deze reguliere of conventionele rassen worden gehouden tot een gemiddeld van 2,4 kilogram, 41 dagen bij maximaal $42 \mathrm{~kg} / \mathrm{m}^{2}$ (KWIN, 2021). Door de toenemende discussie over het welzijn van vleeskuikens, is in de afgelopen vijf jaar de consumptie en productie van trager groeiende kuikens (TGK) in Nederland sterk toegenomen. Dit zijn de:

- Kip van Morgen (concept kuikens): 50 gram/dag, 49 dagen en max 38 kg/m² (Hubbard JA787, Ranger Classic)

- Beter Leven 1 ster: 45 gram/dag, 56 dagen en max 25 kg/m² (Hubbard JA757, Ranger Gold) Eind 2017 was ca. $90 \%$ van al het verse pluimveevlees in de Nederlandse supermarkten afkomstig van trager groeiende vleeskuikens (met name van Kip van Morgen) wat overeen komt met ca. 30\% van de totale Nederlandse productiecapaciteit (P. van Boekholt, persoonlijke mededeling). Ongeveer $85 \%$ van de trager groeiende vleeskuikens bestaan uit zogenaamde conceptkuikens (Hubbard JA787 en Ranger Classic) en 15\% uit Beter Leven 1 ster kuikens (Hubbard JA757 en Ranger Gold). De resterende $70 \%$ van het pluimveevlees dat in Nederland wordt geproduceerd bestaat uit snelgroeiende vleeskuikens ( $98 \%$ Ross 308 en $2 \%$ Cobb 500) die voor een groot gedeelte bestemd zijn voor de export.

\subsection{Ontwikkeling vleeskuiken}

Tientallen jaren van intensieve genetische selectie hebben vleeskuikens het potentieel gegeven voor efficiënte groei. Om dit potentieel door te geven, hebben vleeskuikenouderdieren min of meer dezelfde genetische groeipotentie als de vleeskuikens (Havenstein et al., 2003a,b; Renema et al., 2007; Zuidhof et al., 2014). In onderzoek van Havenstein et al. (2003a,b) werden vleeskuikens uit 1957 en 2001 gebruikt. 
Het ras uit 1957 heeft sinds dat jaar geen genetische ontwikkeling meer doorgemaakt en wordt in stand gehouden door inteeltkruisingen. Beide rassen (1957 en 2001) kregen voeders verstrekt gebaseerd op de voersamenstellingen uit 1957 en 2001 (in een 2x2 opzet). In de eerste plaats zagen zij een enorm verschil in groeisnelheid tussen beide soorten kuikens. De vleeskuikens uit 2001 (Ross 308) bereikten op 42, 56, 70 en 84 dagen leeftijd een respectievelijk gemiddeld 4,3, 4,1, 3,7 en 3,3 maal hoger gewicht dan de kuikens uit 1957 (Figuur 3). Zij toonden verder aan dat de gewichtstoename van de vleeskuikens uit 2001 t.o.v. 1957 voor 85 tot $90 \%$ te danken is aan de genetische vooruitgang en slechts $10-15 \%$ door aanpassingen aan het voer. Het voeren van een modern rantsoen (2001) aan het ras uit 1957 gaf geen verschil in vergelijking met het 1957 rantsoen. Het verstrekken van een modern rantsoen aan het 2001 ras liet echter wel een verbeterde groei zien ten opzichten van het 1957 rantsoen.

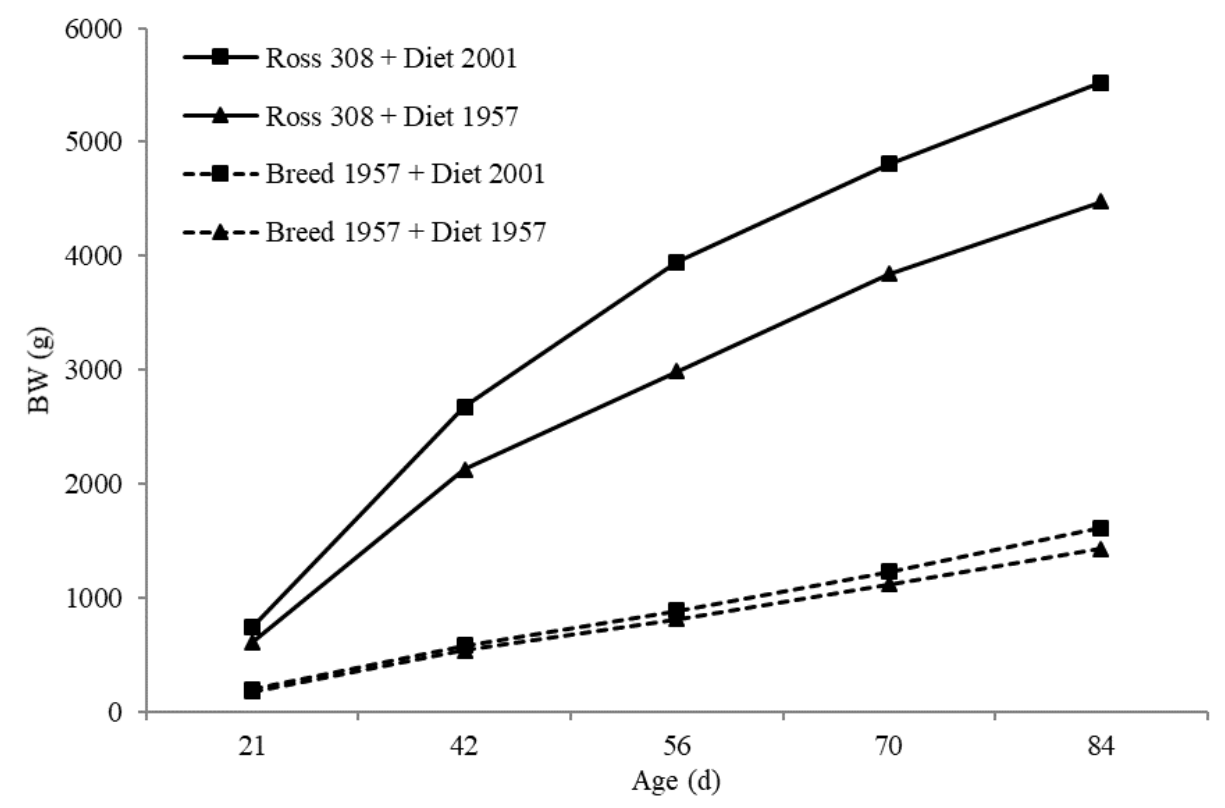

Figuur 3 Effect van merk (vleeskuiken 1957 en Ross 308) en voersamenstelling (voer 1957 en 2001) op de gewichtsontwikkeling (Havenstein et al., 2003a).

Het groeipotentieel van de vleeskuikens heeft ook grote gevolgen voor de efficiëntie (voederconversie) van de dieren (Havenstein et al., 2003a; Zuidhof et al., 2014). In tabel 1 zijn de resultaten weergegeven van de studie van Havenstein et al. (2003a). Vleeskuikens uit 1957 hadden bij een voer uit 1957 een voederconversie van 2,34 op 42 dagen leeftijd, terwijl de vleeskuikens uit 2001 (met 2001 voer) een voederconversie hadden van 1,63. Dit is een verbetering van de efficiëntie van $30 \%$ over 44 jaar met dus een gemiddelde verbetering van 0,7\% per jaar.

Tabel 1 Voederconversie ( $k g$ voer/kg groei) van vleeskuiken uit 1957 en 2001 (Ross 308) op verschillende leeftijden (Havenstein et al., 2003a).

\begin{tabular}{lccccccc} 
Merk kuiken & Voer & $0-21 d$ & $0-42 d$ & $0-56 d$ & $0-70 d$ & $0-84 d$ \\
Ross 308 & 2001 & 1,32 & 1,63 & 1,96 & 2,26 & 2,72 \\
\hline Ross 308 & 1957 & 1,53 & 1,92 & 2,35 & 2,62 & 3,29 \\
\hline Ras 1957 & 2001 & 1,82 & 2,14 & 2,35 & 3,06 & 3,32 \\
\hline Ras 1957 & 1957 & 1,81 & 2,34 & 2,54 & 3,36 & 3,84 \\
\hline
\end{tabular}

Het effect van genetische vooruitgang op efficiëntie (voederconversie) is ook gebleken in het onderzoek van Zuidhof et al. (2014). De vleeskuikens uit 1957, 1978 en 2005 hadden een cumulatieve voederconversie op 42 dagen van respectievelijk 2,88, 1,90 en 1,67. Dit is een verbetering van de efficiëntie van respectievelijk 34\% (kuiken 1978 vs. 1957) en 42\% (kuiken 2005 vs. 1957). Tussen 1957 en 2005 verbeterde de voederconversie met 0,9\% per jaar. 
Naast de verbetering van de groeisnelheid en voederconversie van vleeskuikens is de vorm van de dieren ook enorm veranderd (Figuur 4). Vleeskuikens van 60 jaar geleden groeiden uit tot ranke kuikens terwijl de huidige vleeskuikens een veel breder voorkomen hebben.

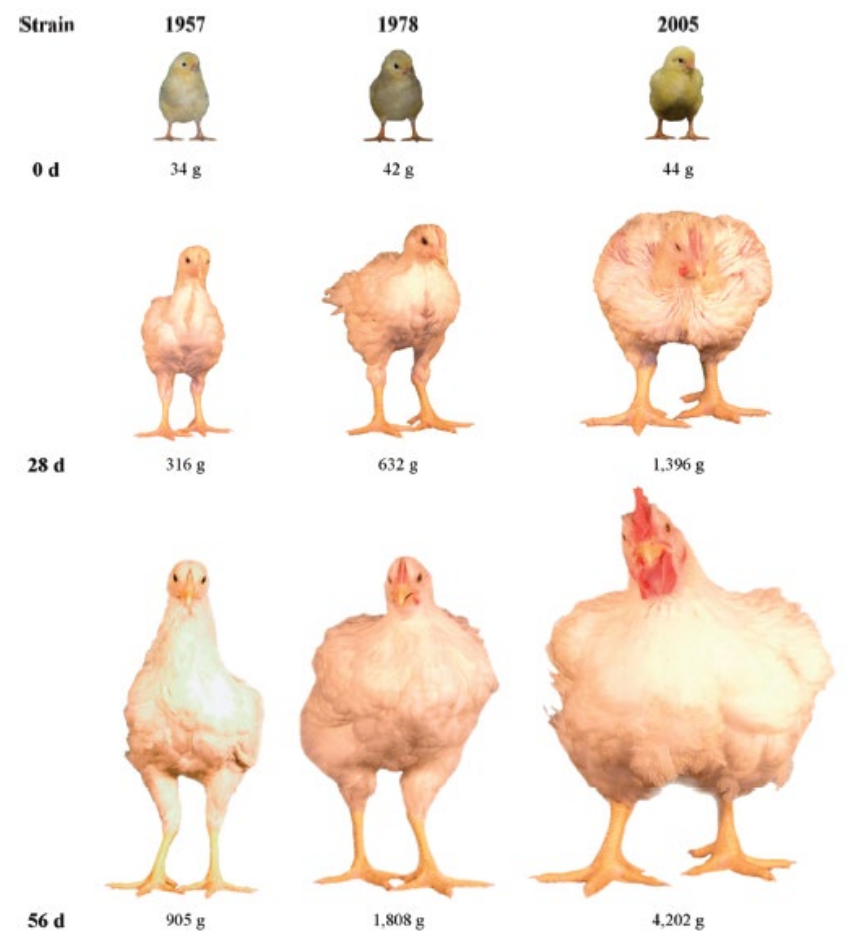

Figuur 4 Vorm van vleeskuikens uit 1957, 1978 en 2005 (Ross 308) op verschillende leeftijden (Zuidhof et al., 2014).

De veranderde vorm van de dieren is vooral veroorzaakt door het aandeel borstfilet van de moderne kuikens wat in het figuur goed tot uitdrukking komt. Dit beeld wordt bevestigd in de analyse van de lichaamssamenstelling van de vleeskuikens die de laatste decennia sterk is veranderd. Uit onderzoek van de Beer (2009) blijkt dat het aandeel borstfilet van vleeskuikens uit 1972 en 2005 met 8,7 procentpunt (van 17,3 naar $26,0 \%$ ) is toegenomen terwijl het aandeel vet juist een omgekeerde trend liet zien (Figuur 5). Het aandeel abdominaal vet (in de buikholte) is gehalveerd (van 3,8 naar 1,9\%) en het totale aandeel vet in het dier is afgenomen met 7,1 procentpunt (van 20,7 naar 13,6\%). Dit verklaart meteen een groot gedeelte van de verlaging van de voederconversie omdat de aanzet van eiwit veel efficiënter is dan de aanzet van vet, waardoor de dieren hetzelfde gewicht bereiken met minder voer.

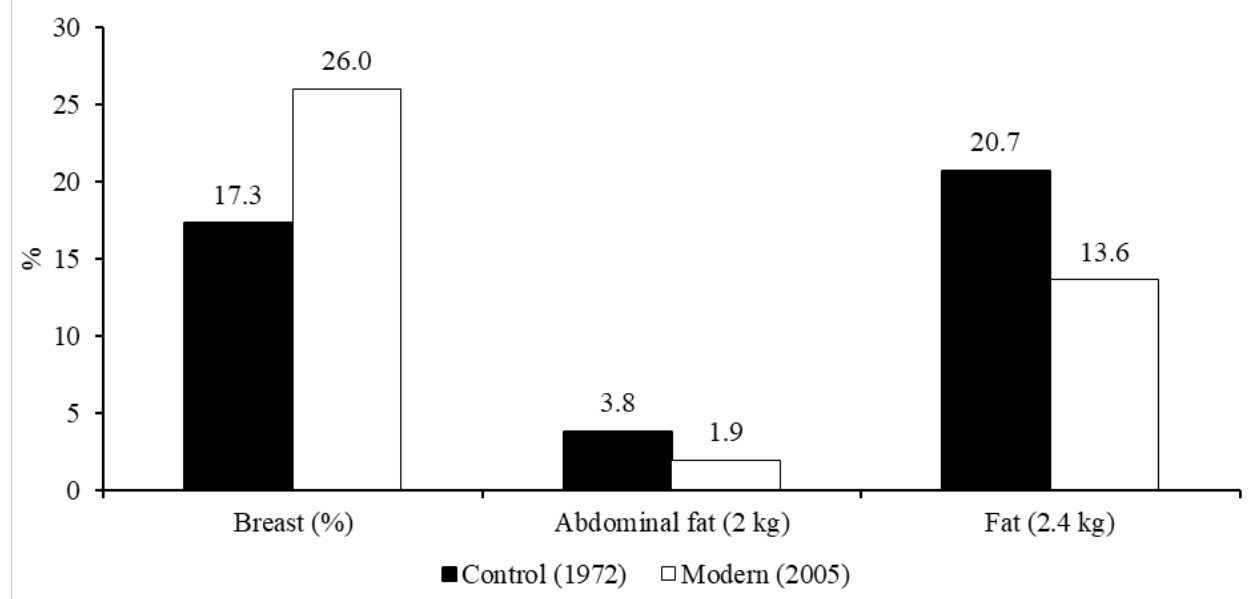

Figuur 5 Lichaamssamenstelling van vleeskuikens uit 1972 en 2005 (Ross 308) (de Beer et al., 2009).

De verandering in lichaamssamenstelling van vleeskuikens is ook terug te zien bij de vleeskuikenouderdieren. Onderzoek van Eitan et al. (2014) met circa 30 weekse ouderdieren rassen uit 1980 en 2000 laat zien dat het borstfilet (breast) in 20 jaar met ruim 6 procentpunt (van 15,0 naar 
$21,3 \%$ ) is toegenomen (Figuur 6). Het vetgehalte is afgenomen wat zichtbaar is in het aandeel buikvet (fat pad) dat in diezelfde periode halveerde van 5,37 naar 2,67\%.

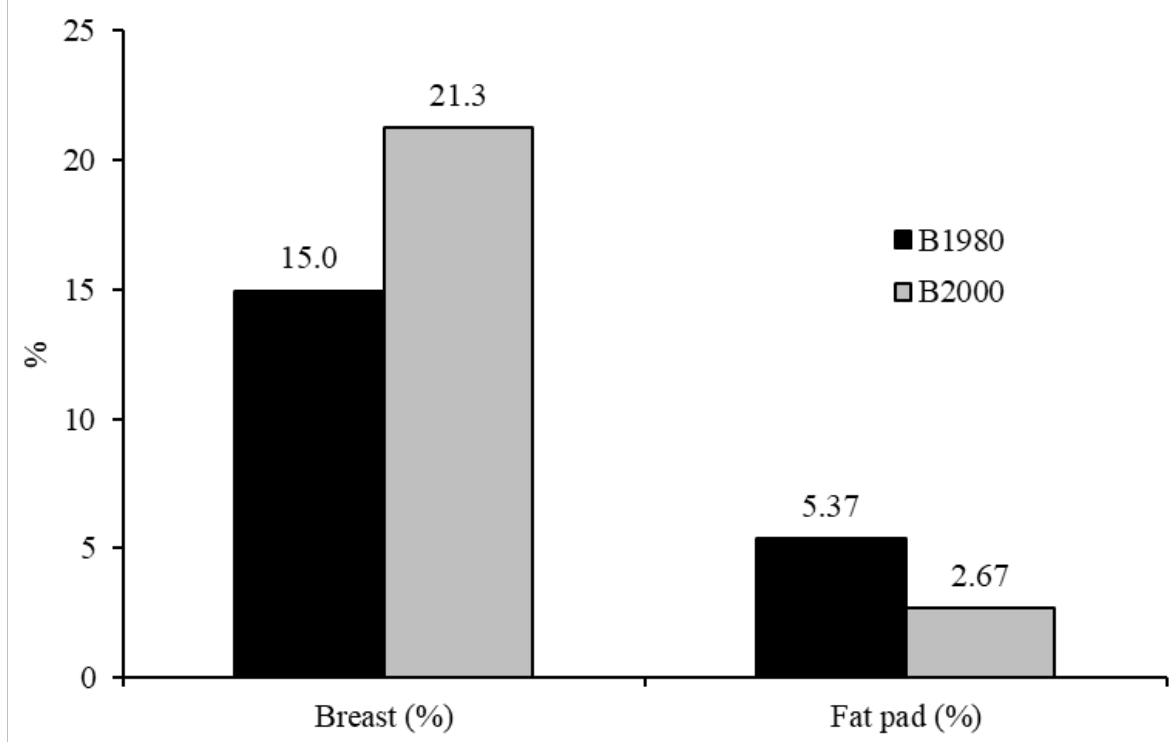

Figuur 6 Lichaamssamenstelling van vleeskuikenouderdieren uit 1980 (B1980) en 2000 (B2000) (Eitan et al., 2014).

\subsection{Effect efficiëntie vleeskuiken op landgebruik}

\section{Snelgroeiende vleeskuikens}

Het effect van de toegenomen efficiëntie (lagere voederconversie: kg voer/kg groei) van vleeskuikens op het landgebruik is groot. De jaarlijkse vooruitgang op voederconversie is door Neeteson et al. (2013) en Fancher (2014) berekend op respectievelijk 0,015 en 0,018 per jaar.

Voor de berekeningen naar het effect van de lagere voederconversie op de jaarlijkse besparing op het wereld landgebruik zijn diverse uitgangspunten geformuleerd op basis van de literatuur. In Nederland worden per jaar 360 miljoen vleeskuikens opgezet, verdeeld in $70 \%$ reguliere en $30 \%$ trager groeiende vleeskuikens (Agrimatie, 2020). Daarom is voor Nederland gerekend met 250 miljoen reguliere vleeskuikens per jaar. Voor de voederconversie voor Nederland, Europa en de wereld is uitgegaan van respectievelijk 1,60, 1,70 en 1,80 (A. Neeteson, persoonlijke mededeling). De jaarlijkse vooruitgang op voederconversie is conservatief ingeschat op 1,5 punt (Neeteson et al., 2013). Er is een inschatting gemaakt voor de gemiddelde samenstelling van het voer (vanuit internationale praktijkdata) en de opbrengst per hectare van de belangrijkste ingrediënten tarwe, mais en soja(schroot) (FAO, 2020). Wereldwijd verschilt de voersamenstelling, in Europa is het hoofdaandeel tarwe, terwijl in de Verenigde Staten mais het hoofdbestanddeel is. Daarnaast worden ingrediënten over de hele wereld geproduceerd en getransporteerd. Voor de opbrengst per hectare van tarwe voor Nederland, Europa en de wereld is uitgegaan van de opbrengst in Nederland, Europa en de wereld. Omdat mais grotendeels geïmporteerd wordt, is voor Nederland uitgegaan van de opbrengt per ha in Europa. Voor Europa en de wereld is voor mais uitgegaan van de opbrengst in Europa en de wereld. Verder maken alle landen gebruik van een flink aandeel soja(schroot). Via de verschillende geschatte samenstellingen van voeders en opbrengst per hectare is een gewogen gemiddelde voor de opbrengst per hectare berekend. Voor Nederland, de EU en de wereld komt die op respectievelijk $6,61,5,13$ en 4,66 ton per ha.

Voor Nederland is gerekend met 600 miljoen $\mathrm{kg}$ reguliere vleeskuikens ( 250 miljoen kuikens $\times 2,4 \mathrm{~kg}$ ) per jaar. Een vooruitgang in voederconversie van 1,5 punt betekent een besparing van 9.000 ton voer. Bij een gemiddelde opbrengst per hectare van 6,61 geeft dit een besparing van 1.360 hectare per jaar (Tabel 2). Een zelfde berekening is uitgevoerd voor Europa en voor de wereld met de bijbehorende getallen voor aantal vleeskuikens en opbrengst per ha. Uit de berekeningen blijkt dat dit 
voor Europa en de wereld resulteert in een lager (wereld)landgebruik van respectievelijk 44.000 en 610.200 ha per jaar. Dat laatste is vergelijkbaar met de oppervlakte van de provincies Friesland en Groningen of een derde deel van het areaal landbouwgrond in Nederland.

Tabel 2 Effect van de genetische vooruitgang op voederconversie (1,5 punt per jaar) op de besparing van het jaarlijkse (wereld)landgebruik. ${ }^{1}$

\begin{tabular}{lccc} 
& NL & EU-27 & Wereld \\
Aantal kuikens/jaar (miljoen stuks) & 250 & 6.275 & 79.000 \\
\hline Vleeskuikenvlees (miljoen kg) & 600 & 15.060 & 189.480 \\
\hline Voederconversie (kg voer/kg vlees) & 1,60 & 1,70 & 1,80 \\
\hline Besparing voer (ton/jaar) & 9.000 & 225.900 & 2.842 .000 \\
\hline $\begin{array}{l}\text { Besparing (wereld)landgebruik } \\
\text { (ha/jaar) }\end{array}$ & 1.360 & 44.000 & 610.200 \\
\end{tabular}

Neeteson et al. (2103) en Fancher (2014) schatten in dat per ton pluimveevlees de jaarlijkse besparing op landgebruik $1 \%$ is. Goed om te vermelden dat deze verbetering jaarlijks optreedt en daarmee in 10 jaar cumuleert naar een veel grotere besparing op het landgebruik. Dit is ook nodig om de snel stijgende wereldbevolking naar 10 miljard in 2050 (UN, 2019) en daarmee gepaard gaande vraag naar pluimveevlees voor te blijven.

\section{Trager groeiende vleeskuikens}

Circa 7 jaar geleden bestond de pluimveevleesketen in Nederland voor $98 \%$ uit reguliere (snelgroeiende) rassen (Ross en Cobb). Door de toenemende discussie over het welzijn van vleeskuikens, is de consumptie en productie van trager groeiende vleeskuikens (TGK) sterk toegenomen. In Nederland bestaat momenteel circa 30\% (circa 110 miljoen kuikens/jaar) van de totale vleeskuikenproductie uit TGK. Vanuit onderzoek is bekend dat TGK ten opzichte van reguliere vleeskuikens voordelen hebben op dierenwelzijn en gezondheid. TGK kuikens vertonen minder mobiliteitsproblemen, vertonen minder voetzoollaesies, hebben minder uitval en een lager antibioticagebruik. Er zijn echter ook een aantal knelpunten bij TGK, zoals uitstoot van schadelijke stoffen ( $\mathrm{NH}_{3}$, fijn stof) en diergezondheid (terugkeer ouderwetse ziekten zoals Marek en Gumboro). Het belangrijkste nadeel voor duurzaamheid is de hogere voederconversie en dus groter verbruik van grondstoffen voor voeders, en dus landbouwgrond. De grondstoffen voor vleeskuikenvoeders worden wereldwijd verbouwd, waardoor de omschakeling een wereldwijd effect heeft.

Om zich in de markt te profileren heeft elke supermarktketen zijn eigen concept ontwikkeld. Deze verschillende concepten hebben hun eigen specifieke richtlijnen op het gebied van groeisnelheid, bezetting, daglicht en verrijking in de stal (o.a. balen en bijstrooien graan). Al deze concepten richten zich op traag groeiende rassen. Enkele voorbeelden van de supermarkt concepten zijn de Goed Nest Kip van Albert Heijn, de Nieuwe Standaard Kip van Jumbo, de Langzaam Groeiende Kuikens van Aldi, etc. In het algemeen mogen de vleeskuikens binnen de concepten gemiddeld 45 tot 50 gram per dag groeien en is de bezetting (tussen 30 en $38 \mathrm{~kg} / \mathrm{m}^{2}$ ) wat lager dan bij reguliere kuikens. Verder is daglicht ( $3 \%$ staloppervlakte) vaak verplicht, is een minimale aaneengesloten donkerperiode van 6 uur voorgeschreven en hebben de dieren de beschikking over verrijkingen (bijv. pikstenen, balen (stro, hooi, mais of luzerne), strooien van graan, plateaus). Het Beter Leven 1 ster keurmerk (keurmerk van de Dierenbescherming) kenmerkt zich door aanvullende richtlijnen op het gebied van welzijn. Naast de voorgaande richtlijnen bevat het keurmerk regels over een kortere transportduur en toegang tot een overdekte uitloop. Vanaf 2019 wordt in de supermarkten uitsluitend vers pluimveevlees aangeboden afkomstig van het eigen concept, Beter Leven 1 ster kip of biologisch. Ruwweg bestaat momenteel het aanbod in de supermarkten uit: circa $85 \%$ concepten, $15 \%$ Beter Leven 1 ster en minder dan 1\% biologisch. Voor dit totale aanbod worden dus geen snelgroeiende vleeskuikens (zoals Ross 308 en Cobb 500) gebruikt. Voor de concept kuikens worden de rassen Hubbard JA787 en Ranger Classic gebruikt en wordt de Hubbard JA757 en Ranger Gold voor Beter Leven 1 ster kuikens gebruikt.

Tabel 3 laat de uitgangspunten en berekeningen zien die gebruikt zijn voor de berekening. Daarbij is uitgegaan van een vleeskuiken productiecapaciteit in Nederland van 360 miljoen kuikens per jaar 
(cijfers via www.agrimatie.nl). Daarvan bestaat 30\% (110 miljoen) uit TGK en $70 \%$ (250 miljoen) uit reguliere vleeskuikens. De TGK bestaat uit ca. 85\% (95 miljoen) concept kuikens en ca. 15\% (15 miljoen) Beter Leven 1 ster kuikens. Deze aantallen zijn gebruikt om het wereldwijde landgebruik te berekenen door 110 miljoen reguliere vleeskuikens te vervangen door trager groeiende vleeskuikens. Om het verschil aan te duiden, geven de berekeningen de scenario's weer van het voer- en landgebruik als deze 110 miljoen kuikens van reguliere of traag groeiende oorsprong zijn. De voederconversie is gebaseerd op KWIN (2021) die respectievelijk 1,60, 1,90 en 2,10 geeft voor reguliere, concept en Beter Leven 1 ster kuikens. $\mathrm{Er}$ is gerekend met eenzelfde eindgewicht van 2,4 kg voor reguliere, concept en Beter Leven 1 ster kuikens, afgeleverd op respectievelijk 41, 49 en 56 dagen leeftijd. Daarnaast is uitgegaan van een gemiddelde oogst opbrengst (tarwe, mais en sojaschroot) per hectare van 6,61 ton (FAO).

Uit de berekeningen blijkt dat het voerverbruik in Nederland met 86.400 ton per jaar $(20,5 \%)$ is toegenomen. Dit komt overeen met een toename van het wereldwijde landgebruik met 13.079 hectare. Dit is volledig toe te schrijven aan de lagere groei efficiëntie en de verhoogde activiteit van de TGK t.o.v. reguliere vleeskuikens. Dit zorgt ervoor dat de kuikens meer voer verbruiken en een groter aandeel van de energie uit het voer verbruikt wordt aan andere zaken dan aanzet van vlees. Dit tezamen resulteert in de 20 tot 30\% hogere voederconversie voor de TGK t.o.v. de reguliere kuikens.

Tabel 3 Uitgangspunten en berekeningen voor de vergelijking van de vervanging van reguliere door trager groeiende vleeskuikens (concepten en Beter Leven 1 ster) op het wereldwijde landgebruik.

\begin{tabular}{|c|c|c|c|c|}
\hline & \multirow{2}{*}{$\begin{array}{c}\text { Reguliere } \\
\text { kuikens }\end{array}$} & \multicolumn{3}{|c|}{ Trager groeiend kuikens } \\
\hline & & Totaal & Concepten & $\begin{array}{c}\text { Beter Leven } 1 \\
\text { ster }\end{array}$ \\
\hline \multicolumn{5}{|l|}{ Uitgangspunten } \\
\hline Aantal kuikens (miljoen/jaar) & 110 & & 95 & 15 \\
\hline Voederconversie $^{1}$ & 1,60 & & 1,90 & 2,10 \\
\hline \multicolumn{5}{|l|}{ Berekeningen } \\
\hline Voerverbruik (ton/jaar) & 422.400 & 508.800 & 433.200 & 75.600 \\
\hline Wereld landgebruik/jaar (ha) ${ }^{2}$ & 63.943 & 77.022 & 65.578 & 11.444 \\
\hline \multicolumn{5}{|l|}{ Toename } \\
\hline Voerverbruik (ton/jaar) & \multicolumn{2}{|c|}{+86.400} & & \\
\hline Wereld landgebruik/jaar (ha) & \multicolumn{2}{|c|}{+13.079} & & \\
\hline
\end{tabular}

\subsection{Huisvesting en management opfokperiode}

In de opfokperiode die tussen 0 en 18 tot 22 weken leeftijd plaatsvindt, worden vleeskuikenouderdieren voorbereid op de productiefase. Het doel van de opfokperiode is het produceren van ouderdieren met een ideaal gewicht, uniformiteit, conditie en stadium van seksuele volwassenheid wanneer ze naar de productiestallen gaan (Leeson en Summers, 2000).

Lichaamsgewicht en uniformiteit van het koppel zijn de belangrijkste productie-indicatoren tijdens de opfokperiode (Zuidhof et al., 2015).

Tijdens de opfokperiode worden vleeskuikenouderdieren gehuisvest op een vloer volledig bedekt met strooisel (meestal houtkrullen). Het voer wordt gedistribueerd via sleepketting, voerpannen of spinfeeders (systemen die het voer over het strooisel verspreiden) en kunnen worden verstrekt als meel, kruimel of pellet (specifiek bij spinfeeders). Tijdens de opfokperiode krijgen de dieren een gecontroleerde hoeveelheid voer (de Jong en Guémené, 2011; EFSA, 2010) en water (Hocking et al., 1993; de Jong et al., 2016) verstrekt. De dieren krijgen tijdens de opfokperiode in Nederland dagelijks voer verstrekt, aangezien de wetgeving geen voerloze dagen toestaat. In Nederland zijn de stallen uitgerust met moderne, snelle voersystemen waardoor alle dieren binnen drie minuten de beschikking hebben over voer. Ondanks de beschikbare moderne voersystemen wordt in het buitenland nog steeds veel gebruik gemaakt van voerprogramma's waarbij de dieren op bepaalde dagen geen voer krijgen. Dit betekent dat $80 \%$ van de ouderdieren (buiten Europa) volgens deze methode gevoerd wordt. 
Dit wordt veroorzaakt door onder andere verouderde voersystemen waarbij het voer niet in korte tijd egaal door de stal verspreid kan worden. Hierdoor ontstaan er, bij dagelijkse kleine porties voer, grote verschillen in uniformiteit wat voor een goed management tijdens de legperiode ongewenst is. Om de uniformiteit te verbeteren wordt daarom van oudsher een voerloze dag in het voerprogramma opgenomen. Bij voerprogramma's wordt gebruik gemaakt van skip-a-day (om de dag een dag zonder voer), skip-another-day (om de twee dagen een dag zonder voer) of 6/1,5/2 of 4/3 schema's (1, 2 of 3 dagen geen voer per week). Tijdens de resterende voerdagen krijgen de dieren dus een grotere portie. Onderzoek van de Beer en Coon (2007), Zuidhof et al. (2015) en Montiel (2016) geven echter nieuwe inzichten op de effecten van dagelijkse voeding. De Beer en Coon (2007) vergeleken vier verschillende voerprogramma's (skip-a-day, 4/3, 5/2 en dagelijks). Zij concludeerden dat dagelijkse gevoerde dieren tijdens de opfok $8 \%$ minder voer nodig hadden om hetzelfde lichaamsgewicht en moment van seksuele volwassenheid te bereiken. De dieren die tijdens de opfokperiode iedere dag voer kregen hadden een hogere eiproductie (totaal en $1^{\mathrm{e}}$ soort eieren) dan de dieren die via het 4-3 programma gevoerd werden (Tabel 4).

Tabel 4 Effect van verschillende voerprogramma's op diverse parameters (de Beer en Coon, 2007). ${ }^{1}$

\begin{tabular}{|c|c|c|c|c|}
\hline \multirow[b]{2}{*}{ Variable } & \multicolumn{4}{|c|}{ Feeding regimen ${ }^{3}$} \\
\hline & ED & SK & $4-3$ & $5-2$ \\
\hline Age at $\mathrm{SM}^{4}(\mathrm{~d})$ & $177.5 \pm 8.1^{\mathrm{b}}$ & $178.5 \pm 7.1^{\mathrm{b}}$ & $183.5 \pm 6.3^{\mathrm{a}}$ & $179.4 \pm 4.6^{\mathrm{b}}$ \\
\hline Peak egg production (\%) & $83.5 \pm 1.9$ & $81.9 \pm 1.6$ & $79.6 \pm 1.7$ & $83.0 \pm 1.5$ \\
\hline Age at peak egg production (d) & 210 & 212 & 215 & 212 \\
\hline Total eggs/hen & $97.4 \pm 2.0^{\mathrm{a}}$ & $93.4 \pm 2.6^{\mathrm{ab}}$ & $91.1 \pm 2.7^{\mathrm{b}}$ & $95.2 \pm 2.0^{\mathrm{a}}$ \\
\hline Settable eggs $/$ hen $^{5}$ & $93.6 \pm 1.9^{\mathrm{a}}$ & $89.6 \pm 2.5^{\mathrm{ab}}$ & $87.1 \pm 2.6^{\mathrm{b}}$ & $91.4 \pm 2.0^{\mathrm{a}}$ \\
\hline Abnormal eggs/hen ${ }^{6}$ & $1.4 \pm 0.2$ & $1.5 \pm 0.2$ & $1.7 \pm 0.2$ & $1.5 \pm 0.2$ \\
\hline First $3 \mathrm{EW}^{7}(\mathrm{~g})$ & $49.2 \pm 0.6$ & $49.9 \pm 0.5$ & $49.6 \pm 0.5$ & $49.8 \pm 0.5$ \\
\hline EW $(\mathrm{g})$ & $60.6 \pm 0.2^{\mathrm{b}}$ & $60.9 \pm 0.1^{\mathrm{b}}$ & $61.1 \pm 0.2^{\mathrm{ab}}$ & $61.7 \pm 0.2^{\mathrm{a}}$ \\
\hline Relative $\mathrm{EW}^{8}$ & $2.15 \pm 0.03^{\mathrm{b}}$ & $2.23 \pm 0.03^{\mathrm{ab}}$ & $2.23 \pm 0.03^{\mathrm{ab}}$ & $2.25 \pm 0.03^{\mathrm{a}}$ \\
\hline Fertility $^{9}(\%)$ & $65.3 \pm 3.3$ & $60.3 \pm 3.6$ & $64.8 \pm 3.4$ & $60.4 \pm 3.8$ \\
\hline Hatch of fertile (\%) & $88.6 \pm 2.3$ & $85.4 \pm 4.2$ & $91.5 \pm 2.8$ & $90.1 \pm 2.7$ \\
\hline
\end{tabular}

${ }^{1} \mathrm{ED}=$ iedere dag voer, $\mathrm{SK}=$ skip-a-day, 4-3 = 4 dagen voer +3 voerloze dagen per week; 5-2 = 5 dagen voer +2 voerloze dagen per week.

Onderzoek van Montiel (2016) bevestigt de eerdere onderzoeksresultaten van de Beer en Coon (2007). Ook zij vonden een $9 \%$ lagere voergift bij dagelijks voer verstrekken om hetzelfde gewicht aan het einde van de opfokperiode te bereiken. Zij concludeerden verder dat dagelijks voer verstrekken tijdens de opfokperiode vergelijkbare of verbeterde reproductie resultaten geeft ten opzichte van een skip-a-day voerprogramma. Daarnaast vonden Zuidhof et al. (2015) ook een verbeterde voerefficiëntie, maar ook vergelijkbare uniformiteit bij het toepassen van dagelijkse voeding t.o.v. verschillende voerprogramma's.

Het verschil in efficiëntie van voergebruik wordt veroorzaakt door de constante cyclus van voeren en vasten die tijdens de voerprogramma's met voerloze dagen plaatsvindt. Na de voeropname leggen de dieren de voedingsstoffen vast in het lichaam waarna die voedingsstoffen opnieuw gemobiliseerd worden om de lichamelijke biologische processen te faciliteren tijdens de voerloze dagen (de Beer en Coon, 2009). Deze afzetting en mobilisatie is geen perfect $100 \%$ efficiënt proces waardoor energie en andere nutriënten verloren gaan, en de dieren meer voer nodig hebben om hetzelfde lichaamsgewicht te bereiken. Daarnaast kan dagelijks voer verstrekken minder stress veroorzaken dan skip-a-day, wat blijkt uit lagere cortison- en insuline-achtige plasmaspiegels (Ekmay et al., 2010). Het dagelijks verstrekken van voer is goed management maar door aanpassingen (investering in moderne voersystemen) in de stal in combinatie met het integratie systeem (laag inkomen) wordt dit nog wereldwijd niet vaak geïmplementeerd.

Tijdens de opfokperiode van ouderdieren worden, meestal vanaf ongeveer 6 weken leeftijd verhoogde platforms of zitstokken aangeboden. Bij vleeskuikenouderdieren heeft een verhoogde rustplaats tijdens de opfokperiode de belangrijke functie om de dieren te trainen om de verticale ruimte van het systeem te benutten, waardoor minder grondeieren worden gelegd (Brake, 1987). Daarnaast is het natuurlijk een extra element in de stal die tegemoet komt aan de natuurlijke behoefte van kippen om 
op hoogte te rusten gedurende de nacht en te overnachten (Wood-Gush et al., 1978; Newberry et al., 2001; Schrader en Müller, 2010).

Hennen en hanen worden in separate stallen of afdelingen in dezelfde stal opgefokt, zodat zo verschillende voerschema's kunnen worden toegepast. Hanen en hennen hebben namelijk een ander geadviseerd gewichtsverloop, voerschema en voeropname gedrag. De fokkerijorganisatie adviseert in Nederland een bezettingsdichtheid voor de hennen van 8 tot 9 dieren per $\mathrm{m}^{2}$ en voor de hanen van 5 tot 6 dieren per $\mathrm{m}^{2}$ (Aviagen-EPI, 2017).

De meeste opfokstallen zijn volledig klimaat en licht gecontroleerd, zonder daglichttoetreding om de dieren bij een noodzakelijke daglengte van 8 uur te kunnen houden. In opfokstallen wordt meestal na circa 3 weken een lichtprogramma met 8 uur licht per dag toegepast met een lichtintensiteit tussen 10 en 20 lux (Aviagen-EPI, 2017; Cobb, 2016; Hubbard, 2017). In het geval van problemen met pikkerij of om de activiteit van de dieren te verminderen worden soms ook lagere lichtintensiteiten toegepast (EFSA, 2010). De managementgidsen van de fokkerijorganisaties worden meestal als basis genomen voor de bezettingsdichtheid, het lichtprogramma, het voerprogramma, etc. (Aviagen-EPI, 2017; Cobb, 2016; Hubbard, 2017). Figuur 7 toont een voorbeeld van een opfokstal in Nederland.

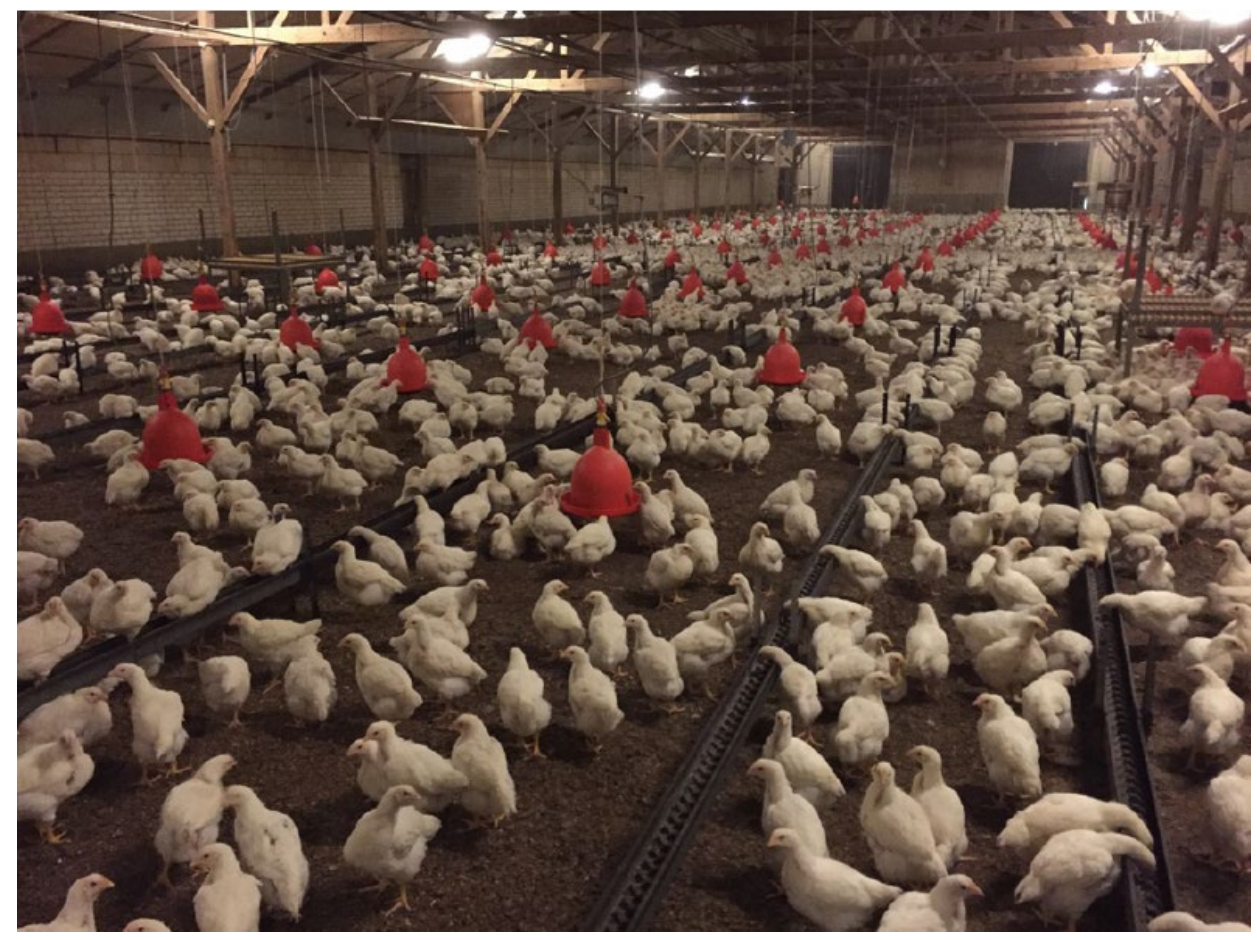

Figuur $7 \quad$ Voorbeeld opfokstal met sleepketting, ronddrinkers, springtafels, etc.

\subsection{Huisvesting en management legperiode}

Het belangrijkste doel bij de productie van vleeskuikenouderdieren is het produceren van bevruchte eieren voor een maximaal aantal gezonde en robuuste eendagskuikens (Zuidhof et al., 2007).

Belangrijk bij het houden van ouderdieren is het handhaven van de gezondheidsstatus van het koppel terwijl de eierproductie op een hoog niveau wordt gehouden. Belangrijke criteria voor het monitoren van het management bij ouderdieren zijn lichaamsgewicht, lichaamsconditie, eierproductie, $1^{\mathrm{e}}$ soort broedeieren, eigewicht, bevruchting, uitkomst en uitval (Leeson en Summers, 2000).

De overgang van de opfok- naar de productieperiode omvat het transport naar de legstallen op een apart legbedrijf (ook wel vermeerderingsbedrijf). De dieren worden overgeplaatst op gemiddeld 20 weken leeftijd, de productie begint op 23 weken leeftijd en duurt tot 60-62 weken leeftijd, afhankelijk van de prestaties van het koppel en de broedeimarkt situatie. De hennen en hanen die apart zijn opgefokt worden aan het begin van de productieperiode gemengd, en komen meestal op dezelfde dag aan op het vermeerderingsbedrijf (Aviagen-EPI, 2017; Cobb, 2016; Hubbard, 2017).

De meerderheid van de ouderdieren is tijdens de productieperiode gehuisvest in stallen met grondhuisvesting. De stallen hebben meestal kunstlicht (TL, HF-TL, LED). 
Grondstallen bestaan uit een strooiselgedeelte en een bepaald percentage (35 tot 70\%) verhoogde $(25$ tot $50 \mathrm{~cm}$ ) roostervloer (hout of kunststof) van waaruit de nesten toegankelijk zijn. Strooisel op de vloer bestaat meestal uit houtkrullen. Water wordt verstrekt via ronddrinkers, drinknippels of drinkcups op het rooster die op korte afstand van het legnest geplaatst zijn om het leggen van eieren in het legnest te bevorderen. Voer voor de hennen kan in verschillende vormen (meel, pellet of kruimel) worden verstrekt via sleepketting, voerpannen of Bridomat met een systeem (grill of rol) om de hanen uit te sluiten. Het voersysteem wordt meestal zowel op het strooisel als op het rooster geplaatst. De hanen worden meestal gevoerd via een sleepketting of voerpannen die tegen de wanden bevestigd zijn. Het hanen voersysteem hangt op minimaal $50 \mathrm{~cm}$ hoogte zodat de hennen er niet bij kunnen. De henen en hanen worden dus gescheiden gevoerd, omdat ze een verschillende hoeveelheid voer moeten krijgen i.v.m. de verschillen in gewichtsontwikkeling. Daarnaast kan er een speciaal hanenvoer (minder energie, ruw eiwit, aminozuren en calcium) verstrekt worden. Tijdens de productieperiode wordt voercontrole, om het lichaamsgewicht te beheersen, alleen tijdens de eerste 5 weken van de legperiode toegepast. Het niveau van de voercontrole is duidelijk lager in vergelijking met de opfokperiode (de Jong en Jones, 2006). Controle op de watergift wordt meestal ook toegepast, om overdrinken en vermorsing te voorkomen (EFSA, 2010). Figuur 8 toont een voorbeeld van een stal met vermeerderingsdieren in Nederland.

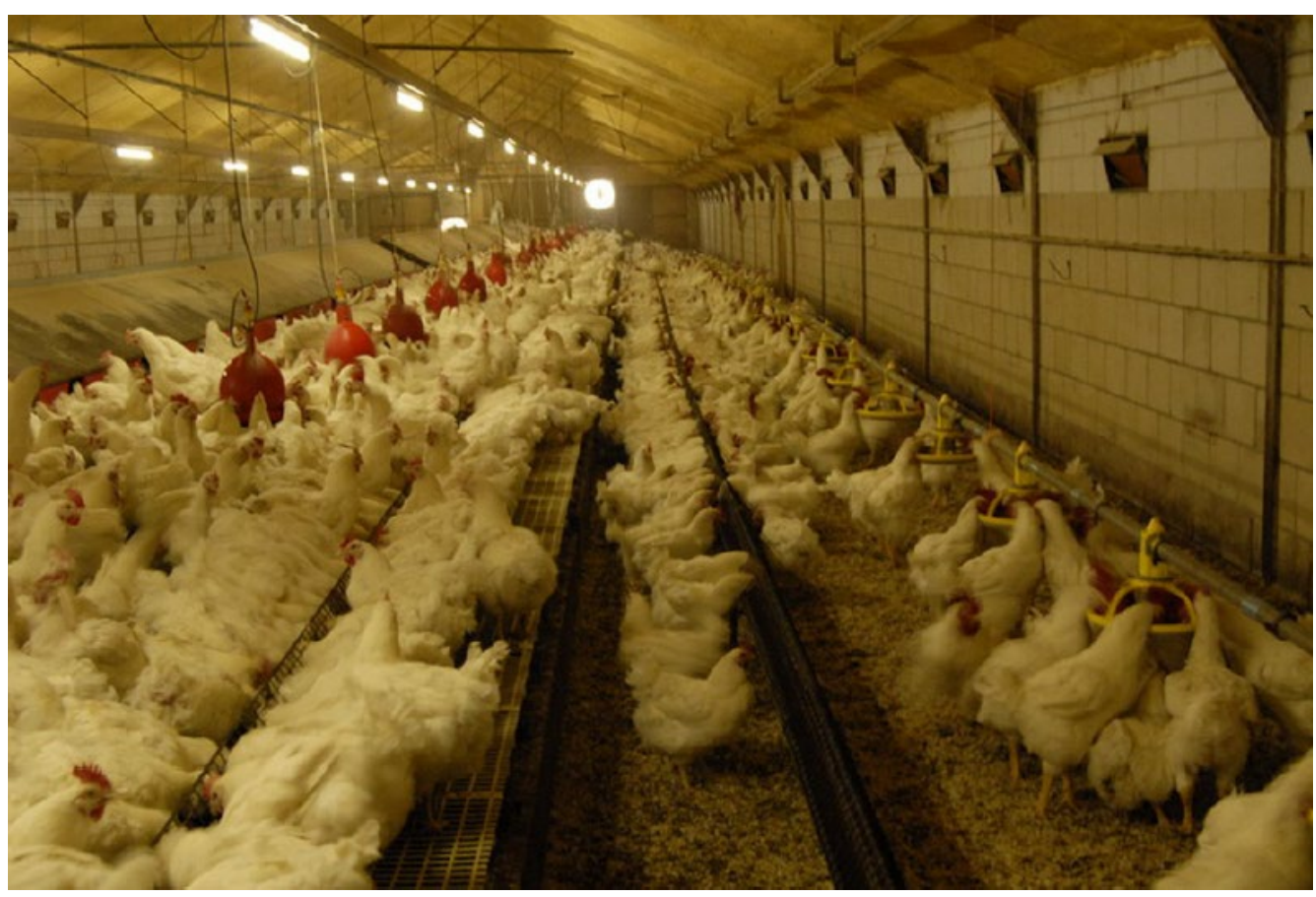

Figur 8 Voorbeeld legstal (of vermeerderingsstal) met sleepketting, ronddrinkers, rooster, TIverlichting, inlaatventielen en lengteventilatie.

De bezettingsdichtheid tijdens de productieperiode varieert in Nederland tussen de 7 en 7,7 dieren (hennen en hanen) $/ \mathrm{m}^{2}$. Het percentage hanen aan het begin van de productieperiode (20 weken leeftijd) ligt tussen 9 en $10 \%$, en dit neemt gedurende de productieperiode af door selectie en uitval van hanen. Bij aanvang van de productie rond de leeftijd van 23 weken zijn 8-9\% hanen aanwezig in een koppel (EFSA, 2010). Het selectiecriterium van hanen omvat het ontbreken van paringsactiviteit en gezondheidsproblemen (bijv. pootproblemen). Tijdens de productieperiode wordt ongeveer $25 \%$ van de hanen geselecteerd en uit de koppel gehaald. Bij ongeveer 60 tot $70 \%$ van de koppels worden vanaf 40 weken leeftijd nieuwe en gezonde hanen (gemiddeld 1,3\%) bijgeplaatst (van Emous, 2018). Inactieve hanen worden uit de koppel verwijderd en vervangen door jongere en actievere hanen om de bevruchting van de eieren op een hoog niveau te houden (Leeson en Summers, 2000). Bijplaatsen van hanen houdt echter het risico in van de introductie van ziekteverwekkers en het kan stressvol zijn voor de hennen (en soms ook hanen) omdat de agressie bij de hanen kan toenemen (EFSA, 2010). 


\subsection{Reproductie ouderdieren}

De core business van de ouderdierensector is het produceren van zoveel mogelijk bevruchte $1^{\mathrm{e}}$ soort broedeieren van minimaal 50 gram. Daarom zijn in ouderdierenstallen zowel hanen als hennen aanwezig. Dit is meteen ook de grootste uitdaging van de sector: het managen van twee totaal verschillende dieren met hun eigen specifieke eisen op het gebied van voeding, verzorging, huisvesting en management. Door de doorlopende genetische veranderingen t.a.v. van groei en efficiëntie van de vleeskuikens dient ook het (re)productiemanagement continue te worden aangepast. De selectie op productie parameters heeft ook een effect op de vleeskuikenouderdieren. In principe hebben ouderdieren vergelijkbare genetische eigenschappen als vleeskuikens (snelle groei en efficiënte productie van borstvlees), maar niet hetzelfde doel: ze moeten broedeieren produceren. Deze productieparameters zijn tegenstrijdig aan elkaar, waardoor aanpassingen nodig zijn aan het management en inrichting. Dit om de (re)productie en dus de efficiëntie en rendement van de keten en sector op niveau te houden of waar mogelijk te verbeteren (van Emous, 2018).

Uit gegevens van Aviagen-EPI blijkt dat de productiviteit van de ouderdieren tussen 2008 en 2018 sterk is toegenomen (Figuur 9). Het aantal broedeieren p.o.h. is met circa 13 stuks (van ca. 160 naar 173 stuks) toegenomen. Daarnaast is ook de uitkomst met circa 6\%-punt (van ca. 78,5 naar 84,5\%) gestegen. Dit resulteerde in een toename van het aantal kuikens p.o.h. met 20 kuikens (van 126 naar 146 stuks) in 10 jaar tijd! Daarnaast is de uitval van ouderdieren in die periode met 2\%-punt (van 11 naar $9 \%$ ) gedaald wat ook een positieve invloed heeft op de productie resultaten per opgehokte hen. De verbeterende (re)productie resultaten zijn met name te danken aan de genetische vooruitgang, maar zeker ook aan verbeteringen aan management en systeem in de stallen.

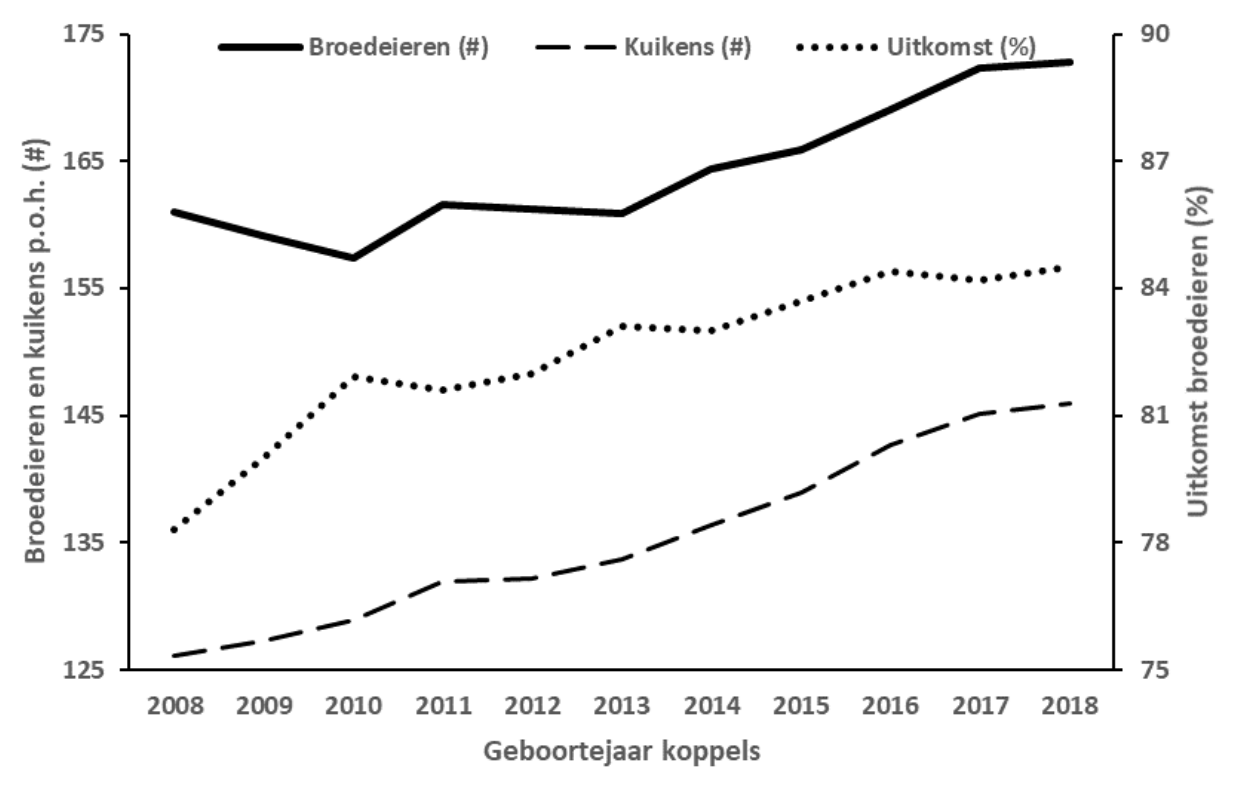

Figuur 9 Ontwikkeling van de uitval en geproduceerde kuikens per ouderdier geboren 2008-2018 (Bron: Aviagen-EPI).

Uit praktijkdata blijkt ook dat de hoeveelheid voer tijdens de legperiode gedurende het laatste decennium nagenoeg gelijk is gebleven (circa 45,5 kg p.o.h.). Hierdoor is de hoeveelheid voer per geproduceerd kuiken tussen 2008 en 2018 met 49 gram (van 361 naar 312 g) afgenomen. Tabel 5 laat de berekeningen en uitgangspunten zien van de besparing op landgebruik bij productie van kuikens. Voor de belangrijkste ingrediënten (mais, tarwe, zonnebloemschroot en sojaschroot) in het Nederlandse foktoomvoer is gerekend met een opbrengst van 6,7 ton per hectare (gewogen gemiddelde). Voor Europa en de gehele wereld is gerekend met een opbrengst van respectievelijk 5,6 en 4,7 ton per hectare. Verder is voor de berekeningen aangenomen dat het kuikenaantal hetzelfde was in 2008 en 2018, respectievelijk 250, 8.200 en 64.400 miljoen reguliere vleeskuikens per jaar in Nederland, Europa en de wereld. Ook is verondersteld dat het lichaamsgewicht hetzelfde is gebleven in 2008 en 2018, respectievelijk 2,4, 2,2 en 2,2 kg voor Nederland, Europa en de wereld.

In de berekeningen is de productie vergeleken van het totaal aantal reguliere vleeskuikens per jaar geproduceerd door ouderdieren in 2018 t.o.v. ouderdieren in 2008. 
Door het aantal vleeskuikens te vermenigvuldigen met de uitgespaarde voerhoeveelheid per geproduceerd kuiken ontstaat de totale besparing op foktoomvoer. De besparing op het voer is gedeeld door de opbrengst per hectare om de vermindering van het landgebruik te berekenen. Als voorbeeld voor Nederland: 250 miljoen kuikens maal 49 gram geeft 12.250 ton besparing op foktoomvoer. Gedeeld door de opbrengst per hectare (gemiddeld: 6,7) geeft dit een besparing van 1.830 hectare grond om in 2018 hetzelfde aantal kuikens te produceren als in 2010 (Tabel 5). Rekenend met de getallen voor Europa en de wereld is de besparing respectievelijk 401.800 en 3.155 .600 ton voer en 71.895 en 669.160 hectare per jaar (30\% van de landbouwgrond in Nederland). Al met een al een besparing op het wereldwijde voerverbruik en dus ook wereldwijde landgebruik van $13,6 \%$. Doordat er nog steeds een grote spreiding op reproductieresultaten is tussen de $25 \%$ slechtste en $25 \%$ beste koppels ouderdieren is de indruk dat dit nog verder verbeterd kan worden. Sowieso voorspellen de fokkerijorganisaties voor de komende jaren verdere genetische vooruitgang op het gebied van groei en voederconversie. Daarnaast zullen aanpassingen van management en huisvestingsystemen de reproductie resultaten op het individueel vermeerderingsbedrijf verder verbeteren.

Tabel $5 \quad$ Uitgangspunten en berekeningen voor de besparing op wereld landgebruik voor

\begin{tabular}{|c|c|c|c|c|c|c|}
\hline \multirow[b]{2}{*}{ Jaar } & \multicolumn{2}{|c|}{ NL } & \multicolumn{2}{|c|}{ EU-27 } & \multicolumn{2}{|c|}{ Wereld } \\
\hline & 2008 & 2018 & 2008 & 2018 & 2008 & 2018 \\
\hline \multicolumn{7}{|l|}{ Uitgangspunten } \\
\hline Opbrengst (ton/ha) $)^{1}$ & 8,1 & 8,1 & 6,2 & 6,2 & 5,5 & 5,5 \\
\hline Aantal vleeskuikens/jaar (miljoen) & 250 & 250 & 8.200 & 8.200 & 64.400 & 64.400 \\
\hline Eindgewicht kuikens (kg) & 2,4 & 2,4 & 2,2 & 2,2 & 2,2 & 2,2 \\
\hline \multicolumn{7}{|l|}{ Berekeningen } \\
\hline Totaal foktoomvoer (1000 ton/jaar) & 90 & 78 & 2.960 & 2.558 & 23.248 & 20.093 \\
\hline Wereld landgebruik (1000 ha/jaar) & 13,5 & 11,7 & 530 & 458 & 4.930 & 4.261 \\
\hline Besparing foktoomvoer (ton/jaar) & \multicolumn{2}{|c|}{12.250} & \multicolumn{2}{|c|}{401.800} & \multicolumn{2}{|c|}{3.155 .600} \\
\hline Besparing op landgebruik (ha/jaar) & \multicolumn{2}{|c|}{1.830} & \multicolumn{2}{|c|}{71.895} & \multicolumn{2}{|c|}{669.160} \\
\hline
\end{tabular}

${ }^{1}$ Gewogen gemiddelde van mais, tarwe, sojaschroot, zonnebloemschroot.

\subsection{Samenvatting vleeskuikenouderdieren}

Vleeskuikenouderdieren zijn het middelpunt van de pluimveevleesketen omdat ze broedeieren, en dus kuikens, produceren die na een groeiperiode op vleeskuikenbedrijven verwerkt worden tot verschillende soorten pluimveevlees.

Het huidige vleeskuiken is ontstaan na circa 70 jaar fokkerij en selectie van oorspronkelijke rassen. Het kuiken is in die tijd veranderd van een smal kuiken van minder dan 500 gram naar een breed vleeskuiken van circa 2,5 kg op 6 weken leeftijd. Daarbij is het aandeel borstfilet bijna verdubbeld en het vetgehalte gehalveerd. Dit heeft grote gevolgen voor de efficiëntie van pluimveevlees waarbij de voederconversie in 70 jaar tijd van rond de 3,0 (3 kg voer voor $1 \mathrm{~kg}$ vlees) gehalveerd is naar 1,5. Op zijn beurt heeft dit weer grote gevolgen voor het landgebruik omdat vleeskuikenvoer bestaat uit de grondstoffen mais, tarwe en soja. Men schat dat door de jaarlijkse genetische vooruitgang de voederconversie met $1 \%$ per jaar afneemt en daarmee ook het landgebruik per ton pluimveevlees. Dit is nodig om aan de stijgende vraag naar pluimveevlees en toename van het aantal mensen in de wereld op een duurzame manier te blijven voldoen.

Ouderdieren worden de eerste 20 weken van hun leven op specifieke opfokbedrijven gehouden, waarna ze overgeplaatst worden naar legbedrijven en tot circa 60 weken leeftijd worden gehouden. Voorheen, en in veel ander landen in de wereld, werden opfok ouderdieren niet dagelijks gevoerd. Door welzijnsregels en meer inzicht in de effecten van deze zogenoemde voerprogramma's worden de dieren in Nederland dagelijks gecontroleerd gevoerd.

Naast een efficiënter vleeskuiken zijn de productieresultaten van vleeskuikenouderdieren de laatste 10 tot 15 jaar ook flink verbeterd bij een gelijkblijvende voergift. Dit betekent dat het landgebruik in die periode ook met ongeveer $1 \%$ per jaar lager is geworden door een lagere voergift per geproduceerd eendagskuiken. 


\section{$3 \quad$ Niveau voercontrole}

\subsection{Reden voercontrole}

Zoals besproken in hoofdstuk 2, is voercontrole bij ouderdieren nodig om de hoge groeisnelheid waar deze dieren genetisch voor zijn geselecteerd te verminderen (Johansson, 2016). Wanneer vrouwelijke vleeskuikens met vrouwelijke ouderdieren op dag 39 worden vergeleken, wegen vleeskuikens 2,2 kg en vrouwelijke ouderdieren 615 gram (Arrazola, 2018). Mannelijke vleeskuikens wegen op dag 35 2,2 $\mathrm{kg}$ en mannelijke ouderdieren 900 gram (Cooper en Wrathall, 2010). De voercontrole houdt de vruchtbaarheid optimaal en voorkomt groei gerelateerde gezondheidsproblemen zoals overgewicht, kreupelheid en mortaliteit (Heck et al., 2004; Dawkins en Layton, 2012; Johansson, 2016). Uit onderzoek van Heck et al. (2004) blijkt dat wanneer opfok ouderdieren onbeperkt gevoerd worden, dit resulteert in een 2,5 keer hoger gewicht $(5,4$ vs. $2,2 \mathrm{~kg})$ op 24 weken leeftijd. Dit geeft dan vervolgens een slechtere productie ( 79,1 vs. $52,4 \%$ leg) en zesmaal hogere uitval $(31,1$ vs. $6,1 \%)$ tot 40 weken leeftijd. Omdat ouderdieren langer worden aangehouden (tot ongeveer 60 weken) hebben problemen zoals overgewicht, slechte bevruchting, kreupelheid en mortaliteit een grote impact op het dierenwelzijn en op de economische opbrengst (Decuypere et al., 2010). Enerzijds is voercontrole dus nodig om het dierenwelzijn van de ouderdieren te bevorderen op basis van gezondheidsredenen. Anderzijds creëert voercontrole tegelijkertijd een nieuw dierenwelzijnsprobleem (D'Eath et al., 2009). Er zijn namelijk, indirecte aanwijzingen dat de ouderdieren honger ervaren (Mench, 2002). In de literatuur zijn er aanwijzingen dat voercontrole bij vleeskuikenouderdieren kan resulteren in afwijkende gedragingen dat indicatief kan zijn voor honger en frustratie. Dit uit zich in stereotiep pikgedrag naar objecten zoals muren, voer- en watersystemen, gaas, etc. en een te hoge wateropname (o.a. Hocking et al., 1996, 2001; Savory en Kostal, 1996; De Jong et al., 2002). Wetenschappers gaan ervan uit dat stereotiep pikgedrag ontstaat door de stress die dieren ondervinden vanwege frustratie door de controle van de voeropname. Dit probleem staat ook wel bekend als de 'broiler breeder paradox' (Decuypere et al., 2006; Decuypere et al., 2010). Dus ad libitum voer verstrekken heeft negatieve gevolgen voor gezondheid, welzijn en productie, maar aan de ander kant heeft de voercontrole negatieve effecten op gedrag en welzijn. EFSA (2009) vermeldt dat er echter nog onvoldoende onderzoek is gedaan in dit vakgebied om te kunnen zeggen of voercontrole invloed heeft op het welzijn van vleeskuikenouderdieren.

In een review studie uitgevoerd door Renema et al. (2007) werd geconcludeerd dat er een toenemende trend is waar te nemen in de mate van voercontrole in ouderdieren. De auteurs baseerden zich op de streefgewichten van vleeskuikens en vleeskuikenouderdieren op 6 weken leeftijd die afkomstig zijn van de fokkerijorganisatie gedurende de laatste 30 jaar. In Figuur 10 is deze data geüpdatet met informatie van de fokkerijorganisaties tot heden. Uit de figuur blijkt dat het verschil tussen het streefgewicht op 6 weken leeftijd tussen vleeskuikens en vleeskuikenouderdieren in de laatste 40 jaar sterk is toegenomen (van factor 1,9 naar 3,6). Volgens de normen van de fokkerijorganisaties is het streefgewicht van ouderdieren op 6 weken leeftijd nagenoeg gelijk gebleven terwijl het streefgewicht van de vleeskuikens op 6 weken leeftijd lineair is toegenomen. Om dit verschil in gewicht te ondervangen is de mate van voercontrole voor ouderdieren in de afgelopen 40 jaar dus ook flink groter geworden. 


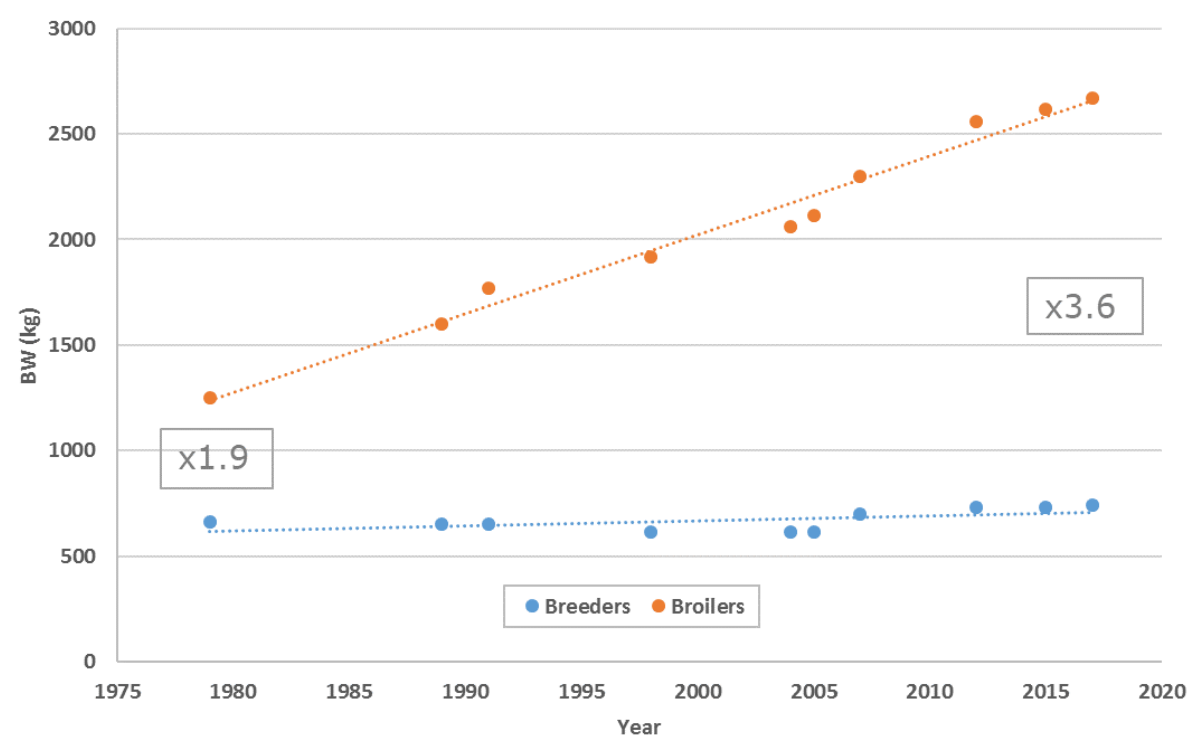

Figuur 10 Het streef lichaamsgewicht van vleeskuikens en vleeskuikenouderdieren op 6 weken leeftijd (aangepast naar Renema et al., 2007).

De oorzaak van voercontrole bij vleeskuikenouderdieren komt dus door het verschil tussen de streefgewichten van vleeskuikens en vleeskuikenouderdieren op dezelfde leeftijd. Ouderdieren hebben een vergelijkbaar groeipotentieel als hun nakomelingen (vleeskuikens) waardoor ze minder voer verstrekt krijgen dan dat ze zouden kunnen opnemen.

\subsection{Voercontrole naar leeftijd of gewicht?}

Tijdens de opfokperiode krijgen de jonge ouderdieren gedurende de eerste 2 weken ad libitum voer verstrekt waarna de voercontrole begint. In de literatuur wordt gesteld dat bij commercieel toegepaste voerprogramma's de voergift gecontroleerd wordt tot ongeveer 25 tot 33\% van de opname van ad libitum gevoerde dieren tijdens de opfokperiode (Savory et al., 1993; Savory en Kostal, 1996; de Jong et al., 2002). Dit betekent dus een voercontrole van 67 tot 75\%. Daarbij wordt aangegeven dat de periode met de sterkste voercontrole tussen 7-8 en 15-16 weken leeftijd ligt (Savory et al., 1993; de Jong en Jones, 2006). Tijdens de legperiode ligt het niveau van de voeropname tussen 45 tot $80 \%$ van de ad libitum voeropname van hennen op dezelfde leeftijd (Bruggeman et al., 1999). Dit betekent dus een voercontrole tussen 20 en 55\%. Echter, het bepalen van de mate van voercontrole bij vleeskuikenouderdieren op dezelfde leeftijd is geen goede vergelijking omdat er (grote) verschillen zijn in lichaamsgewicht bij gecontroleerd en ad libitum gevoerde opfokdieren (Savory et al., 1993). De voerbehoefte is voor een groot deel afhankelijk van het lichaamsgewicht door de behoefte aan energie voor onderhoud, en daarom heeft een zwaarder dier een hogere onderhoudsbehoefte voor energie. Savory et al. (1993) vergeleken de voeropname van opfokdieren op dezelfde leeftijd en kwamen op een voergift ten opzichte van ad libitum gevoerde dieren op 2 weken van $44 \%$ en tussen 7 en 15 weken leeftijd op een voergift van $25 \%$. Zoals hiervoor opgemerkt was het lichaamsgewicht in dat onderzoek bij de verschillende leeftijden echter verschillend. Daarom vergeleken zij de voeropname ook bij hetzelfde lichaamsgewicht. Op die manier kwamen zij op een voergift van 40 tot $48 \%$ (gemiddeld $45 \%$ ) ten opzichte van de ad libitum gevoerde dieren wat duidelijk hoger is dan de eerder genoemde 25 tot 33\%. Dus in plaats van een 67 tot $75 \%$ lagere voergift (bij dezelfde leeftijd) berekenden zij een $55 \%$ lagere voergift (voercontrole) bij hetzelfde lichaamsgewicht. 
Recent heeft Arrazola (2018) in zijn proefschrift een schatting gemaakt van het niveau van voercontrole bij ouderdieren op een vernieuwde manier. Om de voercontrole te schatten vergeleek hij de voeropname van een moderner ouderdier met de voeropname van vleeskuikens bij hetzelfde lichaamsgewicht. Hij verdeelde de opfokperiode in drie perioden: de vroege (tot 7 weken leeftijd), midden (vanaf 7 tot 15 weken leeftijd) en late opfok (van 15 circa 22 weken leeftijd) (Figuur 11 links). Uit de grafieken blijkt dat de voercontrole vooral tijdens de opfokperiode plaatsvindt en minder is tijdens de legperiode (Figuur 11 rechts). In de vroege opfokperiode (0-7 wk) ligt de voercontrole tussen de $0 \%$ (start opfok) en $50 \%$ (7 weken leeftijd), in de midden opfokperiode schommelt de voercontrole tussen 50 en $55 \%$ terwijl de voercontrole in de late opfokperiode afneemt van 55 naar $35 \%$. Volgens deze onderzoeker ligt de voercontrole tijdens de legperiode tussen de 35\% (begin leg) met de laagste voercontrole (ca. $20 \%$ ) rond de 30 weken leeftijd. In de tijd neemt de voercontrole weer wat toe tot $30 \%$ rond de 65 weken leeftijd.
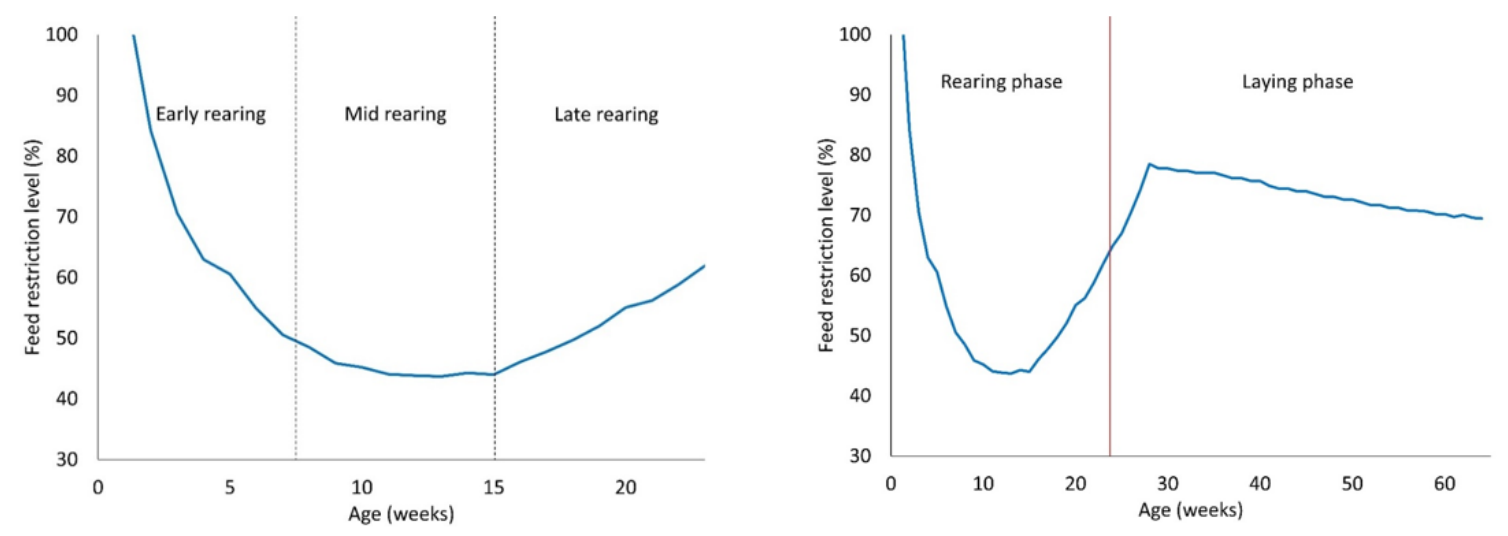

Figuur 11 Niveau van voercontrole bij Ross 308 vleeskuikenouderdieren gedurende de opfokperiode (links) en de gehele productieperiode (rechts) (Arrazola, 2018).

De voercontrole berekenen aan de hand van het lichaamsgewicht i.p.v. de leeftijd is een duidelijke verbetering naar een meer reëlere weergaven van het niveau van de voercontrole. Dit omdat zwaardere dieren meer voer nodig hebben voor onderhoud. Echter, voercontrole gaat niet zozeer om de hoeveelheid voer die dagelijks verstrekt wordt, maar om de nutriënten die dagelijks verstrekt worden. Een opfokouderdier zal minder groeien van een voeder met een lager gehalte aan energie en/of eiwit dan een voeder met hogere gehalten. Bij een voeder met lage nutriënt gehalten moet een hogere voergift worden verstrekt om hetzelfde streefgewicht aan het einde van de opfokperiode te bereiken (o.a. Enting et al., 2007, van Emous et al., 2013, 2015b). Voeders voor vleeskuikens hebben een hoger energiehalte dan voeders voor vleeskuikenouderdieren. Daarom zijn voor dit rapport nieuwe berekeningen uitgevoerd om de voergift te bepalen, met de meest recente normgewichten voor vleeskuiken hennen (Aviagen, 2019a) en vleeskuikenouderdieren (Aviagen, 2016a). Hierbij is gerekend met de verschillende energiegehaltes in het voer voor vleeskuikens (Aviagen, 2019b) en vleeskuikenouderdieren (Aviagen, 2016b) (Tabel 6).

Tabel $6 \quad$ Voeders voor de verschillende levensfases met bijbehorende energiegehaltes.

\begin{tabular}{cccc} 
Vleeskuikens (leeftijd) & $\begin{array}{c}\text { Energiegehalte } \\
(\mathrm{kcal} / \mathrm{kg})^{1}\end{array}$ & $\begin{array}{c}\text { Vleeskuiken- } \\
\text { ouderdieren (leeftijd) }\end{array}$ & $\begin{array}{c}\text { Energiegehalte } \\
(\mathrm{kcal} / \mathrm{kg})^{2}\end{array}$ \\
\hline $0-10 \mathrm{dg}$ & 3.000 & $6-5 \mathrm{wk}$ & 2.800 \\
\hline $11-20 \mathrm{dg}$ & 3.100 & $16-21 \mathrm{wk}$ & 2.600 \\
\hline $21-30 \mathrm{dg}$ & 3.150 & $>21 \mathrm{wk}$ & 2.700 \\
\hline$>30 \mathrm{dg}$ & 3.200 & & 2.800 \\
\hline
\end{tabular}

\footnotetext{
${ }^{1}$ Aviagen. 2019b.
}

${ }^{2}$ Aviagen, 2016b.

De resultaten van de berekeningen op energiecontrole op basis van vergelijkbaar lichaamsgewicht zijn in figuur 12 weergegeven. Daarbij is dus niet alleen gekeken naar de geadviseerde voergift (ouderdieren) of norm voeropname (vleeskuiken hennetjes) maar is ook de energieopname meegenomen. Daarnaast is een vergelijking gemaakt van de energieopname bij hetzelfde lichaamsgewicht (en dus verschillende leeftijden) van de ouderdieren en vleeskuikens. 
Door de energieopname mee te nemen in de berekeningen ligt de hoogste energiecontrole (58\%) tussen de 9 en 11 weken leeftijd. De energiecontrole tussen 7 en 16 weken leeftijd is gemiddeld $56 \%$. Uit de berekeningen blijkt dat de gemiddelde voercontrole tijdens de opfok- en legperiode respectievelijk 39 en $25 \%$ is. De energiecontrole tijdens de opfok- en legperiode is door het verschil in energieniveau van de vleeskuiken- en vleeskuikenouderdierenvoeders wat hoger, namelijk respectievelijk 47 en 35\%. Bij de bovenstaande berekening moet nog een kanttekening worden gemaakt omdat vleeskuikens niet helemaal gelijk zijn aan vleeskuikenouderdieren. Dit heeft te maken met het heterosis effect waarbij de nakomelingen het gemiddelde van beide ouders overtreft. Dit betekent dat in de hier gepresenteerde berekeningen mogelijk een overschatting gemaakt wordt waardoor de energiecontrole in werkelijkheid wat lager zal zijn. Er zijn geen gegevens uit de literatuur beschikbaar, en daarom is voor de berekeningen een schatting gedaan van $10 \%$. Dit betekent dat werkelijke energiecontrole circa $10 \%$ lager zal zijn: respectievelijk $42 \%$ en $31 \%$ voor de opfok- en legperiode. Dit is beduidend lager dan de 66 tot $75 \%$ en 20 tot $55 \%$ die in de literatuur wordt gehanteerd voor de opfok- en legperiode.

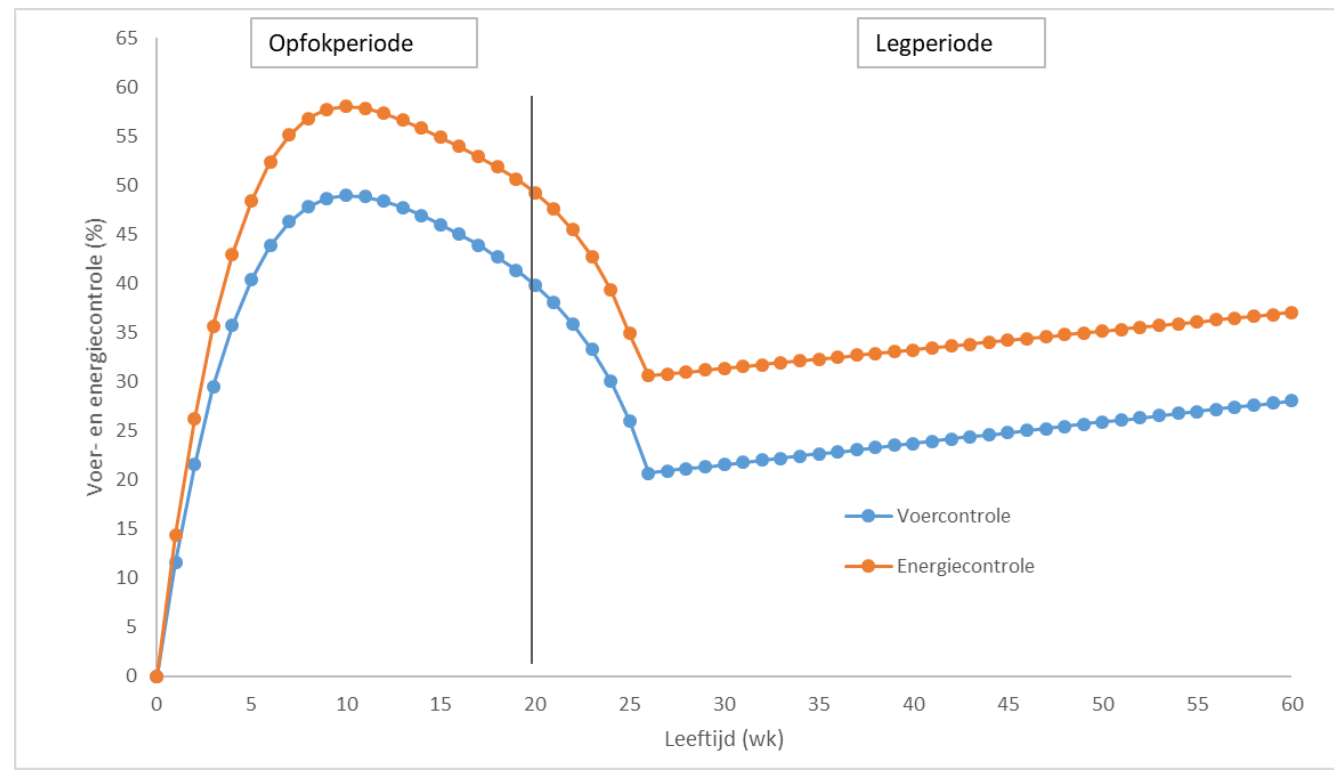

Figuur 12 Ontwikkeling berekende voer- en energiecontrole Ross 308 vleeskuikenouderdieren gedurende de opfok- en productieperiode.

\subsection{Factoriele berekening voercontrole}

De behoefte aan energie (en dus voergift) kan ook via een factoriele benadering worden bepaald met behulp van het gewicht (onderhoudsbehoefte) en groei voor de opfokperiode en gewicht, groei en productie voor de legperiode (Sakomura et al., 2003). Hierbij moet rekening worden gehouden met een afnemende bevedering van de dieren tijdens de legperiode (de Jong en van Emous, 2017). Tevens wordt in de modellen rekening gehouden met de omgevingstemperatuur omdat die belangrijk is voor de onderhoudsbehoefte. Voor de opfokperiode worden in dit rapport de twee modellen gebruikt die door Sakomura et al. (2003) ontwikkeld zijn voor de verschillende levensfasen van het dier (Tabel 7). Zij hebben de modellen getest en vonden dat de gewichten goed overeen kwamen met de normen zoals aangegeven door de fokkerijorganisatie. Verder gaven ze aan dat het tweede model het meest nauwkeurig de energiebehoefte van opfok ouderdieren benaderde. 
Tabel 7 Modellen voor de berekening energiebehoefte tijdens de opfok (Sakomura et al., 2003).

\begin{tabular}{|c|c|}
\hline Leeftijd (wk) & Formule $^{1}$ \\
\hline \multicolumn{2}{|l|}{ Model 1} \\
\hline $1-8$ & $W^{0.75}(186.52-1.94 T)+2.47 W G$ \\
\hline $9-14$ & $W^{0.75}(186.52-1.94 T)+2.69 W G$ \\
\hline $15-20$ & $W^{0.75}(186.52-1.94 T)+2.76 W G$ \\
\hline \multicolumn{2}{|l|}{ Model 2} \\
\hline $1-8$ & $W^{0.75}(174.15-1.88 T)+2.83 W G$ \\
\hline $9-14$ & $W^{0.75}(174.15-1.88 T)+2.50 W G$ \\
\hline $15-20$ & $W^{0.75}(174.15-1.88 T)+3.24 W G$ \\
\hline
\end{tabular}

${ }^{1} \mathrm{~W}=$ gewicht $(\mathrm{kg}), \mathrm{T}=$ temperatuur en $\mathrm{WG}=$ dagelijks groei $(\mathrm{g})$

Bovenstaande formules zijn gebruikt om de theoretische energiebehoefte (en voergift) van opfok ouderdieren te berekenen en te vergelijken met de geadviseerde voergift van de fokkerijorganisatie (Aviagen, 2016a). Om de energieopname te berekenen werden de geadviseerde normen voor voergift en energiegehalten van de verschillende voeders van de fokkerijorganisatie gebruikt.

In figuur 13 zijn de geadviseerde energieopname (Aviagen, 2016a,b) en de 2 modellen voor energiebehoefte weergegeven. Uit de figuur blijkt dat de berekende behoefte uit beide modellen vanaf 3 weken leeftijd boven de geadviseerde energieopname ligt. De geadviseerde dagelijkse energiegift was tot 5 weken ongeveer gelijk aan de berekeningen om daarna af te wijken tot aan het einde van de opfokperiode. Het verschil aan het einde van de opfokperiode werd weer kleiner. In de periode tussen 6 en 15 weken leeftijd is de aanbevolen energieopname gemiddeld $19 \%$ lager dan de berekende energiebehoefte. Gemiddeld over de gehele opfokperiode was de energieopname gemiddeld $12 \%$ lager dan de berekende energiebehoefte vanuit de 2 modellen.

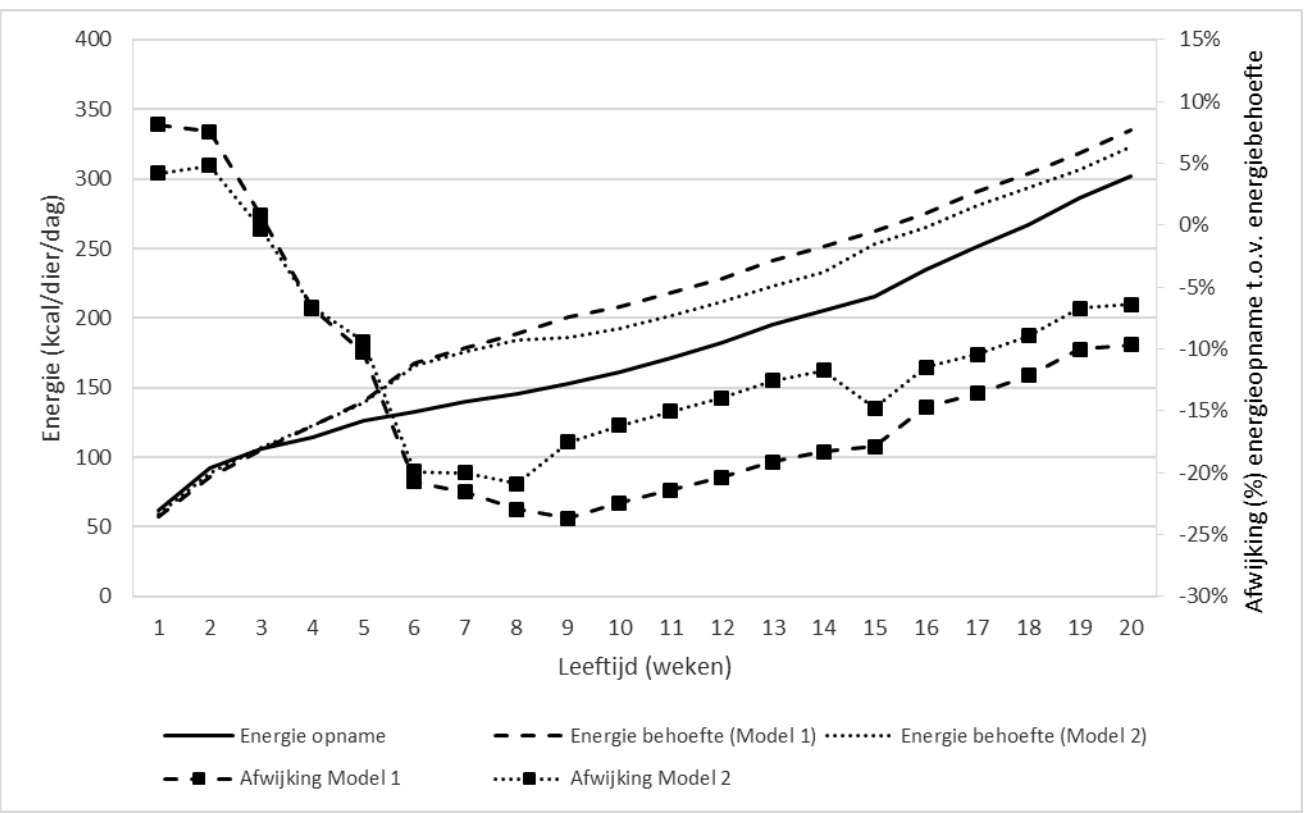

Figuur 13 Ontwikkeling energieopname (Aviagen, 2016a,b) en energiebehoefte volgens 2 modellen (Sakomura et al., 2003) en afwijking (\%) van de energieopname t.o.v. de energiebehoefte.

Er zijn ook berekeningen uitgevoerd voor de legperiode gebaseerd op de wetenschappelijke publicatie van Rabello et al. (2006) (Tabel 8). De energiebehoefte tijdens de legperiode bestaat uit een optelsom van energie benodigd voor onderhoud (met correctie voor temperatuur), eiproductie en groei. Daarnaast is rekening gehouden met een toenemende behoefte aan energie voor onderhoud door de afnemende bevedering. Deze is bepaald door een combinatie van de bevederingsscore in relatie tot een hogere energiebehoefte bij een bepaalde score (Aviagen-EPI, 2017). 


\begin{tabular}{|c|c|}
\hline Onderdeel & Formule $^{1}$ \\
\hline Onderhoud & $\mathrm{kg} \mathrm{W}^{0,75 *\left(806,53-26,45 * T+0,50 * \mathrm{~T}^{2}\right)}$ \\
\hline Eiproductie & $10,04 * \mathrm{EM}$ \\
\hline Groei & $31,90 * G$ \\
\hline Bevedering $^{2}$ & $11,20 * \mathrm{~B}$ \\
\hline
\end{tabular}

Deze formule is gebruikt voor berekeningen met Ross 308 data (Aviagen, 2016a) en de resultaten daarvan zijn weergegeven in Figuur 14. Het blijkt dat de aanbevolen energieopname in het begin van de legperiode wat achterblijft op de energiebehoefte maar vanaf 29 weken leeftijd is de energieopname ongeveer op het niveau van de berekende energiebehoefte. Vanaf die leeftijd tot aan het einde van de legperiode schommelt de energieopname rond de energiebehoefte. Dit is ook nodig om te voorkomen dat de dieren in een negatieve energiebalans komen, spontaan gaan ruien en stoppen met het produceren van broedeieren (van Emous, 2015). Tot 30 weken leeftijd verkeren de dieren in een lichte negatieve energiebalans en is de energieopname gemiddeld $10 \%$ lager dan de berekende energiebehoefte. Gemiddeld over de gehele legperiode is de energieopname $4 \%$ lager dan de energiebehoefte.

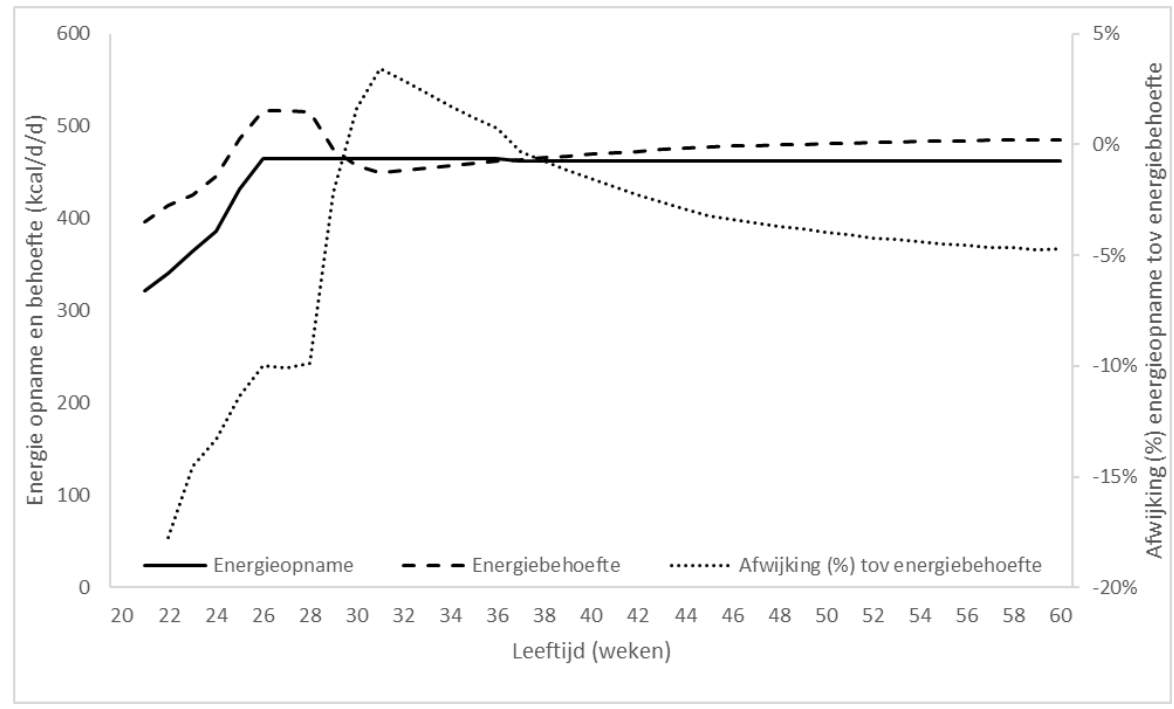

Figuur 14 Ontwikkeling energieopname (Aviagen, 2016a) en energiebehoefte gedurende de legperiode volgens het model van Rabello et al. (2006) en afwijking energieopname (\%) t.o.v. de energiebehoefte.

In tegenstelling tot leghennen hebben ouderdieren een groot gedeelte van de dagelijkse energieopname nodig voor het onderhoud van het relatief zware lichaam (Figuur 15). Dit komt doordat de ouderdieren in het begin van de legperiode snel groeien naar een gemiddeld gewicht van 3.500 gram op 30 weken leeftijd wat veroorzaakt wordt door de snelle verhoging van de voergift. De ouderdieren groeien tussen 20 en 25 weken leeftijd namelijk gemiddeld 150 gram per week en tussen 26 en 30 weken leeftijd meer dan 80 gram per week. Vanaf 30 weken leeftijd groeien de ouderdieren nog maar gemiddeld 20 gram per week. Gemiddeld over de gehele legperiode is circa $70 \%$ (65\% onderhoud en 5\% afname bevedering) nodig om de lichaamsprocessen in stand te houden. Vanaf 25 weken leeftijd stijgt de broedeiproductie snel waardoor het aandeel energie voor productie toeneemt naar iets meer dan 25\% van de dagelijkse behoefte (zie ook Figuur 15).

Leghennen daarentegen wegen veel minder (van ca. 1,4 kg start naar 1,8 kg einde leg) waardoor deze dieren relatief veel minder energie nodig hebben voor onderhoud, een heel klein beetje voor groei. Leghennen gebruiken circa $50 \%$ van de energie voor onderhoud (en groei) en circa $50 \%$ voor productie. 


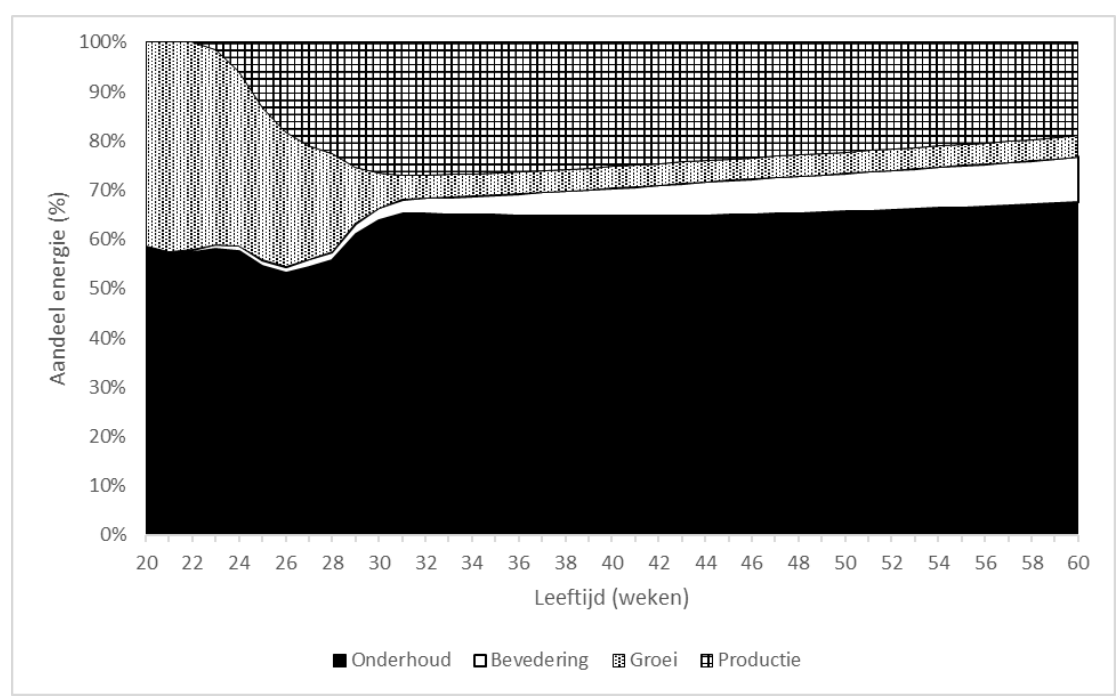

Figuur 15 Ontwikkeling verdeling energiebehoefte naar verschillende gedurende de legperiode (van Emous, niet gepubliceerde data).

Naast energie heeft een opfok ouderdier ook behoefte aan eiwit (aminozuren) om spierweefsel aan te maken en voor onderhoud. Gemiddeld over de gehele opfokperiode wordt circa $74 \%$ van het eiwit gebruikt voor aanmaak spieren en $26 \%$ voor onderhoud (da Silva-Filardi et al., 2004). Berekeningen naar de eiwitbehoeften per levensfase van opfok ouderdieren zijn uitgevoerd met formules van da Silva-Filardi et al. (2004) (Tabel 9). Daarnaast werden de geadviseerde normen van de fokkerijorganisatie (Aviagen, 2016a,b) voor voergift en eiwitgehalte van de verschillende voeders gebruikt om de eiwitopname te berekenen.

Tabel 9 Model voor de berekening van de eiwitbehoefte tijdens de opfok (da Silva-Filardi et al., 2004).

\begin{tabular}{ll} 
Leeftijd (wk) & Formule \\
$0-8$ & $2,02 * W^{0.75}+0,350 * G$ \\
\hline $9-14$ & $2,02 * W^{0.75}+0,406 * G$ \\
\hline $15-20$ & $2,02 * W^{0.75}+0,463 * G$ \\
\hline
\end{tabular}

${ }^{1} \mathrm{~W}=$ gewicht $(\mathrm{kg})$ en $\mathrm{G}=$ dagelijks groei $(\mathrm{g})$

Uit figuur 16 blijkt dat de eiwitopname tijdens de eerste vijf weken rond de eiwitbehoefte ligt. Tussen 6 en 9 weken ligt de eiwitopname gemiddeld $11 \%$ onder de eiwitbehoefte. Vanaf 10 weken leeftijd ligt de eiwitopname gemiddeld $15 \%$ boven de eiwitbehoefte en neemt toe in de tijd. Gemiddeld over de gehele opfokperiode ligt de eiwitopname $5 \%$ hoger dan de eiwitbehoefte. 


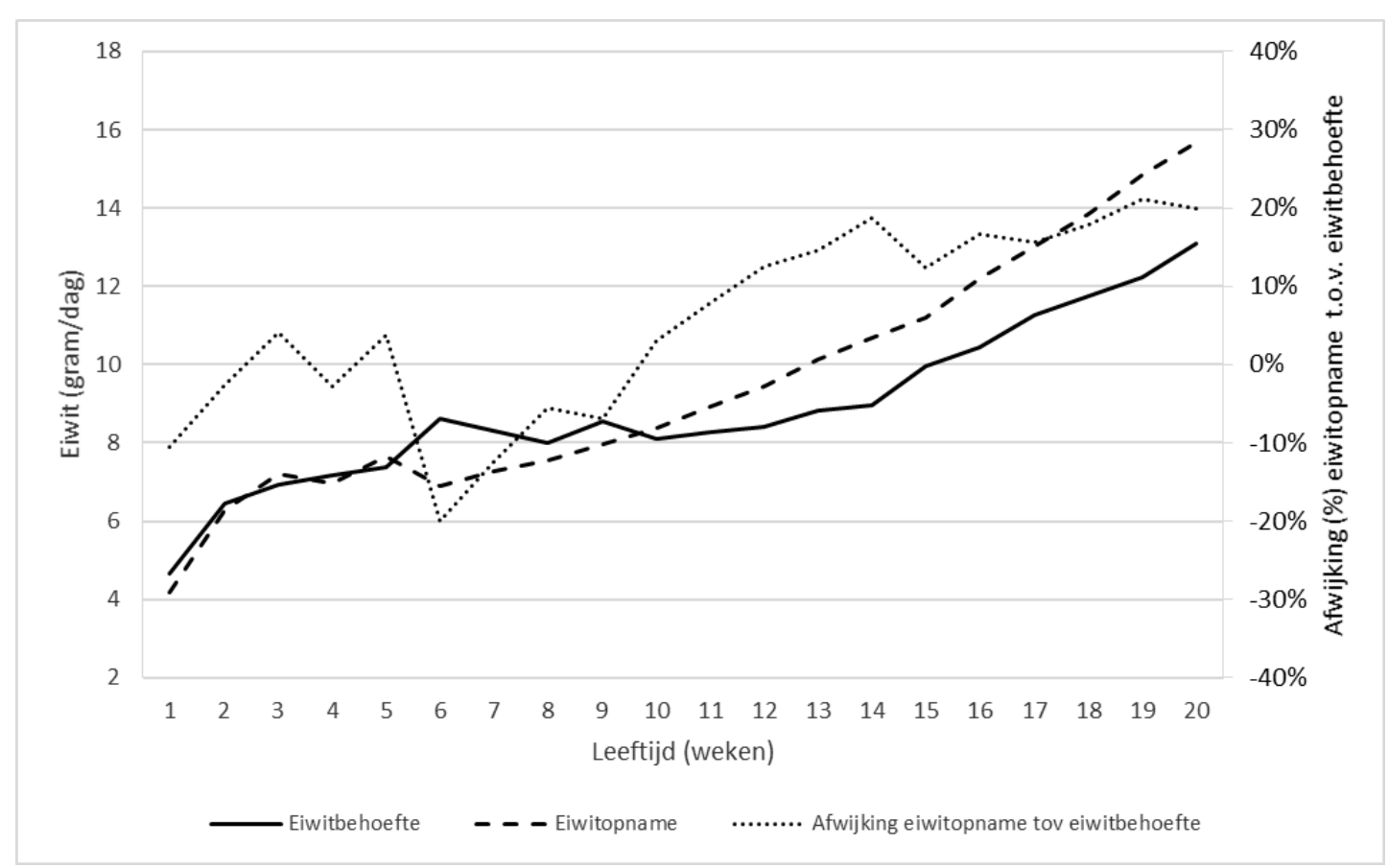

Figuur 16 Ontwikkeling eiwitopname (Aviagen, 2016a,b) en eiwitbehoefte volgens het model van da Silva-Filardi et al. (2004) en de afwijking (\%) van de eiwitopname t.o.v. de eiwitbehoefte.

\subsection{Samenvatting niveau voercontrole}

Voercontrole bij vleeskuikenouderdieren is het middel om het verschil tussen de streefgewichten op dezelfde leeftijd van vleeskuikens en vleeskuikenouderdieren te bewerkstelligen. Ouderdieren hebben min of meer vergelijkbaar groeipotentieel als hun nakomelingen (vleeskuikens) waardoor ze minder voer verstrekt krijgen dan dat ze zouden kunnen opnemen.

Voorheen ging men uit van een voercontrole van 67 tot $75 \%$ maar dit was gebaseerd op de voeropname op een dezelfde leeftijd (en dus verschillend gewicht) en niet op een vergelijking op hetzelfde lichaamsgewicht. Daarom is in dit rapport uitgegaan van de theoretische voergift/voeropname bij een vergelijkbaar lichaamsgewicht. Verder is gekeken naar de energieopname wat de werkelijke controle nog dichter benadert. Uit deze berekeningen blijkt dat de energiecontrole tijdens de opfok- en legperiode respectievelijk $47 \%$ en $35 \%$ is. Doordat ouderdieren niet exact hetzelfde groeipotentieel hebben, en door het heterosis effect bij de nakomelingen, is dit mogelijk een overschatting en zal de werkelijke voercontrole wat lager zijn. De inschatting is dat de werkelijke energiecontrole circa $10 \%$ lager zal zijn: respectievelijk $42 \%$ en $31 \%$ voor de opfok- en legperiode. Dit is beduidend lager dan de 66 tot $75 \%$ en 20 tot 55\% die in de literatuur wordt gehanteerd voor de opfok-en legperiode.

Daarnaast zijn factoriële berekeningen uitgevoerd om de energie- en eiwitbehoefte te berekenen. Uit de berekeningen blijkt dat de dieren tijdens de opfok- en legperiode respectievelijk een $12 \%$ en $3 \%$ lagere energiegift kregen t.o.v. de energiebehoefte. Gemiddeld over de gehele opfokperiode ligt de eiwitopname $5 \%$ boven de eiwitbehoefte. 


\section{Effecten voercontrole}

Een overzicht van experimenten uitgevoerd bij gecontroleerd gevoerde ouderdieren met de effecten op fysiologie, gedrag en productie is weergegeven in bijlage 1 tot en met 3 .

\subsection{Effecten op fysiologie}

Voercontrole en frustratie van de motivatie om voer op te willen nemen, kunnen negatieve effecten geven op de homeostase (= proces van dier om het interne milieu van chemische en fysische processen in evenwicht te houden). Dit is een gevolg van onbevredigende interne prikkels die de emotionele toestand van het dier aansturen (Primrose et al., 2007). Als een dier niet voldoende voedsel opneemt, kan dit stressvol zijn en aanhoudende stress kan leiden tot gezondheidsproblemen. Dit heeft dan niet alleen schadelijke effecten op de fysieke en mentale homeostase van het dier, maar heeft ook een negatieve invloed op het vermogen van het dier om moeilijke situaties het hoofd te bieden (veerkracht) (Keeling et al., 2011). Om deze reden wordt in studies naar dierenwelzijn vaak de stressrespons gebruikt als (indirecte) indicator van de mentale gesteldheid van het dier (Arrozola, 2018).

Het optreden van een dreigende stimulans of het niet handhaven van de interne homeostase activeert de stressreactie (Blas, 2015). De perceptie van de stressor activeert een specifieke gedrags- en fysiologische stressreactie (Veissier en Boissy, 2007), gefaciliteerd door de hypothalamus-hypofysebijnier (HPA)-as (Scanes, 2016). Activering van een stressreactie kan onder andere gemeten worden aan de corticosteron concentratie in het bloedplasma. Het optreden van negatieve ervaringen kan de afgifte van corticosteron in de bloedsomloop stimuleren (Mormède et al., 2007). Corticosteron wordt afgegeven door de bijnieren, als respons op activering van de HPA-as. De afgifte van corticosteron kan minuten tot uren duren en de verhoogde corticosteron concentratie kan enige tijd aanhouden nadat de stressvolle prikkel verdwenen is (Blas, 2015). Corticosteron wordt daarom beschouwd als een welzijnsindicator voor acute stressreacties op de korte termijn. Echter, bij chronische stress kan een acute respons gevoeliger reageren en daarom kan de respons op een acute stressor een indicator zijn voor een meer chronische stress situatie. Chronisch verhoogde concentraties van plasma corticosteron verwijzen naar langdurig verminderd welzijn (de Jong et al., 2003; Lynn et al., 2010). Aangezien corticosteron een glucocorticoïd hormoon is dat betrokken is bij zowel de regulering van glucose concentratie in het bloed als bij de stressreactie (Scanes, 2016), staat het gebruik van corticosteron als welzijnsindicator voor vleeskuikenouderdieren die worden gecontroleerd in de voeropname ter discussie. Het hormoon heeft namelijk een dubbele rol, namelijk als indicator van psychologische stress en van het metabolisme (Scanes, 2016 ). De Jong et al. (2003) meldde dat plasmacorticosteron sterk toenam wanneer de voercontrole meer dan $50 \%$ t.o.v. van ad libitum gevoerde dieren bedroeg, maar het verschil in de concentratie tussen 70 en $90 \%$ controle niveaus ten opzichte van ad libitum was niet significant. De Jong et al. (2002) gaf aan dat gecontroleerd gevoerde vleeskuikenouderdieren hogere corticosteron waarden hadden dan de ouderdieren die ad libitum werden gevoerd. Geen effecten van gecontroleerd gevoerde dieren t.o.v. ad libitum gevoerde dieren op corticosteron niveaus werd echter gevonden door Katanbaf et al. (1989) en Sandilands et al. (2005, 2006). De Jong et al. (2002) vermeldden verder dat de corticosteron concentraties varieerden afhankelijk van de leeftijd en het tijdstip van de dag en de tijd ten opzichte van het moment van voer verstrekken. Om deze reden is de waarde van de plasma corticosteron concentratie als welzijnsindicator twijfelachtig voor vleeskuikenouderdieren waarbij wordt gevarieerd in de hoeveelheid verstrekt voer. Bovendien kan het plasma corticosteron ook toenemen door stimuli die door het dier als bedreigend wordt ervaren, maar weinig effect hebben op het algehele welzijn, zoals het oppakken van dieren. Daarom wordt in onderzoek zo snel mogelijk na vangen (binnen 2 minuten) een bloedmonster genomen omdat binnen die tijd de respons op hanteren nog niet zichtbaar is in het bloed. Het is beter om naar chronische stressniveaus moet kijken in plaats van puntmetingen om te kijken of er sprake is van chronisch verhoogd corticosteron. Het lastige is dat het metabolisme een rol speelt bij de concentraties en dat het daarom bij vleeskuikenouderdieren met diverse voerbehandelingen lastig om te achterhalen waardoor het verhoogde corticosteron wordt veroorzaakt (I. de Jong, persoonlijke mededeling). 
In het algemeen is het vanwege de relatie met het metabolisme, dat voorzichtig moet worden omgegaan met de interpretatie van corticosteron als welzijnsindicator (de Jong et al., 2002; D'Eath et al., 2009; van Krimpen en de Jong, 2014).

Hematologische metingen (afwijkingen in bloed) zijn indirecte metingen van de stressreactie die aanvullende informatie kunnen geven over het optreden van langdurig stressvolle omstandigheden (Scanes, 2016; Jovani and Rohwer, 2017). Het aantal heterofielen en basofielen in verhouding tot het aantal lymfocyten worden beschouwd als indicator voor chronische stress (Hocking et al., 1996). De hematologische metingen worden vaak gerapporteerd als het aandeel leukocyten, als de verhouding tussen heterofielen/lymfocyten $(H / L)$ en/of als verhouding tussen basofielen/lymfocyten (B/L). Onder chronisch stressvolle omstandigheden namen de $\mathrm{H} / \mathrm{L}$ - en $\mathrm{B} / \mathrm{L}$-verhoudingen toe als gevolg van hogere poporties heterofielen en basofielen en een lagere proporties lymfocyten in het bloed (Hocking et al., 1996; Savory et al., 1996; Hocking et al., 2001). Gecontroleerd gevoerde vleeskuikenouderdieren hadden een significant hogere $\mathrm{H} / \mathrm{L}$-verhouding $(0,56-0,76)$ tijdens de opfokperiode in vergelijking met ad libitum gevoerde dieren (Hocking et al., 2001; Sandilands et al., 2006). Hocking et al. (1996) gaf aan dat naarmate de mate van voercontrole steeg bij opfok vleeskuikenouderdieren, zowel de corticosteronconcentratie en de $\mathrm{H} / \mathrm{L}$ ratio toenamen Daarmee suggereerde zij dat voercontrole zowel stress op de korte als op de lange termijn geeft. Bovendien wordt een groot aandeel van de basofielen $(10 \%)$ toegeschreven aan stressvolle omstandigheden zoals voercontrole bij vleeskuikenouderdieren (Hocking et al., 2001; Savory et al., 1996).

\subsection{Effecten op gedrag}

\subsubsection{Stereotiep pikgedrag}

Kippen zijn omnivoren die zowel zaden en kruiden als kleine insecten (wormen en insecten) eten voor de energie- en eiwitopname (Savory et al., 1978). Binnen het gedragsprofiel van kippen gerelateerd aan voeding kan onderscheid worden gemaakt in een voedsel-zoek-fase en een voedsel-eet-fase. Tijdens het voedsel zoeken schrapen kippen op een kenmerkende manier met de poot over de grond en pikken vervolgens naar eetbare ingrediënten (scharrelen en foerageren). Uit onderzoek blijkt dat onder (semi)natuurlijke omstandigheden kippen 60 tot $90 \%$ van hun tijd gedurende de dag aan eten en voedsel zoekgedrag besteden (Woodgush et al., 1978; Keeling, 2002; Appleby et al., 2004). Onder praktijkomstandigheden wordt tussen de 25 en $45 \%$ van de actieve tijd aan foerageren besteed (Appleby et al., 1989, 2004).

Kippen (en dus ook vleeskuikenouderdieren) gebruiken een groot gedeelte van de dag hun snavel tijdens het uitvoeren van gedrag (Arrazola et al., 2020). Plastisch gezegd komt dit waarschijnlijk doordat kippen geen handen hebben, de snavel fungeert als het ware als een hand en is het voornaamste middel om gedrag uit te voeren. Verder hebben kippen smaak- en nutriëntensensoren in hun snavel om hun voedingskeuze te sturen (Cho, 2019). Daarmee kunnen ze potentieel voedsel selecteren op smaak maar ook op de soort nutriënt (koolhydraten, vet, eiwit en mineralen). In de eerste plaats pikken de dieren om voedsel op te nemen, terwijl ze de snavel ook gebruiken bij het foerageren, bij het exploreren van objecten en omgeving en bij het onderhoud van het verenpak en stofbaden. Door een verminderde voerhoeveelheid aan de dieren te verstrekken, verandert de verdeling van het tijdsbudget gespendeerd aan diverse gedragingen. Een toenemend niveau van voercontrole, en daardoor kortere tijd die wordt besteed aan voeropname, resulteert in een langere tijd besteed aan foerageren (voedselzoek- en voedselopnamegedrag) en objectpikken (Hocking et al., 1996; van Emous et al., 2013, 2015a).

Uit experimenten is gebleken dat voercontrole bij vleeskuikenouderdieren resulteert in afwijkend gedragingen dat indicatief kan zijn voor honger en frustratie. Onder chronische omstandigheden kunnen deze gedragingen zich ontwikkelen tot abnormaal stereotiep gedrag (Mellor et al., 2018). Dit uit zich dan in stereotiep pikgedrag naar objecten en een hoge wateropname (Kostal et al., 1992; Savory et al., 1993; Hocking et al., 1996, 2001). Stereotiep pikgedrag wordt omschreven als repetitief gedrag, onveranderlijk van vorm, zonder duidelijk doel of functie (Mason, 1991; Mason et al., 2006). 
Het is een vorm van abnormaal gedrag en wordt algemeen beschouwd als een indicator voor verminderd welzijn (de Jong and Jones, 2006; D'eath et al., 2009). Onder stereotiep objectpikken verstaan we het pikken naar lege voersystemen, lege drinksystemen, muur en (gaas)wand.

Gedragswetenschappers gaan ervan uit dat de voercontrole frustrerend is voor de dieren, wat zich uit in stereotiep pikgedrag. In bijvoorbeeld een studie met gecontroleerd gevoerde opfok ouderdieren van 8 weken leeftijd vond men dat deze dieren ongeveer $40 \%$ van de actieve tijd naar de lege voerbak pikten (de Jong et al., 2002). In een studie van van Emous et al. (2015a) vond men gedurende de dag een toename van 15 naar 30\% stereotiep pikgedrag (met name naar de lege voerpannen) bij dieren die standaard opfokvoer kregen. Daarentegen namen zij minder stereotiep pikgedrag waar (van 1 naar maximaal $10 \%$ ), wanneer dieren een laag ruw eiwit voer verstrekt kregen. Dit kwam waarschijnlijk doordat de dieren een hogere voergift kregen en mede daardoor de voeropnametijd flink langer was.

De oorzaak van het pikken naar een leeg voersysteem kan naast omgericht foerageergedrag, ook komen doordat er nog resten van het voer in het systeem achter zijn gebleven (R.A. van Emous, persoonlijke observatie). In bijvoorbeeld een voersysteem met voerpannen kan een klein restant voer achterblijven in de aanvoervijzel met als gevolg dat dieren die op de pannen of vijzel pikken beloond worden met een kleine hoeveelheid voer wat conditioneren tot blijven pikken tot gevolg heeft.

Aan de andere kant, kan het ook een indicatie zijn van een sterke voeropname motivatie om zo veel mogelijk te pikken naar alle kleine voerresten.

Uit het onderzoek van van Emous (2015) blijkt verder dat er een negatieve relatie is tussen de tijd besteed aan eten en objectpikken (Figuur 17). Wanneer opfok ouderdieren meer tijd besteden aan eten, besteden ze minder tijd aan stereotiep objectpikken. Verder bleek dat deze relatie onafhankelijk is van de leeftijd. Het absolute niveau van stereotiep objectpikken nam toe tijdens het ouder worden, echter dit werd veroorzaakt door de hogere voercontrole en dus minder tijd besteed aan eten.

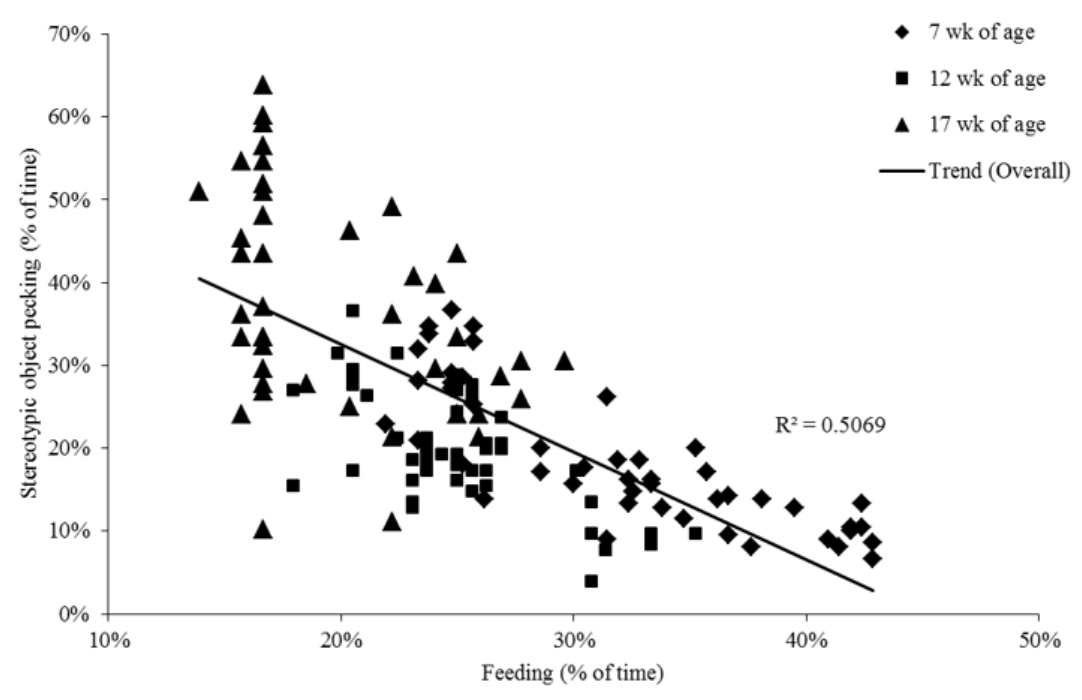

Figuur 17 Relatie tussen tijdsbesteding aan eten en stereotiep objectpikken (\% van de tijd) (van Emous, 2015).

Dit resultaat was een bevestiging van de conclusie van Mason et al. (2006) die ook de correlatie van tijdbesteding tussen voeropname en stereotiep objectpikken vond. Dit fenomeen van uitwisseling van gedrag kan worden verklaard door de 'wet van communicerende vaten' en dit principe is weergegeven in Figuur 18. In de figuur is voor het inzicht alleen het voeropname en stereotiep pikgedrag weergeven en zijn de andere gedragingen (staan, zitten, lopen, drinken, foerageren, verzorging) niet meegenomen. Het totale gedrag is $100 \%$, en wordt door de verschillende voeders in verschillende mate uitgevoerd; gedrag wordt dus als het ware uitgewisseld. De dieren bij het laag eiwitvoer kregen meer grammen voer en vertoonden langer voeropnamegedrag en dit verminderde en vertraagde het stereotiep objectpikken, in vergelijking met het hoog eiwitvoer. 


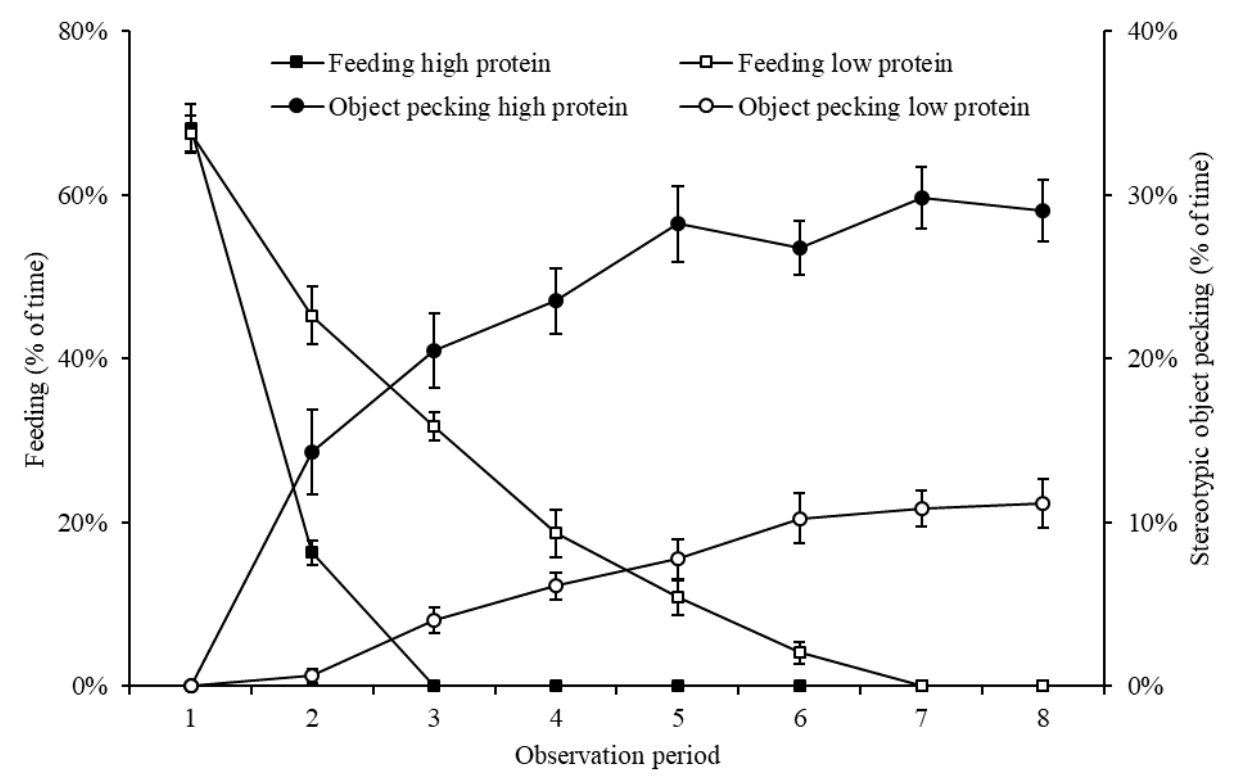

Figuur 18 Ontwikkeling van het voer en stereotiep pikgedrag (\% van tijd) gedurende de dag (van Emous, 2015).

Tijdens de piek voergift in de legperiode besteden de dieren tot vier uur per dag aan eten (ca. 165 tot 170 gram per dier meer dag). Aan het einde van de productie tot 60 weken leeftijd is dit ongeveer drie uur (de Jong en van Emous, 2017). De effecten op het gedrag nemen tijdens het begin van de legperiode snel af door de verminderde voercontrole waardoor ze minder stereotiep objectpikken en naar het strooisel pikken (Sandilands et al., 2005). Van Emous et al. (2015a) observeerde een zevenmaal lagere niveau aan objectpikken tijdens de leg- t.o.v. de opfokperiode. Daarnaast vonden zij nauwelijks verenpikken tijdens de legperiode. Vergelijkbare resultaten werden gevonden door de Jong et al. (2005b). De belangrijkste uitdagingen op het gebied van gedrag en welzijn liggen daarom bij vleeskuikenouderdieren vooral in de opfokfase (Arrazola, 2018).

\subsubsection{Verenpikken en verenlikken}

Zacht verenpikken en stereotiep verenlikken kan wijzen op afwijkend gedrag (Dixon et al., 2008). Zacht verenpikken wordt gedefinieerd als acuut pikken naar veren van een ander dier zonder dat de veer wordt verwijderd of een reactie van het slachtoffer optreedt (Hocking et al., 2005; Newberry et al., 2007; Dixon et al., 2008; de Jong et al. al., 2013). Bij ouderdieren is de incidentie van zacht verenpikken, in vergelijking met leghennen, relatief laag. Ook hard verenpikken, waarbij de veer uit het verenkleed getrokken wordt, komt bij ouderdieren weinig voor in tegenstelling tot leghennen. Stereotiep pikgedrag dat zich richt op het verenkleed van soortgenoten of zichzelf kan resulteren in slechte bevedering (Morrissey et al., 2014; Arrazola et al., 2019) en soms tot schadelijk verenpikken (Savory et al., 1993). In het algemeen wordt ernstig verenpikken bij ouderdieren nauwelijks waargenomen (de Jong en van Emous, 2017). In het onderzoek van van Emous et al. (2014, 2015a) was het aandeel verenpikken (en staartlikken) naar andere dieren tijdens de opfokperiode in het eerste en tweede experiment respectievelijk $5 \%$ en $0,5 \%$, terwijl het tijdens de legperiode verwaarloosbaar was.

In het algemeen beperkt het stereotiep pikgedrag bij opfok vleeskuikenouderdieren zich met name tot de veren van de staart en wordt omschreven als veren- of staartlikken (Nielsen et al., 2011; van Emous et al., 2015a). Dit stereotypisch verenlikken wordt vooral waargenomen in de periode tussen 15 en 25 weken leeftijd (Nielsen et al., 2011). Dit is na de periode (7 tot 16 weken leeftijd) dat de dieren het zwaarst gecontroleerd gevoerd worden (Savory et al., 1993; de Jong en Jones, 2006). Dit gedrag is in de eerste plaats te herkennen aan de activiteit zelf maar ook aan de wat donkere en vuilere veren aan de staart (Nielsen et al., 2011). In experimenten en in de praktijk wordt dit gedrag niet bij alle koppels waargenomen en ook niet in dezelfde mate. In de (wetenschappelijke) literatuur worden dan ook nauwelijks oorzaken genoemd. 
Er wordt wel gesuggereerd dat de dieren dit gedrag vertonen doordat de dieren een tekort hebben aan energie uit het voer. Uit onderzoek van Sandilands et al. $(2004 a, b)$ is gebleken dat de stuitklier (preen gland) diverse soorten vetzuren en esters afgeeft. Deze stoffen worden gebruikt voor het waterdicht maken van het verenkleed, helpt de conditie van de veren te behouden (Thompson, 1964) en werkt tevens als een antimicrobieel middel (Stevens, 1996). Er wordt ook gesuggereerd dat de zouten in de oliën vanuit de stuitklier een trigger zijn om dit van de staartveren af te likken (R.A. van Emous, persoonlijke mededeling). Mogelijk dat individuele dieren deze vetzuren eerst bij zichzelf opnemen en dat dit aanleiding is voor anderen om dit na te doen. Regelmatig wordt het verenlikken namelijk als groepsgedrag waargenomen (R.A. van Emous, persoonlijke observatie).

\subsubsection{Waterpikken}

Stereotiep pikken naar de drinkers en water kan leiden tot overmatig drinken (Savory et al., 1993a; Hocking et al., 2001) en vermorsen van water (Sandilands et al., 2005; Arrazola et al., 2019). Echter in de meeste experimenten waarin overmatig drinken en watervermorsing worden vermeld was er sprake van het gebruik van open watersystemen soms in combinatie met een langere daglengte (en dus langere periode met toegang tot water). In moderne proefaccommodaties voor opfok ouderdieren worden drinknippels met lekbakjes gebruikt terwijl in oudere studies open watersystemen werden gebruikt (Kostal et al., 1992; Savory et al., 1993; Hocking et al., 1996, 2001). Voor hennen is de wateropname uit open watersystemen veel gemakkelijker dan uit drinknippels, wat een hogere wateropname veroorzaakt. Bovendien leidden open watersystemen tot meer watervermorsing in vergelijking met drinknippels, wat de wateropname ten onrechte verhoogd en waarschijnlijk ook gedeeltelijk de genoemde problemen met nat strooisel veroorzaakte in de experimenten van Kostal et al. (1992), Savory et al. (1993) en Hocking et al. (1996, 2001). De tweede verklaring is de veel langere (14 t.o.v. 8 uur) daglengte zoals gebruikt door Kostal et al. (1992) en Savory et al. (1993). Een langere periode onbeperkt water verstrekken, zeker in combinatie met open watersysteem, kan leiden tot dwangmatig drinken als middel tegen verveling.

In een recent experiment van van Emous en Mens (2019) zag men dat er geen verschil was in de wateropname bij opfok dieren die controle of verdund voer kregen. Er wordt daarom verondersteld dat de wateropname voor opfokdieren gemaximaliseerd werd vanwege de fysieke capaciteit van krop en het waterverzadigingsniveau en niet werd beïnvloed door voercontrole. Over het algemeen was de gemiddelde water/voeding-verhouding wel hoger ( $2,3 \mathrm{ml}$ water op $1 \mathrm{~g}$ voer) dan normaal wordt geadviseerd onder commerciële omstandigheden (Aviagen-EPI, 2017). Ondanks de hoger water/voerverhouding bleef de strooiselkwaliteit echter goed. Tijdens onderzoek door Aviagen-EPI waarbij al meerdere jaren onbeperkt water wordt verstrekt bij opfokdieren ziet men een water/voer verhouding tussen de 2,15 en 2,30 zonder grote problemen met de strooiselkwaliteit (J. Lesuisse, persoonlijke mededeling). Tussen de 5 en 7 weken leeftijd ziet men de strooiselkwaliteit meestal wel afnemen doordat de dieren meer drinkgedrag vertonen. Ook wordt aangegeven dat wanneer dan de wateropname gecontroleerd wordt verstrekt het obsessief drinkgedrag juist zal toenemen. Dan gaat het spreekwoord gelden: "Zuipers worden gemaakt en niet geboren". Rond die kritieke leeftijd is het zaak om regelmatig het strooisel handmatig of machinaal te bewerken waardoor het weer opdroogt.

\subsubsection{Lopen (pacing)}

Wanneer opfok ouderdieren gecontroleerd gevoerd worden, vertonen ze extra activiteit wat zich uit in meer loopgedrag (eventueel in stereotiepe vorm, het zogenaamde 'pacing') specifiek voor het voeren. Stereotyp lopen specifiek voor het voeren wordt in de literatuur genoemd als een indicator van honger in vleeskuikenouderdieren (de Jong et al., 2002). Met name in de oudere literatuur wordt aangegeven dat dit gedrag dat dit gedrag indicatief is voor honger en frustratie door het ontbreken van voedsel (Hocking et al., 1993, 1996; Savory en Maros, 1993; Savory en Kostal, 1996; Savory en Mann, 1997). Stereotiep lopen is positief gecorreleerd met het niveau van voercontrole (Savory en Maros, 1993; Hocking et al., 1996). De laatste jaren worden echter vraagtekens gezet bij de conclusie dat lopen voor het voeren indicatief is voor honger in vleeskuikenouderdieren. In een recent onderzoek werden opfok ouderdieren een- of tweemaal per dag gevoerd in combinatie met controle en verdund voer (van Emous et al., 2020). Men vond dat dieren die eenmaal per dag gevoerd werden meer zitgedrag (rustgedrag) vertoonden tussen 12:00 en 15:00 uur dan de dieren die tweemaal per dag werden 
gevoerd. Dit was opmerkelijk omdat de behandelingen random verdeeld waren over de afdelingen. De dieren die alleen in de ochtend gevoerd werden, zagen en hoorden dat dieren in andere hokken (vaak ook direct naast het eigen hok) 's middags nog een keer voer kregen en reageerden daar dus niet op door actief gedrag te vertonen. Het verschil in gedrag gedurende de dag was ook zichtbaar rond 15 minuten voor de tweede voerbeurt. Meer dieren die tweemaal per dag gevoerd werden, vertoonden op dat moment loopgedrag dan de dieren die eenmaal per dag gevoerd werden. In het algemeen is het zo dat loopgedrag voorafgaand aan voer verstrekken normaal gedrag is dat bij de meeste dieren wordt waargenomen. Onder invloed van gewenning weten de dieren dat ze op korte termijn voer krijgen, en reageren daar op door actief te worden, ze gaan heen en weer lopen in afwachting van het voer (anticipatie gedrag). Het is daarom de vraag of het loopgedrag voor het voeren wel een indicator van honger is, of dat het gedrag is dat hoort bij de verwachting dat de dieren voer krijgen. Dit gedrag wordt namelijk ook waargenomen bij gezelschapsdieren en andere landbouwdieren waarbij het voer niet of nauwelijks gecontroleerd verstrekt word.

\subsubsection{Voeropnamemotivatie}

In een experiment van Savory en Lariviere (2000) vond men een positieve correlatie tussen hogere voercontrole en hogere voeropnamemotivatie. Dit werd bevestigd door onderzoek van Sandilands et al. (2005) en Tolkamp et al. (2005) die vleeskuikenouderdieren ad libitum voer verstrekte verdund met haverdoppen (met daarnaast calciumpropionaat). Verder vond men dat stereotiep pikgedrag vrijwel afwezig was, en dat de tijd die de dieren besteden aan zitten aanzienlijk toenam. In een experiment nam men waar dat opfok ouderdieren van 10 weken leeftijd sneller naar het voer renden bij sterkere voercontrole (Buckley et al., 2011). Men gaf ook aan dat door de sterke voercontrole de dieren mogelijk niet goed in staat zijn om bepaalde taken aan te leren.

In een onderzoek werd de relatie tussen voedermotivatie en de incidentie van grondeieren bij vleeskuikenouderdieren getest (Sheppard en Duncan, 2011). Men toonden op die manier aan dat de motivatie om een beperkte hoeveelheid voer op te nemen tijdens de productieperiode, waarbij het restrictieniveau veel lager is in vergelijking met de opfokperiode, nog steeds hoog was. Hennen die het commerciële voer kregen, verlieten het legnest tijdens het leggedrag wanneer het voer werd verstrekt (Sheppard en Duncan, 2011).

\subsection{Effecten op (re)productie en gezondheid}

Een gecontroleerde voeropname die de toename van het lichaamsgewicht controleert, geeft een verbetering van de ontwikkeling en het functioneren van het voortplantingssysteem (Arrazola, 2018). Voercontrole bij vleeskuikenouderdieren verminderd multi-ovulaties, resulterend in dubbeldooiers, reguleert een normale follikelhiërarchie en verbetert het percentage succesvolle paringen (Mench, 2002; Hocking, 2004). Minder dubbeldooiers geeft minder prolaps (uitstulping van de cloaca) en daardoor minder uitval in het begin van de legperiode (A. Steentjes, persoonlijke mededeling).

Het niveau van voercontrole tijdens het opfokken kan echter ook een nadelig effect hebben op de eierproductie als gevolg van chronische stress door voercontrole (Jones en Boissy, 2011). Het langetermijneffect van chronische stress tijdens gebeurtenissen in het vroege leven op de reproductieve prestaties is nog niet goed onderzocht (Naguid et al., 2006; Burton en Metcalfe, 2014). Hoewel mechanismen onbekend zijn, kan plasmacorticosteron een directe invloed hebben op het functioneren van de geslachtsorganen (Deviche et al., 2017). Voercontrole gaat gepaard met een verbetering van de eierproductie in vergelijking met ad libitum gevoerde vleeskuikenouderdieren, maar een te strenge voercontrole tijdens het opfokken kan dus ook hetzelfde negatieve effect hebben. Voercontrole bij vleeskuikenouderdieren resulteert in ieder geval in een volwassen lichaamsgewicht en een optimale skeletgrootte, met een volwassen lichaamssamenstelling (voldoende eiwitgehalte bij een verminderd vetgehalte) op volwassen leeftijd voorafgaand aan seksuele rijping of ontwikkeling van het voortplantingssysteem (Leeson en Summers, 1982; de Beer en Coon, 2007, 2009; Renema et al., 2001a, 2001b; Zuidhof et al., 2015; Vignale et al., 2016).

Voercontrole bij dieren die 70\% van de ad libitum voeropname verstrekt kregen tussen 8 en 14 dagen leeftijd, resulteerde in een lager aandeel vetweefsel tot de leeftijd van 35 dagen in vergelijking met 
dieren die ad libitum werden gevoerd (van der Klein et al., 2016). Een lager aandeel vetweefsel is gunstig voor de energiebehoefte omdat voor de opbouw van vetweefsel meer energie nodig is (energie inhoud van vet is hoger dan van eiwit). Vroege opfok is een gevoelige periode voor de ontwikkeling van het skelet (de Beer en Coon, 2007, 2009). Een slechte skeletontwikkeling kan de eiergrootte in gevaar brengen vanwege fysieke beperkingen. Om deze reden worden opfok vleeskuikenouderdieren vaak ad libitum gevoerd tijdens de eerste weken (Aviagen, 2016a, Cobb, 2016). De grootte van het skelet wordt indirect gemeten door te kijken naar de lengte van loop- en borstbeen en naar het aandeel van het asgehalte in het droge lichaamsgewicht (Leeson en Summers, 1985; Bennet en Leeson, 1989; de Beer en Coon, 2007, 2009; Zuidhof et al., 2015). Hoewel onderzoek dat kijkt naar het effect van skeletafmetingen op de reproductieve prestaties beperkt is, merkten Leeson en Summers (1985) op dat vleeskuikenouderdieren die werden opgefokt bij een skip-a-day programma, een korter loop- en borstbeen hadden tijdens de opfokperiode. Tevens legden deze dieren minder eieren met een slechtere eischaalkwaliteit vergeleken met degenen die dagelijks voer kregen. De Beer en Coon (2009) vonden dat opfok ouderdieren die tot 6 weken leeftijd ad libitum werden gevoerd, langere borstbenen en loopbenen hadden met een hoger asgehalte dan de dieren die voerprogramma's (skip-a-day, 4-3, 5-2) volgden. Voercontrole kan tijdens de vroege ontwikkeling de groeisnelheid, de lichaamssamenstelling en de skeletontwikkeling (negatief) beïnvloeden, wat op de lange termijn mogelijk negatieve gevolgen heeft op de eiproductie.

De periode tussen 7 en 15 weken leeftijd is een kritieke periode om het lichaamsgewicht onder controle te houden (Bruggeman et al., 1999). Om deze reden is de voercontrole het hoogst in deze fase van de opfokperiode (Savory et al., 1993; de Jong en Jones, 2006). Bruggeman et al. (1999) gaf aan dat onbekende factoren tijdens deze midden periode van de opfok toekomstige legprestaties kunnen beïnvloeden. Overmatig vetweefsel kan bijvoorbeeld de endocriene regulatie van de hypothalamus-hypofyse-gonadale as verstoren, waarbij de voortplantingsorganen minder gevoelig zijn voor hypofyse-vrijgemaakte seksuele hormonen (LH en FSH) bij obese jonge opfokdieren (Arrazola, 2018). Deze resultaten wijzen op de cruciale rol van voeding tijdens de opfok om de ontwikkeling van vetweefsel te beperken.

De late opfok periode (ca. 16-22 weken leeftijd) is erg belangrijk voor de ontwikkeling van de voortplantingsorganen (eierstok en eileider) en (matig) vetweefsel om de start van de eiproductie te ondersteunen. Bruggeman et al. (1999) geeft in hun onderzoek aan dat de seksuele ontwikkeling bij vleeskuikenouderdieren begint tijdens de late opfok periode, en voercontrole kan tijdens deze periode de ontwikkeling van de geslachtsorganen negatief beïnvloeden. Het niveau van de voercontrole en dus de groeisnelheid van de dieren kan inderdaad de seksuele ontwikkeling en het begin van het leggen vertragen (Bruggeman et al., 1999; Renema et al., 2001a; Heck et al., 2004). Bovendien kan chronische stress tijdens de seksuele ontwikkeling negatieve carry-over effecten geven op productie en gezondheid tijdens de legperiode (Odihambo Mumma et al., 2004; Deviche et al., 2017). Het niveau van de voercontrole neemt af aan het einde van de opfokfase, waardoor de voeding tijdens deze periode een directe invloed heeft op de ontwikkeling van de voortplantingsorganen, wat leidt tot een langdurig effect op de reproductie prestaties (Bruggeman et al., 1999).

Toepassen van voercontrole tijdens de opfokperiode heeft ook effect op de lichaamssamenstelling van de dieren (Bennet en Leeson, 1990; Sun et al., 2006; Robinson et al., 2007; Mba et al., 2010, van Emous et al., 2013, 2015b). In het onderzoek van van Emous et al. (2013, 2015b) werden op 15 weken leeftijd geen effecten van het eiwitgehalte in het voer op het buikvet\% gevonden, terwijl dit wel aanwezig was op 10 en 20 weken leeftijd. Dit fenomeen werd eerder ook gevonden door Mba et al. (2010) die op week 12 een verschil in buikvet\% waarnam dat werd beïnvloed door verschillen in eiwitgehalte in het voer, terwijl dit verdwenen was op 19 weken leeftijd. Het lijkt erop dat de ontwikkeling van het buikvet\% en het totaal vetgehalte van het lichaam een specifiek patroon volgen tijdens de opfokperiode (Figuur 19). Dit patroon in lichaamssamenstelling werd eerder gerapporteerd door Bennet en Leeson (1990) die een verlaagd totaal vetgehalte tussen 2 en 14 weken leeftijd vonden, maar een verhoogd vetgehalte tussen 14 en 24 weken leeftijd. 


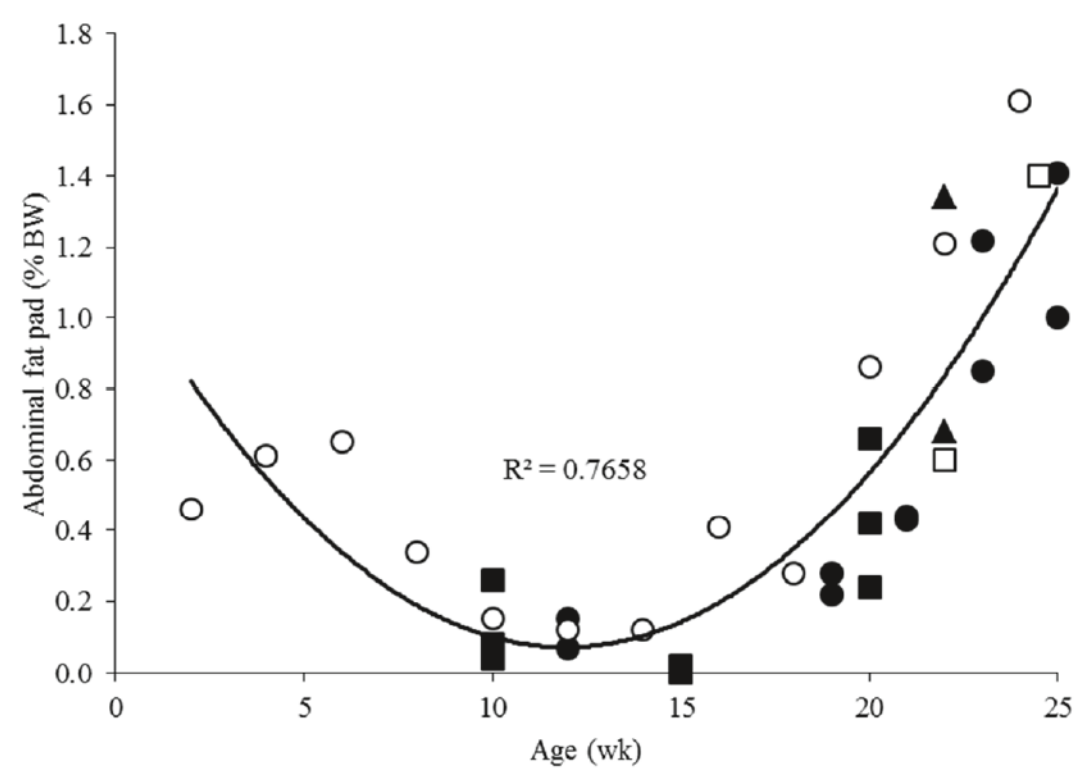

Figuur 19 Relatie tussen leeftijd en buikvet (\%) tijdens de opfok- en begin legperiode (van Emous, 2015). Verschillende tekens betekenen dat de data afkomstig is van verschillende bronnen.

Uit onderzoek is gebleken dat een zekere mate van vetontwikkeling aan het einde van de opfokperiode nodig is voor een goede start van de productie en productie persistentie in de tweede helft van de legperiode (de Beer, 2009; van Emous et al., 2015b; Zuidhof, 2018). Uit het onderzoek van van Emous (2015) bleek dat een hoger buikvet gehalte aan het einde van de opfokperiode resulteerde in een verbeterde legpersistentie vanaf ca. 48 weken leeftijd (Figuur 20). Dit werd veroorzaakt doordat de dieren die tijdens de opfokperiode gevoerd werden met een hoog of laag eiwitvoer, verschillen lieten zien in buikvetgehalte. De dieren die het laag eiwitvoer verstrekt kregen, namen meer grammen voer op wat een hogere energieopname gaf. De dieren die het laag eiwitvoer verstrekt kregen, hadden op 22 weken leeftijd 1,34\% buikvet en 17,4\% borstfilet en bij de dieren die het hoog eiwitvoer verstrekt kregen, was dit $0,68 \%$ en $20,2 \%$. Uit de analyse bleek dat het buikvet percentage op 22 weken leeftijd belangrijker was dan het borstfilet\% voor een goede legpersistentie in de tweede helft van de legperiode.

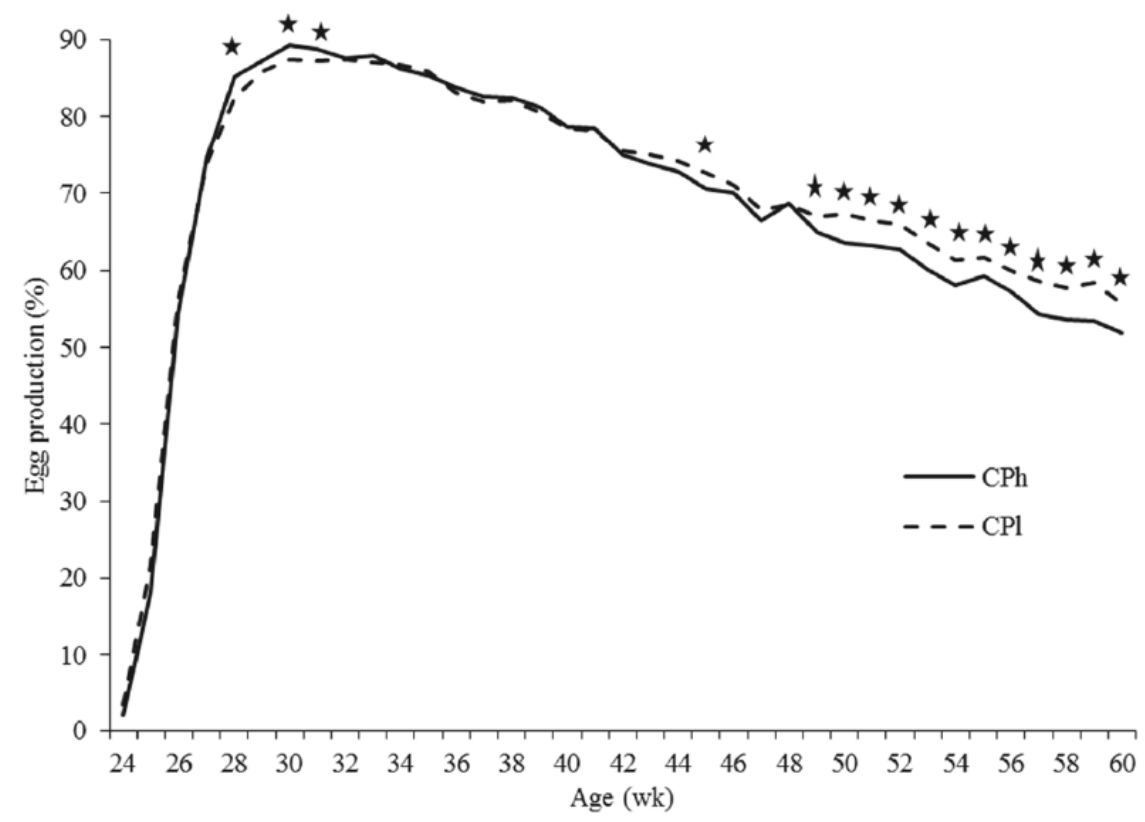

Figuur 20 Het effect van het toepassen van een hoog (CPh) of laag eiwitvoer (CPI) tijdens de opfokperiode op de eiproductie. 


\subsection{Samenvatting effecten voercontrole}

Uit de literatuur blijkt dat het gebruiken van de plasma corticosteron concentratie twijfelachtig is als welzijnsindicator voor vleeskuikenouderdieren. Plasma corticosteron kan namelijk ook toenemen bij bedreigende stimuli zoals het oppakken van dieren. Daarnaast is het zo dat het voerniveau op zich ook het plasma corticosteron niveau kan beïnvloeden en men dus niet zeker weet of men metabole of stress effecten aan het meten zijn.

Hematologische metingen (verhouding heterofielen en basofielen t.o.v. lymfocyten: H/L en B/L ratio's) zijn indirecte metingen van de stressreactie die aanvullende informatie kunnen geven over het optreden van chronische stress en lijken geschikter als welzijnsindicator.

Stereotiep pikgedrag naar objecten en de staart (staartlikken) lijken betrouwbare indirecte welzijnsindicatoren omdat er een directe relatie lijkt te zijn tussen de mate van voercontrole en stereotiep objectpikken. Met name het verenlikken aan de staart is heel specifiek voor ouderdieren in de periode dat ze het sterkst gecontroleerd gevoerd worden. Aan de andere kant kan het staartlikken ook te maken hebben met het opnemen van vet uit de stuitklier.

Stereotiep pikken naar een ogenschijnlijk leeg voersysteem is mogelijk geen betrouwbare welzijnsindicator. Doordat de dieren op bijvoorbeeld de lege voerpan of aanvoervijzel pikken komt er mogelijk wat restvoer vrij dat werkt als een beloning voor het pikgedrag. Aan de andere kant, kan het ook een indicatie zijn van een sterke voeropname motivatie om zo veel mogelijk te pikken naar alle kleine voerresten.

Het pikken naar water en hogere wateropname is geen goede welzijnsindicator bij vleeskuikenouderdieren omdat in oudere experimenten de hoge wateropname veroorzaakt werd door een langere daglengte en/of open watersysteem.

Actief loopgedrag voor het voeren is mogelijk geen goede welzijnsindicator omdat dit normaal gedrag is bij alle dieren die weten dat ze voer krijgen.

Voercontrole bij vleeskuikenouderdieren geeft minder dubbeldooiers en daarmee een lagere kans op prolaps (uitstulping van de cloaca) en uitval. Daarnaast zorgt voercontrole ervoor dat de dieren niet te vroeg in productie komen waardoor ze meer persistent zijn en langer productief blijven.

Voercontrole bij de huidige ouderdieren geven echter minder vetreserve bij de start van de legperiode waardoor ze minder persistent zijn. Aanpassing van de energie/eiwit ratio tijdens de opfokperiode kan dit oplossen. 


\section{$5 \quad$ Vermindering effecten voercontrole}

\section{$5.1 \quad$ Ad libitum voeding}

De meest logische methode om de effecten van voercontrole te verminderen is door geen voercontrole meer toe te passen. Er zijn diverse experimenten uitgevoerd om na te gaan of het mogelijk is vleeskuikenouderdieren ad libitum voer te verstrekken. Uit deze experimenten bleek echter dat het ad libitum verstrekken van voer, resulteerde in zeer snelle groei, een hoog lichaamsgewicht en als gevolg daarvan gezondheidsproblemen (pootproblemen en verhoogde uitval) en reproductieproblemen (Hocking et al., 1989; Katanbaf et al., 1989; Mench, 2002; Heck et al., 2004; Sahraei, 2012). Deze problemen werden in verband gebracht met negatieve neveneffecten zoals ongemak, pijn, ziekte en zwakte (Mellor, 2016). In het onderzoek van Heck et al. (2004) nam de uitval sterk toe tot $40 \%$ (40 of 50 weken leeftijd) bij de ad libitum gevoerde dieren versus $6 \%$ bij de gecontroleerd gevoerde dieren. In een ouder onderzoek van Katanbaf et al. (1989) vond men dat ad libitum gevoerde vleeskuikenouderdieren een hogere uitval hadden vanaf ongeveer $4 \mathrm{~kg}$ lichaamsgewicht, met een sterftecijfer van respectievelijk 50 en $70 \%$ op 52 en 66 weken leeftijd. Heck et al. (2004) vergeleken ad libitum en gecontroleerd gevoerde vleeskuikenouderdieren in twee experimenten tot 40 en 50 weken leeftijd. Het toepassen van gecontroleerde voeding vertraagde de seksuele volwassenheid met zes weken en de piekproductie met zeven tot acht weken. De maximale legpercentages waren $57,0 \%$ voor de dieren die ad libitum werden gevoerd en $83,3 \%$ voor de dieren die gecontroleerd werden gevoerd. De gecontroleerde gevoerde ouderdieren vertoonden een goede persistentie, terwijl het legpercentage van de ad libitum gevoerde groep na de lage piekproductie snel afnam tot minder dan 25\% (Heck et al., 2004).

Ad libitum gevoerde vleeskuikenouderdieren ontwikkelen overmatig vetweefsel, wat resulteert in een slechte reproductie. Resultaten van Bruggeman et al. (1999) laten zien dat voercontrole voorafgaand aan de ontwikkeling van voortplantingsorganen noodzakelijk was om optimale reproductie resultaten tijdens de leg te bereiken. Gelijkwaardige resultaten werden gerapporteerd door de Beer et al. (2009). De auteurs vonden uitstekende reproductie resultaten van vleeskuikenouderdieren die tot 6 weken leeftijd ad libitum gevoerd werden, gevolgd door gecontroleerde voeropname. Deze resultaten geven aan dat een gecontroleerde toename van het lichaamsgewicht van cruciaal belang is vanaf de leeftijd van 7 weken en gedurende de gehele productiecyclus. Om deze reden is een uniforme ontwikkeling van het lichaamsgewicht bij vleeskuikenouderdieren nodig om een optimale en winstgevende reproductie resultaten te bereiken. Dit kan worden bewerkstelligd door de energieopname te controleren voordat de geslachtsorganen zich ontwikkelen (Arrazola, 2018).

Een hoog lichaamsgewicht van ouderdieren op geslachtsrijpe leeftijd is in verband gebracht met het hoge aantal volwassen (gele) follikels in de eierstok (Heck et al., 2004) wat leidt tot een hogere incidentie van dubbeldooiers. Heck et al. (2004) gaf aan dat slechtere reproductieve prestaties van ad libitum gevoerde ouderdieren gedeeltelijk werden verklaard door een hoger aantal volwassen follikels en een zwaardere eierstok in vergelijking met ouderdieren die gecontroleerd gevoerd werden. Chen et al. (2006) ontdekten dat overmatig vetweefsel verantwoordelijk was voor de slechte reproductieve prestaties bij ouderdieren.

Lage eiproductie in combinatie met multi-ovulaties, versnelde geslachtsrijpheid, lage eikwaliteit en lage legpersistentie zijn bij ad libitum gevoede vleeskuikenouderdieren ook waargenomen door Hocking et al. (1989). De ad libitum gevoerde dieren legden een hoger aantal dubbeldooiers of eieren met een zachte of gebroken schaal wat resulteerde in een veel lager aantal $1^{\mathrm{e}}$ soort eieren.

Ook een te zwaar lichaamsgewicht van de hanen heeft invloed op de reproductie. Te zware hanen worden geassocieerd met verminderde paringssucces, wat leidt tot lagere bevruchting en uitkomst van de broedeieren (Mench, 2002). 


\subsection{Aangepaste gewichtsschema's}

Er zijn diverse studies uitgevoerd waarbij de opfokdieren op basis van verschillende gewichtsprofielen werden gehouden (Fattori et al., 1993; Hocking et al., 2001, Renema et al., 2001; Gous en Cherry, 2004, Sun en Coon, 2005; Zuidhof et al., 2007; van Emous et al., 2013; de los Mozos et al., 2017). Slechts in de laatste twee studies werden ook gedragsobservaties meegenomen terwijl de andere studies zich beperkten tot productie resultaten.

Van Emous et al. (2013) onderzochten de effecten van drie verschillende eiwitniveaus in de voeders en verschillende groeiprofielen ( 2.400 vs. $2.200 \mathrm{~g}$ op 20 weken leeftijd). De verhoogde voeropname $(6,5 \%)$ en de verlengde eettijd van de dieren die bij het $9 \%$ hogere gewichtsprofiel werden gehouden, verlaagden het stereotiepe objectpikken en het pikken naar andere dieren echter niet.

In het onderzoek van de los Mozos et al. (2017) werden dieren gehouden bij een 15\% hoger lichaamsgewicht. De dieren die volgens het hogere gewichtsprofiel werden gehouden, deden 19 minuten langer over de voeropname maar ook in dit onderzoek werden geen effecten op stereotiep pikgedrag gevonden.

Het voeren van de dieren volgens een hoger gewichtsprofiel gedurende de opfokperiode gaf een hoger buikvet gehalte op 20 weken leeftijd (van Emous et al., 2013). Daarentegen vonden Fattori et al. (1993) en Renema et al. (2001) geen effect van 15\% of $8 \%$ hogere gewichten op 20 weken leeftijd op het buikvetgehalte. Sun en Coon (2005) rapporteerden een verlaagd eiwitgehalte van het lichaam en geen verschillen in vetgehalte van de dieren wanneer het lichaamsgewicht $13 \%$ hoger was op 20 weken leeftijd. Een $9 \%$ zwaarder lichaamsgewicht aan het einde van de opfokperiode in onderzoek van van Emous et al. (2013) leidde niet tot een hoger gemiddeld eigewicht. Dit is in overeenstemming met de resultaten van Fattori et al. (1991) en Hocking et al. (2001, 2002), die ook geen effect vonden van een $8 \%$ en $20 \%$ hoger lichaamsgewicht op het gemiddelde eiergewicht.

Totaal aantal eieren en broedeieren werden niet beïnvloed door een hoger gewichtsprofiel (van Emous et al., 2013). Deze resultaten zijn in overeenstemming met die van Fattori et al. (1991), Hocking et al. (2002), Gous en Cherry (2004), Sun en Coon (2005) en Zuidhof et al. (2007). Ekmay et al. (2012) rapporteerden echter een hoger aantal eieren per opgehokte hen als gevolg van een $20 \%$ hogere lichaamsgewicht aan het einde van de opfokperiode. Er werd gesuggereerd dat dit veroorzaakt werd door een vroegere seksuele volwassenheid en een hogere piekproductie. Renema et al. (2001) vond de laagste totale eiproductie bij standaard lichaamsgewicht vergeleken met lichtere en zwaardere hennen.

\subsection{Dwergouderdieren}

In de literatuur wordt het gebruik van dwergouderdieren als oplossing voorgesteld, omdat deze dieren een relatief goede reproductie hebben bij ad libitum voeding (Decuypere et al., 2006, 2010). De nakomelingen van dwergouderdieren zijn nog steeds relatief snelgroeiende vleeskuikens als de hen wordt gekruist met een haan van een snelgroeiend ras. In het onderzoek van Heck et al. (2004) vond men dat de productie van dwergouderdieren lager was dan die van reguliere gecontroleerde gevoerde moederdieren. Uit onderzoek is gebleken dat het vervangen van reguliere moederdieren met dwergmoederdieren het welzijn kan verbeteren. Dit komt met name door het ontbreken van de voercontrole en resulteert in voordelige positieve veranderingen in gedrag zoals minder stereotiep pikgedrag (Jones et al., 2004). In de literatuur wordt opgemerkt dat het verschil in grootte tussen de hen en haan voor problemen zou kunnen zorgen bij het paringsgedrag, wat kan leiden tot noodzakelijke kunstmatige inseminatie (Decuypere et al., 2010). In de praktijk blijkt dit echter niet het geval te zijn omdat de hanen als het ware over de hennen staan en niet zo zeer de hennen betreden (I. de Jong, persoonlijke mededeling). Daarnaast zijn dwergouderdieren gericht op een specifiek marktsegment en is het gebruik van deze dieren om economische redenen vaak niet wenselijk voor de pluimveehouder (de Jong en Guémené, 2011).

Een tweede genoemde oplossing is om meer langzaam groeiende rassen te gebruiken en een breder fokdoel te formuleren waarin welzijn is geïmplementeerd (Decuypere et al., 2010). Echter, gelijk aan de situatie van dwerghennen, zijn langzaam groeiende rassen vaak voor een specifieke marktvraag (de Jong en Guémené, 2011). 
Opgemerkt moet worden dat het vervangen van reguliere snelgroeiende vleeskuikens door langzaam groeiende vleeskuikens consequenties heeft m.b.t. het milieu, duurzaamheid (bijv. hogere voerconversie, hoger landgebruik, hogere uitstoot van $\mathrm{NH}_{3}$ en fijnstof), efficiëntie en andere niet welzijn gerelateerde aspecten. Uit deskstudies blijkt dat de milieubelasting van ouderdieren van langzaam groeiende vleeskuikens lager te zijn dan die van reguliere ouderdieren door de hogere productie en lagere voeropname (Rougoor en van der Schans, 2019; van Emous, 2019).

\subsection{Aanpassing voersamenstelling}

Een andere mogelijkheid die wordt onderzocht, is het aanpassen van de voersamenstelling. Door bijvoorbeeld meer voer met een lager niveau aan nutriënten (energie en eiwit/aminozuren) aan te bieden, zou de voercontrole kunnen worden beperkt. Een ander voorbeeld is het aanpassen van de energie/eiwit ratio in het voer (Sandilands et al., 2006, van Emous et al., 2014, 2015a). In de experimenten van van Emous et al. (2014, 2015a) onderzocht men de effecten van drie verschillende eiwit niveaus in de voeders en verschillende groeiprofielen $(2.400 \mathrm{~g}$ versus $2.200 \mathrm{~g}$ op de leeftijd van 20 weken) op indicatoren van welzijn tijdens de opfok- en productieperiode. Mede door de hogere voergift werd een positief effect op de welzijnsindicatoren gevonden bij het eiwitarme voer in de opfokperiode. Het stereotiep objectpikken in de opfokperiode was significant verminderd in het laag eiwitvoer in vergelijking met het hoog eiwitvoer (van Emous et al., 2014, 2015a). Sommige wetenschappers suggereren dat alternatieve voerstrategieën resulteren in een verbeterd dierenwelzijn door in te spelen op een natuurlijker voedingsgedrag en/of een gevuld gevoel (Zuidhof et al., 1995; de Jong et al., 2005a; Sandilands et al., 2006), anderen concluderen echter dat deze methode de 'metabolische honger' niet wegneemt (de Jong et al., 2005a; D'Eath et al., 2009). Daarnaast zijn er studies die helemaal geen positieve effecten op het gedrag en welzijn vonden als gevolg van alternatieve strategieën (Savory en Lariviere, 2000; Hocking et al., 2001; van Emous et al., 2020; Tahamtani et al., 2020). Bijvoorbeeld, Decuypere et al. (2006) concludeerden dat verstrekking van voer met veel vezels (een grotere massa voer met minder voedingswaarde) verwaarloosbare resultaten gaf op het dierenwelzijn. Het blijf echter lastig om een subjectieve staat zoals honger objectief en direct te meten. Meer onderzoek zal moeten uitwijzen welke parameters hier het meest geschikt voor zijn.

De conclusies binnen de wetenschap over de alternatieve voeders zijn tot op heden tegenstrijdig en meer onderzoek zal moeten uitwijzen wat de daadwerkelijke invloed van deze voeders is op het dierenwelzijn (D'Eath et al., 2009). Daarentegen lijken eetlustonderdrukkers (bijv. calciumpropionaat) in combinatie met ad libitum haverdoppen als alternatief voor de voercontrole een positief effect te hebben om het stereotiep pikgedrag en daarmee het dierenwelzijn van de ouderdieren te verbeteren (Tolkamp et al., 2005; Sandilands et al., 2005, 2006; Morrissey et al., 2014b; Arrazola et al., 2019). Dit alternatief zorgt ervoor dat ondanks ad libitum voerverstrekking, het gewenste groeipatroon wordt gevolgd. Objectpikken komt vrijwel niet voor $(<1 \%)$ bij voeders met calciumpropionaat in vergelijking met standaard voer (ca. 50\% van hun tijd). Er zijn echter aanwijzingen dat de dieren zich mogelijk ziek voelen door de eetlustonderdrukkers, wat niet positief is voor het welzijn van de dieren. Bovendien verschilden andere gedragsparameters en fysiologische parameters (zoals plasma corticosteron levels) niet in vergelijking met gecontroleerd gevoerde dieren (Sandilands et al., 2006). Arrazola et al. (2019) observeerde zelfs dat de dieren aversie tegen het voer ontwikkelde bij bepaalde gehalten aan calciumpropinaat.

\subsection{Voerfrequentie of voer strooien}

Het aanpassen van de voerfrequentie (tweemaal t.o.v. eenmaal per dag) tijdens de opfokperiode is door van de Haar en van Voorst (2001) onderzocht in combinatie met voer verstrekken via voerpannen of spinfeeder. De dieren die tweemaal per dag werden gevoerd, scharrelden, liepen en stonden minder dan de dieren die eenmaal per dag gevoerd werden. Opvallend was dat de concentratie van corticosteron in het bloedplasma op 12 weken leeftijd het hoogst was bij de hennen die tweemaal per dag werden gevoerd. Daarnaast was de uniformiteit op 13 weken leeftijd het laagst bij de hennen die tweemaal per dag werden gevoerd in voerpannen. De Jong et al. (2005a) onderzochten ook de effecten van tweemaal t.o.v. eenmaal per dag voer verstrekken met daarnaast 
het strooien van voer in het strooisel (spinfeeder) of voerpannen, op stress of honger in de opfokperiode. $\mathrm{Zij}$ vonden echter geen effecten van beide methoden op het gedrag en de fysiologische indicatoren van stress.

In de praktijk worden ouderdieren tijdens de legperiode normaal ook eenmaal per dag in de ochtend gevoerd. Door de dagportie te verdelen over meerdere maaltijden zou het voer beter verdeeld worden over de dag met mogelijk positieve effecten op productie, eigewicht en schaalkwaliteit (o.a. Spradley et al., 2008; Taherkhani et al., 2010; Moradi et al., 2013; Soltanmoradi et al., 2013).

Recent is een $2 \times 2$ factoriaal experiment met voersoort en voerfrequentie als behandelingen met opfok vleeskuikenouderdieren uitgevoerd (van Emous et al., 2020). De dieren die tweemaal per dag werden gevoerd vertoonden meer eet- en drinkgedrag, en minder zit- en verzorgingsgedrag, in vergelijking met dieren die éénmaal werden gevoerd. Verder neigden dieren die tweemaal per dag werden gevoerd naar meer foerageer gedrag dan de dieren die eenmaal per dag gevoerd werden. De verschillen in gedrag werden bevestigd door incidentele waarnemingen van de dierverzorgers tijdens het voeren in de middag. $\mathrm{Zij}$ zagen dat de dieren van de beide proefgroepen duidelijk anders reageerden op het betreden van de afdeling. De dieren in de hokken die de tweede voerbeurt kregen, liepen heen en weer, renden, fladderden en maakten geluid. De dieren die op dat moment geen voer kregen, gingen zonder al te veel te reageren door met scharrelen, zitten, staan en verzorging van het verenkleed. Het lijkt er sterk op dat de dieren 'geconditioneerd' werden door het ritme van voorgaande dagen waardoor ze op deze wijze reageerden. De dieren die 's middags voer kregen, koppelden de binnenkomst van de verzorger aan het voeren terwijl de dieren 's middags geen voer kregen die koppeling niet hadden. Het lijkt er dus op dat het gedrag rond het voeren te maken heeft met gewenning en verwachting op het verkrijgen van voer en mogelijk minder met hongergevoel. Echter is dit zonder het meten van fysiologische parameters niet met zekerheid te zeggen.

Naast de bovengenoemde gedragswaarnemingen, verbeterde tweemaal daags voeren de uniformiteit van het koppel (11,5\% vs. 14,2\% BW CV) op een leeftijd van 10 weken (van Emous et al., 2019). Op 20 weken leeftijd was dit verschil echter verdwenen. Dit was het tegenovergestelde van de resultaten van van der Haar en van Voorst (2001) die een slechtere uniformiteit vonden op 13 weken leeftijd wanneer hennen tweemaal per dag werden gevoerd. Deze discrepantie tussen het huidige en het voorgaande experiment (van der Haar en van Voorst, 2001) kan verklaard worden door de verschillen in voerstructuur (meel en pellets) en de verschillende rassen (Ross 508 en 308) die werden gebruikt.

\subsection{Mogelijke oplossingen}

Gezien het bovenstaande zijn er op dit moment geen kant en klare oplossingen om de effecten van voercontrole op gedrag, welzijn en reproductie op te lossen. Het stereotiep pikgedrag is een indicator van verminderd welzijn terwijl de voeropname motivatie van de dieren erg hoog is. Daarnaast is te beargumenteren dat het stereotiep pikgedrag mede ontstaat door een mismatch in tijdsbesteding doordat de dieren het voer te snel opnemen. Een combinatie van maatregelen om de voeropnametijd maximaal te verlengen om de gevolgen van voercontrole te verminderen, lijkt het meeste effect te genereren. Daarbij wordt gedacht aan het meerdere keren per dag voeren, verschillende methoden van voer verstrekken en verdund voer aanbieden. Er zal daarom gekozen moeten worden voor een multifactoriële oplossing waarbij bijvoorbeeld de dieren vaker per dag een kleine portie verdund voer verstrekt krijgen. Mogelijk dat nog vaker per dag voer verstrekken additionele effecten heeft op gedrag, welzijn en productie. Omdat het praktisch op dit moment moeilijk is om een kleine voerhoeveelheid in een praktijkstal netjes te verdelen zal men gebruik kunnen maken van een spinfeeder om het voer over het strooisel te strooien. Daarnaast zijn er mogelijk nog innovatievere oplossingen te bedenken om het voer snel te verdelen over het koppel en/of in een andere vorm aanbieden (bijv. grote brokken).

Een innovatieve manier van voer verstrekken is de laatste jaren in Canada ontwikkeld waarbij gechipte ouderdieren individueel gevoerd worden naar lichaamsgewicht om een zo goed mogelijke uniformiteit te bereiken (Zuidhof et al., 2017, 2018). Met het zogenaamde Precision Feeding Station worden kuikens op maat gevoerd en krijgen alleen voer wanneer hun lichaamsgewicht lager dan de norm is. Uit dat onderzoek bleek verder dat de dieren het station gemiddeld 17 maal per dag bezoeken en tijdens die bezoeken gemiddeld iets meer dan 4 maaltijden krijgen en dat ze per maaltijd gemiddeld 17 gram voer opnemen. Daarnaast bleek dat individuele dieren verschillend voeropname gedrag vertonen en dat sommige dieren het station meer dan 50 maal per dag bezoeken. 
Het toepassen van onbeperkt water verstrekken tijdens de opfokperiode kan een positieve bijdrage leveren aan de rust in het koppel dieren. In een recent experiment uitgevoerd door Wageningen Livestock Research (WLR) kregen alle dieren onbeperkt water aangeboden gedurende de lichtperiode (7 uur) tijdens de opfok (van Emous en Mens, 2019). Dit leidde tot een 28\% hogere water/voer verhouding $(2,3$ vs. de norm 1,8$)$ maar gaf geen problemen met de strooiselkwaliteit. Tijdens de daaropvolgende legperiode (met 9 uur water) was de water/voer verhouding 1,9 wat een indicatie is dat de dieren een normaal en rustig wateropname gedrag vertoonden. In experimenten door Aviagen bij het Spelderholt in Lelystad kregen de dieren ook probleemloos bijna de gehele dag water tijdens de opfokperiode (J. Lesuisse, persoonlijke mededeling). Ook die dieren hadden een verhoogde water/voer verhouding $(2,15$ tot 2,30$)$ en moest het strooisel wel regelmatig bewerkt worden om de strooiselkwaliteit goed te houden. In een ander experiment bij WLR werden dieren vanuit standaard opfok (met gecontroleerd water) gebruikt. Bij dit koppel ouderdieren werden grote problemen met wateropname gezien vanaf de start van het experiment (20 weken leeftijd). Deze dieren hadden niet geleerd dat er de gehele dag water beschikbaar was waardoor het gezegde, gebruikt bij mensen, lijkt op te gaan: 'dat zuipers niet worden geboren maar gemaakt'.

\subsection{Samenvatting vermindering effecten voercontrole}

Ad libitum voer verstrekken is niet mogelijk doordat de dieren grote problemen ondervinden met de gezondheid en reproductie door de extreme toename van het gewicht tijdens de opfokperiode. Uit de beperkte studies met voeren volgens verschillende gewichtsprofielen blijkt dat een 10 tot 15\% hoger eindgewicht geen positieve effecten geeft op gedrag ten opzichte van standaard voercontrole. Het grote voordeel van het toepassen van dwergouderdieren of ouderdieren van trager groeiende rassen is dat deze bijna, ook tijdens de opfokperiode, onbeperkt gevoerd kunnen worden zonder negatieve effecten op gezondheid en reproductie. Vleeskuikens van ouderdieren van trager groeiende rassen hebben echter nadelen op het terrein van duurzaamheid (People, Planet en Profit) door o.a. hogere voerconversie, hogere landgebruik, hogere uitstoot van $\mathrm{NH}_{3}$ en fijnstof. Het aanpassen van de voersamenstelling of het verdunnen van het totale voer (met vezels) en of gedeeltelijk (bijv. alleen eiwit of energie) kan helpen om de eettijd te verlengen en daarmee stereotiep pikgedrag te verminderen. Het toevoegen van eetlustonderdrukkers zoals calciumpropionaat) lijkt geen goede methode omdat de dieren zich mogelijk ziek voelen wat het welzijn negatief beïnvloed. Het verstrekken van voer op het strooisel lijkt geen grote verbeteringen van het gedrag met zich mee te brengen. Daarentegen lijkt het vaker voeren (bijv. tweemaal) per dag een kansrijke oplossing door de (kleine) verbeteringen van het gedrag in combinatie met bijvoorbeeld de uniformiteit. 


\section{Honger}

\subsection{Definitie van honger}

Als direct gevolg van voercontrole bij vleeskuikenouderdieren wordt vaak gesproken over de honger die de dieren ervaren. Uit een inventarisatie van de beschikbare literatuur blijkt dat het term honger steeds vaker genoemd wordt in papers met betrekking tot ouderdieren. Tussen 1981 en 2000 werd honger in 8 papers genoemd terwijl dat tussen 2001 en 202045 maal was. Van Dale definieert honger kort en krachtig als: 'de behoefte aan voedsel'. Het ethologische woordenboek van Oxford (www.oxfordreference.com) geeft de volgende definitie: 'A lack of sufficient food to meet a person's necessary requirements for sustained physiological health. Chronic hunger can lead to famine and starvation.' In het Nederlands: 'Een gebrek aan voldoende voedsel om te voldoen aan de noodzakelijke eisen van een persoon voor een langdurige fysiologische gezondheid. Chronische honger kan leiden tot hongersnood en verhongering.'

Honger (of het omgekeerde, verzadiging) bij vleeskuikenouderdieren is meestal niet goed gedefinieerd in de literatuur (Day et al. 1997). In een artikel van D'Eath et al. (2009) wordt honger gedefinieerd als een negatieve subjectieve toestand die wordt ervaren door een dier dat chronisch ondervoed is. Enkele kanttekeningen en motiveringen voor deze definitie zijn als volgt:

1. $\mathrm{Zij}$ benadrukken het belang van de langere termijn omdat chronische voercontrole een veel grotere invloed heeft op de voedingsmotivatie dan acuut voedselgebrek (Savory et al., 1993; Ferguson en Paule, 1995, 1997; Bokkers et al., 2004). Bijvoorbeeld, vleeskuikenouderdieren die ongeveer 30\% van ad libitum werden gevoerd, waren meer dan driemaal zo gemotiveerd om een taak uit te voeren dan dieren die ad libitum voer kregen en daarna een 72 uur durende periode van vasten (Savory et al., 1993). Deze definitie vermijdt ook verwarring met termen die verband houden met de regulering van de eetlust op korte termijn. Dieren eten totdat ze 'verzadigd' zijn (vervolgens eindigt de maaltijd) en vasten tot de 'verzadiging' afneemt in 'honger' wat resulteert in de volgende maaltijd (o.a. de Graaf et al., 2004).

2. Dierlijke subjectieve statussen zijn een cruciaal onderdeel van dierenwelzijn (Dawkins, 1990; Duncan, 1993; Fraser en Duncan, 1998). Dit is minstens zo belangrijk als natuurlijkheid van gedrag, functionaliteit en gezondheidsoverwegingen (Fraser et al., 1997). Hoewel een subjectieve status van dieren niet rechtstreeks kan worden waargenomen, moet de keuze van indirecte hongerindicatoren idealiter worden beoordeeld door hun waarschijnlijke relatie met de subjectieve perceptie van honger. 3. De verwijzing naar ondervoeding is enigszins algemeen, wat de invloed van specifieke nutriënten zouden kunnen zijn, terzijde schuift (bijv. Kyriazakis, 1994). Bij zeugen en vleeskuikenouderdieren zijn voeders vooral bedoeld om de energie-opname te controleren. Het concept van ondervoeding houdt in dat de opname van het dier niet voldoet aan de 'gewenste' opname.

\subsection{Meten van honger}

Het direct meten van honger aan dieren (en dus ook vleeskuikenouderdieren) is erg lastig en is daarom altijd een afgeleide van geaccepteerde indirecte indicatoren van honger. Dit zijn dan meestal fysiologische parameters in combinatie met observaties aan specifieke gedragsuitingen. Bij vleeskuikenouderdieren met name stereotiep pikgedrag naar objecten of staarten. De vraag hoe het dierenwelzijn in het algemeen kan worden gemeten, is eerder onderzocht en beschreven (bijv. Broom en Johnson, 1993; Mason en Mendl, 1993; Dantzer, 2002; Paul et al., 2005; Botreau et al., 2007), en deze discussie is ook relevant voor de beoordeling van honger. Mason en Mendl (1993) beschreven bijvoorbeeld hoe welzijnsmaatregelen doorgaans op twee manieren worden gevalideerd: (1) door reacties te meten op een situatie of stimulus waarvan de onderzoeker denkt dat deze aversief is (bijv. onvermijdelijke elektrische schokken, isolatie van een sociale groep).

(2) naar analogie met de reacties van mensen die negatieve emotionele toestanden rapporteren.

De eerste wordt vaak toegepast op de mate van honger te meten, waarbij verschillende niveaus van kwantitatieve voercontrole worden gebruikt. De tweede is ook relevant, waarbij sommige onderzoekers verwijzen naar de humane literatuur ter ondersteuning van hun gekozen maatregelen 
(bijv. de Leeuw, 2004). In de literatuur over voersystemen voor zeugen en vleeskuikenouderdieren hebben wetenschappers om honger te meten, gebruik gemaakt van indicatoren die in het algemeen worden gebruikt bij de beoordeling van dierenwelzijn (bijv. HPA-as metingen, stereotypie, mate van motivatie zoals operante conditionering) en parameters die meer specifiek verband houden met voeding (bijv. glucose/NEFA (=niet-veresterde vetzuren) verhouding, insulinegehalte, voedingssnelheid, compenserende voeropname). Om hongerindicatoren te valideren, is het gebruikelijk om de indicator eerst te testen met verschillende niveaus van kwantitatieve voercontrole, en vervolgens deze methode toe te passen om alternatieve diëten te vergelijken met kwantitatieve voercontrole. Soms worden beide benaderingen gecombineerd in één experiment (bijv. Lawrence et al., 1989; Savory et al., 1996; Bergeron et al., 2000; Savory en Lariviere, 2000). Dit lijkt op het eerste gezicht verstandig, maar kan in de praktijk problematisch zijn. Om bijvoorbeeld verschillende niveaus van honger te beoordelen, pasten de Jong et al. (2003) verschillende niveaus van kwantitatieve voercontrole bij opfok ouderdieren toe. Indicatoren die lineair varieerden met het niveau van voercontrole, werden geïdentificeerd als indicatoren voor honger. Bijvoorbeeld, met toenemende kwantitatieve voercontrole, daalden de plasmaspiegels van NEFA, vermoedelijk als gevolg van verminderde adipositas (vetvorming), terwijl de glucosespiegels hetzelfde bleven, wat leidde tot een verhoogde glucose/NEFA-verhouding. In een later onderzoek waarin drie alternatieve voeders werden vergeleken met kwantitatieve voercontrole bij opfok vleeskuikenouderdieren, was de glucose/NEFA die op hetzelfde moment van de dag in elke behandeling werd bemonsterd, lager bij kwantitatieve voercontrole (de Jong et al., 2005b), wat lijkt te suggereren dat deze dieren minder honger hadden dan die op de alternatieve voeders. De Jong et al. (2005b) concludeerden in plaats daarvan dat het ontbreken van een 24-uurs profiel het moeilijk maakt om kwantitatieve voercontrole te vergelijken met alternatieve voeders, vermoedelijk omdat de hogere glucosepiek na de maaltijd die onder kwantitatieve voercontrole wordt gezien, het resultaat mogelijk heeft beïnvloed. Deze twee studies illustreren de moeilijkheid met dergelijke metingen en illustreren in het algemeen de moeilijkheid om metingen met verschillende niveaus van kwantitatieve voercontrole te valideren en toe te passen op de kwantitatieve voercontrole versus vergelijking van alternatieve voeders. Een hiaat in dergelijke onderzoeken is dat uiterlijke indicatoren die variëren met het niveau van voercontrole mogelijk alleen de staat van voeding meten, wat niet noodzakelijkerwijs overeenkomt met de negatieve emotionele toestand van het dier. Als alternatief is betoogd dat indicatoren die pas beginnen te veranderen nadat een bepaald drempelniveau is bereikt, eerder op honger kunnen duiden (Hocking et al., 1996). Een andere moeilijkheid heeft betrekking op de manier waarop verschillende maatregelen moeten worden geïntegreerd. In dierenwelzijn studies is het heel gebruikelijk om een reeks maatregelen te gebruiken en ze samen te interpreteren, bijvoorbeeld gedrag om de interpretatie van fysiologie te ondersteunen (Broom en Johnson, 1993; Mason en Mendl, 1993). Onderzoek naar effecten van voercontrole leidt echter vaak tot verschillende maatregelen die op verschillende conclusies wijzen. De Jong et al. (2005b) ontdekte dat alternatieve voeders (in vergelijking met kwantitatieve voercontrole) leidden tot minder objectpikken, meer eten en meer zitten, wat duidde op verminderde honger. De glucose/NEFAratio was echter hoger (zoals al besproken) en de stress-indicator heterofiel/lymfocyt $(H / L)$-ratio was ook hoger. De auteurs verklaarden de hogere $\mathrm{H} / \mathrm{L}$-verhouding uit door de verhoogde stress en langdurige honger als gevolg van vertraagde verzadiging, omdat kippen veel langer nodig hadden om hun voedsel op te eten. In het licht van deze ogenschijnlijk tegenstrijdige resultaten, concludeerden ze in het algemeen dat 'een voeder met een lage dichtheid een klein positief effect zou kunnen hebben op het welzijn van vleeskuikenouderdieren'.

\subsection{Samenvatting honger}

Onderzoek naar de effecten van voercontrole op honger zijn de laatste 40 jaar flink toegenomen. Het meten van honger bij dieren is niet mogelijk via een directe methode en de mate van honger wordt dan ook meestal via een combinatie van (indirecte) observaties vastgesteld. Bij vleeskuikenouderdieren wordt honger gemeten door een combinatie van vooral stereotiep pikgedrag en fysiologische parameters. Ook dit is niet eenvoudig en de verschillende experimenten geven regelmatig tegenstrijdige conclusies. 


\section{Voercontrole bij huis- en laboratorium dieren}

\subsection{Prevalentie obesitas huisdieren}

Voor honden wordt de prevalentie van overgewicht en obesitas geschat tussen 19,7 tot 59,3\% (McGreevy et al., 2005; Lund et al., 2006; Hill, 2009; Courcier et al., 2010; Corbee, 2013; Mao et al., 2013) en voor katten op 11,5 tot 52,0\% (Burkholder en Toll, 2000; Lund et al., 2005; German, 2006; Hill, 2009; Courcier et al., 2010b, 2012; Cave et al., 2012; Corbee, 2014). In een veterinaire praktijkpopulatie met huisdieren in de VS werden de dieren over een periode van 5 jaar (van 2007 tot 2011)van gevolgd. Men vond dat het overgewicht en obesitas met $37 \%$ bij de honden en met $90 \%$ bij de katten toenam (Banfield, 2012).

\subsection{Oorzaken en gevolgen overgewicht huisdieren}

Dieren die worden blootgesteld aan een grote verscheidenheid aan ad libitum verstrekte voedingsmiddelen van hoge kwaliteit slaan overtollige energie op als vetweefsel, waardoor ze overgewicht of obesitas ontwikkelen (West en York, 1998; Lieberman, 2006). Overmatige energiedepositie is een reëel en potentieel probleem bij dieren in gevangenschap, waaronder gezelschapsdieren (Buffington, 1994; Hawn, 2005; German, 2006), dierentuindieren (Schwitzer en Kaumanns, 2001) en proefdieren (Home Office, 1989, 2003). Het kan leiden tot gezondheidsproblemen zoals diabetes mellitus, cardiorespiratoire aandoeningen waaronder hartfalen, urinewegaandoeningen, voortplantingsstoornissen, bewegingsproblemen (kreupelheid), tumoren en verhoogde uitval (Fan et al., 2003; Hawn, 2005; German, 2006). Overgewicht bij dieren kan ook resulteren in hittestress (Savory et al., 1993b; Kubíková et al., 2001).

De oorzaken van obesitas zijn multifactorieel, waarbij de genetica en omgeving een grote rol spelen. Zwaarlijvigheid is uiteindelijk het resultaat van een onevenwichtige energiebalans: te veel opgenomen calorieën vaak in combinatie met te weinig verbruikte calorieën (Zoran, 2010). Bij specifieke honden en katten rassen is aanleg een erkende factor voor het ontwikkelen van obesitas (Edney en Smith, 1986; Gosslink et al., 2007) naast andere factoren, zoals leeftijd, geslacht, castratie en hormonale invloeden die een belangrijke rol spelen bij de ontwikkeling van obesitas. Obesitas komt bijvoorbeeld meer voor bij jonge teven, terwijl bij het ouder worden circa $40 \%$ van zowel de teven en reuen obese zijn (o.a. McGreevy et al., 2005).

Voeding speelt een rol bij overgewicht en obesitas van huisdieren. Vetrijke voeders worden in verband gebracht met overgewicht of obesitas bij honden (Laflamme, 2006). De bron van voedsel (commercieel bereid versus zelfgemaakt) was in één onderzoek geen significante factor voor obesitas bij honden (Kienzle et al., 1998), maar een niet-commerciële voedingsbron was benoemd als een risicofactor in een ander onderzoek (Mao et al., 2013). De prijs van voer voor huisdieren wordt in verband gebracht met obesitas; eigenaren van zwaarlijvige honden verstrekken goedkoper voedsel (Kienzle et al., 1998). Obesitas wordt ook in verband gebracht met het aantal humane maaltijden en snacks dat aan de dieren wordt gevoerd. Zo worden keuken- of tafelresten, vers vlees en commerciële snacks in verband gebracht met obesitas bij honden (Kienzle et al., 1998; Bland et al., 2009; Sallander et al., 2010) evenals het ongelimiteerd verstrekken van voer bij katten (Courcier et al., 2010b).

Obesitas heeft een versterkende, negatieve werking op de gezondheid van huisdieren. Er zijn relaties op populatieniveau aangetoond tussen obesitas en comorbide (twee of meer stoornissen of aandoeningen). Ziekten die gelijktijdig met overgewicht of obesitas worden aangetroffen, omvatten artritis, endocriene disfunctie (bijv. hypothyreoïdie, hyperadrenocorticisme), kruisbandbreuk, urinewegaandoeningen, mondziekte, diabetes mellitus, pancreatitis en neoplasie (Hess et al., 1999; Lund et al., 2005; Lund et al., 2006; Laflamme, 2006; Marshall et al., 2009). Het risico op inactiviteit is ook verhoogd bij honden met overgewicht of obesitas (German, 2006). 
Sommige van deze associaties zijn waarschijnlijk causaal (bijv. hypothyreoïdie bij honden) en sommige zijn het gevolg van overmatige lichaamsconditie (bijv. pancreatitis bij honden en diabetes mellitus bij katten). De levensduur voor mensen met een gezond lichaamsgewicht is groter dan voor mensen met obesitas (Kolonin et al., 2004; Houston et al., 2009). Er zijn aanwijzingen dat dit ook geldt voor honden (Kealy et al., 2000).

\subsection{Voercontrole huisdieren}

Voor verschillende in gevangenschap levende dieren wordt de voedsel hoeveelheid gecontroleerd om ervoor te zorgen dat hun lichaamsgewicht een goede gezondheid en reproductie efficiëntie garandeert en om obesitas te voorkomen ( $D^{\prime}$ Eath et al., 2009). Meestal wordt dit bereikt door de hoeveelheid aangeboden voedsel te controleren (kwantitatieve beperking), maar dit kan leiden tot honger, wat blijkt uit een verhoogde motivatie voor voedsel en meer activiteit, met name foerageergedrag (Epling en Pierce, 1988; Lawrence et al., 1993; Vitousek et al., 2004). Zodra voedsel is geconsumeerd, wordt foerageeractiviteit omgeleid naar niet-voedingssubstraten en kan het stereotiep van aard worden (Rushen, 1985; Lawrence en Terlouw, 1993).

Om problemen met overgewicht bij honden te voorkomen, wordt veel aandacht besteed aan het controleren van de voedselhoeveelheid (Kealy et al., 2002; Hill et al., 2005; Lawler et al., 2007, 2008). Deze aanpassingen zijn nodig omdat de meeste gedomesticeerde honden de voedselinname niet zelf reguleren naar de energiebehoeften en dus gevoelig zijn om obese te worden (Lawler et al., 2008). Bij de meeste studies met honden kregen de dieren 75\% voer t.o.v. de ad libitum gevoerde dieren. Bijvoorbeeld in het onderzoek van Lawler et al. (2008) werden 48 Labrador retrievers gevolgd tot hun overlijden (14,5 jaar de laatste). De ene groep kreeg ad libitum voer en de andere groep kreeg $75 \%$ van deze hoeveelheid (25\% voercontrole) en de gemiddelde leeftijd van overlijden was 11,2 (ad libitum) en 13,0 jaar (gecontroleerd gevoerd). De honden die gecontroleerd gevoerd werden leefden 1,8 jaar langer doordat ze pas op latere leeftijd problemen kregen met name osteoartritis. Langdurige voercontrole had verder een positieve invloed op de sterkte van het skelet.

Gedurende het laatste decennium wordt veel onderzoek gedaan naar de effecten van voeders om het overgewicht van huisdieren te verlagen (o.a. Bissot et al., 2009; Flanagan et al., 2017, 2018; Keller et al., 2020). In het experiment van Keller et al. (2020) werden 67 honden en 17 katten met overgewicht gevolgd terwijl ze gedurende 8 weken gevoerd werden met ongeveer $80 \%$ van de onderhoudsenergiebehoefte voor een ideaal lichaamsgewicht. Bij $84 \%$ van de honden en $100 \%$ van de katten werd een gewichtsverlies van respectievelijk $4,7 \%$ en $6,4 \%$ gevonden zonder nadelige neveneffecten. Het gewichtsverlies was vergelijkbaar met eerdere min of meer dezelfde studies (Bissot et al., 2009; Flanagan et al., 2017, 2018). In andere studies met een lagere energieopname (55-60\% t.o.v. ad libitum) werden logischerwijs een grotere gewichtsvermindering gevonden (German et al., 2015; Flanagan et al., 2017).

\subsection{Voercontrole laboratorium dieren}

Laboratorium dieren (ratten, muizen, hamster, guinea pig, etc.) zijn dieren die gebruikt worden voor het doen van experimenten die vaak als model dienen voor mensen (Savenije et al., 2010). Voor het welzijn van laboratorium dieren is het essentieel dat de dieren voldoende voedsel met essentiële voedingsstoffen krijgen (Beynen en Coates, 2001; Ritskes-Hoitinga, 2004, Savenije et al., 2010). Door een ideale omgeving te creëren voor de laboratorium dieren zijn de uitkomsten van de experimenten valide zonder dat ze beïnvloed worden door stress of gezondheidsproblemen (Savenije et al., 2010). Fysieke en mentale processen zijn afhankelijk van, en worden beïnvloed door wat wordt opgenomen en wanneer en hoe het voedsel wordt opgenomen (Ritskes-Hoitinga en Chwalibog, 2003). Opname van voedsel is essentieel voor homeostase, een gereguleerde staat van intern evenwicht (Strubbe, 2003; Ritskes-Hoitinga en Strubbe, 2004), hoewel het altijd leidt tot enige homeostatische verstoring, bijvoorbeeld door het thermogene effect. Aangezien veel lichaamsfuncties van nature biologische ritmes vertonen, kunnen schommelingen als gevolg van voedselopname leiden tot een goed dierenwelzijn, zolang het dier in staat is terug te keren naar de homeostatische toestand. 
Het introduceren van soort specifieke fluctuaties in het voerproces in het laboratorium kan daarom een positieve bijdrage leveren aan het welzijn van proefdieren. Knaagdieren worden in de meeste experimenten ad libitum gevoerd (Savenije et al., 2010). Ad libitum voeren van knaagdieren kan vanuit praktisch oogpunt aantrekkelijk zijn omdat er geen speciaal voersysteem of speciale zorg vereist is. Echter, op basis van resultaten van toxicologische studies op lange termijn is het de vraag of dit een gedegen wetenschappelijke of welzijnsbenadering is. Ad libitum voeding leidt op lange termijn namelijk tot negatieve gezondheidseffecten in vergelijking met beperkte voeding ( $75 \%$ van de ad libitum opname) (Keenan et al., 1994, 1996, 1999; Masoro, 2005). Deze omvatten een kortere overlevingsduur, meer gevallen van obesitas, degeneratieve nier- en hartaandoeningen en kanker op jongere leeftijd (Hart et al. 1995). Een gecontroleerde voedselopname kan andere positieve effecten hebben op de gezondheid. Zo is de relatieve afname van het lichaamsgewicht 48 uur na de operatie (jugulaire canulatie) kleiner bij dieren die beperkt zijn in voedsel vergeleken met ad libitum gevoerde ratten (zowel op de leeftijd van 3-4 en 17-18 maanden) (Hart et al., 1995). Er wordt aangegeven dat dieren 'robuuster' worden als de voedselinname wordt gecontroleerd, dat wil zeggen dat ze beter kunnen omgaan met experimentele stressoren en gerelateerde procedures (Keenan et al., 1999). Het verdunnen van het voer, bijvoorbeeld door een hoger vezelgehalte op te nemen onder ad libitumomstandigheden, geeft niet dezelfde positieve gezondheidseffecten in vergelijking met voedselcontrole (Hart et al., 1995).

\subsection{Samenvatting voercontrole huis- en laboratoriumdieren}

De prevalentie van overgewicht en obesitas bij honden en katten wordt geschat op respectievelijk gemiddeld $40 \%$ en $32 \%$ terwijl dit lijkt toe te nemen. De oorzaken van overgewicht en obesitas bij huisdieren zijn multifactorieel, maar de opname van hoog kwalitatief voedsel die opgeslagen wordt als vetweefsel is de belangrijkste. Daarnaast spelen zaken mee als zoals activiteit, leeftijd, geslacht, castratie en hormonale invloeden. Overgewicht kan leiden tot gezondheidsproblemen zoals diabetes mellitus, hartfalen, urinewegaandoeningen, voortplantingsstoornissen, bewegingsproblemen, tumoren en verhoogde mortaliteit.

Om problemen met overgewicht bij honden te voorkomen, wordt veel aandacht besteed aan het controleren van de voedselhoeveelheid. In experimenten wordt vaak $75 \%$ van de ad libitum hoeveelheid voer verstrekt wat een positieve invloed geeft op de gezondheid van de dieren. Daardoor leven de dieren langer, krijgen ze pas op latere leeftijd problemen met de gezondheid en hebben ze een sterker skelet.

Overgewicht speelt ook een belangrijke rol bij laboratoriumdieren omdat ad libitum voeding leidt tot negatieve effecten op gezondheid, waardoor dit nadelig is voor het welzijn van de dieren en negatieve neveneffecten kan geven op de uitkomsten van experimenten. Om overgewicht te voorkomen krijgen huis- en laboratoriumdieren meestal een gecontroleerde voergift van 75 tot $80 \%$ t.o.v. de ad libitum voergift. 


\section{Conclusies en aanbevelingen}

\section{Conclusies}

Uit het literatuuronderzoek kunnen de volgende conclusies getrokken worden:

- De oorzaak van voercontrole bij vleeskuikenouderdieren komt door het verschil tussen de streefgewichten van vleeskuikens en vleeskuikenouderdieren op dezelfde leeftijd.

- Experimenten en berekeningen om een betrouwbaar niveau van voercontrole te bepalen moeten worden uitgevoerd bij vergelijkbare lichaamsgewichten en energieopname per dag.

- Uit berekeningen blijkt dat de gemiddelde energiecontrole bij vleeskuikenouderdieren tijdens de opfok- en legperiode respectievelijk $47 \%$ en $35 \%$ is. Doordat ouderdieren niet exact hetzelfde groeipotentieel hebben, en door het heterosis effect bij de nakomelingen, is dit mogelijk een overschatting en zal de werkelijke energiecontrole wat lager zijn (schatting is $10 \%$ lager): respectievelijk $42 \%$ en $31 \%$. Dit is beduidend lager de 66 tot $75 \%$ en 20 tot $55 \%$ die in de literatuur wordt gehanteerd voor de opfok-en legperiode.

- Via factoriele berekeningen t.o.v. de energiebehoefte wordt de energiecontrole tijdens de opfok- en legperiode geschat op respectievelijk $12 \%$ en $3 \%$.

- Plasma corticosteron concentratie lijkt niet geschikt als welzijnsindicator, terwijl hematologische metingen (verhouding heterofielen en basofielen t.o.v. lymfocyten) wel geschikt lijken.

- Stereotiep pikgedrag naar objecten en staartlikken lijken betrouwbare welzijnsindicatoren.

- Stereotiep pikken naar een ogenschijnlijk leeg voersysteem is mogelijk geen betrouwbare welzijnsindicator. Doordat de dieren op bijvoorbeeld de lege voerpan of aanvoervijzel pikken komt er mogelijk wat restvoer vrij dat werkt als een beloning voor het pikgedrag. Aan de andere kant, kan het wel een indicatie zijn van een sterke voeropname motivatie om zo veel mogelijk te pikken naar alle kleine voerresten.

- Het pikken naar water en lopen voor het voeren zijn geen geschikte welzijnsindicatoren. Alhoewel het staartlikken ook te maken kan hebben met het opnemen van vet uit de stuitklier.

- Het stereotiep pikgedrag is een indicator van verminderd welzijn terwijl de voeropname motivatie van de dieren erg hoog is. Daarnaast is te beargumenteren dat het stereotiep pikgedrag mede ontstaat door een mismatch in tijdsbesteding doordat de dieren het voer te snel opnemen. Een combinatie van maatregelen om de voeropnametijd maximaal te verlengen om de gevolgen van voercontrole te verminderen, lijkt het meeste effect te genereren.

- Ad libitum voer verstrekken resulteert in nadelige effecten op gezondheid en reproductie.

- Het inzetten van ouderdieren van trager groeiende rassen is geen goed alternatief voor voercontrole, doordat de brede duurzaamheid (People, Planet, Profit) bij de vleeskuikens hiermee in het gedrang komt.

- Het toevoegen van eetlustonderdrukkers zoals calciumpropionaat lijkt geen goede methode omdat de dieren zich mogelijk ziek voelen.

- Het vaststellen van de mate van honger bij vleeskuikenouderdieren kan alleen via een combinatie van indirecte observaties die niet altijd eenduidig zijn.

- De prevalentie van overgewicht en obesitas bij honden en katten wordt geschat op respectievelijk $40 \%$ en $32 \%$, en lijkt toe te nemen.

- Overgewicht bij laboratoriumdieren leidt tot negatieve effecten op gezondheid, welzijn en de uitkomsten van experimenten.

- Om overgewicht te voorkomen krijgen huis- en laboratoriumdieren meestal een gecontroleerde voergift van 75 tot $80 \%$ t.o.v. de ad libitum voergift verstrekt (20 tot $25 \%$ voercontrole).

\section{Aanbevelingen}

- Verschillende combinaties van maatregelen onderzoeken om de gevolgen van voercontrole te verminderen, lijkt het meeste effect te genereren. Daardoor wordt gedacht aan meerdere keren per dag voeren, verschillende methoden van voer verstrekken en verdund voer in combinatie met innovatieve oplossingen.

- Onderzoek verrichten naar het effect van gecontroleerd of ongecontroleerd water verstrekken tijdens de opfok- en legperiode op gedrag en fysiologische parameters.

- Experimenten uitvoeren om meer inzicht te krijgen in fysiologische indicatoren voor honger. Verder is meer onderzoek nodig naar betere testen om voeropnamemotivatie te meten. 


\section{Literatuur}

Agrimatie. 2020.

https://www.agrimatie.nl/PublicatiePage.aspx?subpubID=2525\&themaID =3577\&indicatorID = 3591 \&sectorID $=2249$

Albers, G.A.A. 1998. Future trends in poultry breeding. In: Proceedings of the 10th European Poultry Conference. WPSA, Israel Branch, Jerusalem, pp. 16-20.

Appleby, M.C., Hughes, B.O., Hogarth, G.S. 1989. Behaviour of laying hens in a deep litter house. Br. Poult. Sci. 30:545-553.

Appleby, M.C. 2004. What causes crowding? Effects of space, facilities and group size on behaviour, with particular reference to furnished cages for hens. Anim. Welf. 13:13-320.

Arrazola, A. 2018. The effect of alternative feeding strategies for broiler breeder pullets throughout the production cycle. PhD Diss. The University of Guelph, Guelph, Ontario, Canada.

Arrazola, A., Mosco, E., Widowski, T.M., Guerin, M.T., Kiarie, E.G., Torrey, S. 2019. The effect of alternative feeding strategies for broiler breeder pullets: 1 . Welfare and performance during rearing. Poult. Sci. 3370-3390.

Arrazola, A., Mosco, E., Widowski, T.M., Guerin, M.T., Kiarie, E.G. 2020. The effect of alternative feeding strategies during rearing on the behaviour of broiler breeder pullets. Appl. Anim. Behav. Sci. 224:1-8.

Aviagen-EPI, 2017. Managementgids Ross 308 ouderdieren. Roermond, Nederland.

Aviagen. 2016a. European Parent Stock. Ross 308 Parent Stock: Performance Objectives. Aviagen, Ltd., Huntsville, Alabama, USA.

Aviagen. 2016b. Parent Stock. Ross 308 Parent Stock: Nutrition specifications. Aviagen, Ltd., Huntsville, Alabama, USA.

Aviagen. 2019a. Broiler. Ross 308/Ross 308 FF Broiler: Performance objectives. Aviagen, Ltd., Huntsville, Alabama, USA.

Aviagen. 2019b. Broiler. Ross Broiler: Nutrition specifications (all plan protein-based feeds). Aviagen, Ltd., Huntsville, Alabama, USA.

Banfield. 2012. State of Pet Health Report. https://www.banfield.com/Banfield/media/PDF/Downloads/soph/ Banfield-State-of-Pet-HealthReport_2012.pdf.

Bennett, C., Leeson, S. 1989. Research note: Growth of broiler breeder pullets with skip-a-day versus daily feeding. Poult. Sci. 68:836-838.

Bennett, C.D., Leeson, S. 1990. Body composition of the broiler-breeder pullet. Poult. Sci. 69:715720.

Bergeron, R., Bolduc, J., Ramonet, Y., Meunier-Salaun, M.C., Robert, S. 2000. Feeding motivation and stereotypies in pregnant sows fed increasing levels of fibre and/or food. Appl. Anim. Behav. Sci. 70:27-40.

Beynen, A.C., Coates, M.E. 2001. Nutrition and experimental results. In: Principles of Laboratory Animal Science. Eds van Zutphen, L.F.M., Baumans, V., Beynen, A.C., pp. 111-128. Elsevier Scientific Publishers, Amsterdam, the Netherlands.

Bissot, T., Servet, E., Vidal, S., Deboise, M., Sergeraert, R., Egron, E., Hugonnard, M., Heath, S.E., Biourge, V., German, A.J., 2009. Novel dietary strategies can improve the outcome of weight loss programmes in obese client-owned cats. J. Fel. Med. Surg. 12:104-112.

Bland, I.M., Guthrie-Jones, A., Taylor, R.D., Hill, J. 2009. Dog obesity: owner attitudes and behaviour. Prev. Vet. Med. 92:333-340.

Blas, J. 2015. Stress in birds. Pages 769-810 in Sturkie's Avian Physiology (Sixth Edition) Elsevier.

Bokkers, E.A.M., Koene, P., Rodenburg, T.B., Zimmerman, P.H., Spruijt, B.M. 2004. Working for food under conditions of varying motivation in broilers. Anim. Behav. 68:105-113.

Botreau, R., Bonde, M., Butterworth, A., Perny, P., Bracke, M.B.M., Capdeville, J., Veissier, I. 2007. Aggregation of measures to produce an overall assessment of animal welfare. Part 1: a review of existing methods. Anim. 1:1179-1187.

Brake, J. 1987. Influence of presence of perches during rearing on incidence of floor laying in broiler breeders. Poult. Sci. 66:1587-1589.

Broom, D.M., Johnson, K.G. 1993. Stress and Animal Welfare. Chapman \& Hall, London, UK. 
Bruggeman, V., Onagbesan, O., Ragot, O., Metayer, S., Cassy, S., Favreau, F., Jego, Y., Trevidy, J., Tona, K., Williams, J., Decuypere, E., Picard, M. 2005. Feed allowance-genotype interactions in broiler breeder hens. Poult. Sci. 84:298-306.

Buckley, L.A., McMillan, L.M., Sandilands, V., Tolkamp, B.J., Hocking, P.M., D’Eath, R.B. 2011. hungry to learn? Hungry broiler breeders fail to learn a Y-maze food quantity discrimination task. Anim. Welf. 20,469-481.

Buffington, C.A.T. 1994. Management of obesity: the clinical nutritionist's experience. Int. J. Obesity 18:S29-S35.

Burkholder, W.J., Toll, P.W. 2000. Obesity. In: Small Animal Clinical Nutrition, 4th Edit., Hand, M.S., Thatcher, C.D., Reimillard, R.L., Roudebush, P., Morrism, M.L. et al., Eds., Mark Morris Institute, Topeka, pp. 401-430.

Burton, T., Metcalfe, N.B. 2014. Can environmental conditions experienced in early life influence future generations? Proc. R. Soc. 281:03-11.

Cave, N.J., Allan, F.J., Schokkenbroek, S.L., Metekohy, C.A., Pfeiffer, D.U. 2012. A cross-sectional study to compare changes in the prevalence and risk factors for feline obesity between 1993 and 2007 in New Zealand. Prev. Vet. Med. 107:121:133.

CBS, 2020. https://opendata.cbs.nl/\#/CBS/nl/dataset/81302ned/table?ts=1592900524357

Chen, S., McMurtry, J., Walzem, R. 2006. Overfeeding-induced ovarian dysfunction in broiler breeder hens is associated with lipotoxicity. Poult. Sci. 85:70-81.

Cho. S. 2019. Nutrient specific appetites and feather pecking behaviour in laying hens. PhD Diss. The University of Queensland, Queensland, Australia.

Cobb, 2016. Managementguide Cobb 500. Siloam Springs, Arkansas, USA.

Corbee, R.J. 2014. Obesity in show cats. J. Anim. Physiol. Anim. Nutr. 98:1075-1080.

Courcier, E.A., O'Higgins, R., Mellor, D.J., Yam, P.S. 2010. Prevalence and risk factors for feline obesity in a first opinion practice in Glasgow, Scotland. J. Feline Med. Surg. 12:746-753.

Courcier, E.A., Mellor, D.J., Pendlebury, E., Evans, C., Yam, P.S. 2012. An investigation into the epidemiology of feline obesity in Great Britain: results of a cross-sectional study of 47 companion animal practises. Vet. Rec. 171:560.

Dantzer, R. 2002. Can farm animal welfare be understood without taking into account the issues of emotion and cognition? J. Anim. Sci. 80:E1-E9.

da Silva-Filardi, R., Basaglia, R., Rabello, C.B.V., Longo, F.A., Sakomura, N.K., Junqueira, O.M. 2004. Avaliação das equações de predição das exigências de proteína para matrizes pesadas na fase de crescimento. R. Bras. Zootec. 33:901-910.

Dawkins, M.S. 1990. From an animal's point of view: motivation, fitness and animal welfare. Behav. Brain Sci. 13:1-61.

Dawkins, M.S., Layton, R. 2012. Breeding for better welfare: genetic goals for broiler chickens and their parents. Anim. Welf. 21:147-155.

Day, J.E.L., Kyriazakis, I., Rogers, P.J. 1997. Feeding motivation in animals and humans: a comparative review of its measurement and uses. Nutr. Abstr. Rev. 67:69-79.

de Beer, M. 2009. Current approaches to feeding broiler breeders. Pages 104-114 in Proc. 17th Eur. Symp. Poult. Nutr., Edinburgh, Scotland. World's Poult. Sci. Assoc., Attleborough, United Kingdom.

de Beer, M., Coon, C.N. 2007. The effect of different feed restriction programs on reproductive performance, efficiency, frame size, and uniformity in broiler breeder hens. Poult. Sci. 86:19271939.

de Beer, M., Coon, C. 2009. The effect of feed restriction programs and growth curves on reproductive performance, in vitro lipogenesis and heterophil to lymphocyte ratios in broiler breeder hens. Intern. J. Poult. Sci. 8:373-388.

Decuypere, E., Hocking, P.M., Tona, K., Onagbesan, O., Bruggeman, V., Jones, E.K.M., Cassy, S., Rideau, N., Metayer, S., Jego, Y., Putterflam, J., Tesseraud, S., Collin, A., Duclos, M. Trevidy, J.J., Williams, J. 2006. Broiler breeder paradox: a project report. World's Poult. Sci. J. 62:443-53.

Decuypere, E., Bruggeman, V., Everaert, N. Yue Li, Boonen, R., de Tavernier, J., Janssens, S., Buys, N. 2010. The Broiler Breeder Paradox: ethical, genetic and physiological perspectives, and suggestions for solutions. Br. Poult. Sci. 51:569-579.

D'Eath, R.B., Tolkamp, B.J., Kyriazakis, I., Lawrence, A.B. 2009. 'Freedom from hunger' and preventing obesity: the animal welfare implications of reducing foot quantity or food quality. Anim. Behav. 77:275-288. 
de Graaf, C., Blom, W.A.M., Smeets, P.A.M., Stafleu, A., Hendriks, H.F.J. 2004. Biomarkers of satiation and satiety. Am. J. Clin. Nutr. 79:946-961.

de Jong, I.C., van Voorst, A.S., Ehlhardt, D.A., Blokhuis, H.J. 2002. Effects of restricted feeding on physiological stress parameters in growing broiler breeders. Br. Poult. Sci. 43:157-168.

de Jong, I.C., van Voorst, A.S., Blokhuis, H.J. 2003. Parameters for quantification of hunger in broiler breeders. Physiol. Behav. 78:773-783.

de Jong, I.C., Fillerup, M., Blokhuis, H.J. 2005a. Effect of scattered feeding and feeding twice a day during rearing on parameters of hunger and frustration in broiler breeders. Appl. Anim. Behav. Sci. 92:61-76.

de Jong, I.C., Enting, H., van Voorst, S., Blokhuis, H.J. 2005b. Do low-density diets improve broiler breeder welfare during rearing and laying? Poult. Sci. 84:194-203.

de Jong, I.C., Jones, B. 2006. Feed restriction and welfare in domestic birds. Pages 120-135 in Feeding in domestic vertebrates. From structure to behavior. V. Bels ed. CABI Publishing, Wallingford, UK.

de Jong, I.C., Guémené, D. 2011. Major welfare issues in broiler breeders. World's Poult. Sci. J. 67:73-81.

de Jong, I.C., Reuvekamp, B.F.J., Gunnink, H. 2013. Can substrate in early rearing prevent feather pecking in adult laying hens? Anim. Welf. 22:305-314.

de Jong, I.C., van Emous, R.A. 2017. Broiler breeding flocks: management and animal welfare. In: Achieving sustainable production of poultry meat (T Applegate, eds.). Burleigh Dodds Sci. Publ. Lim, UK. pp: 211-230.

de Leeuw, J.A. 2004. Stimulation of behavioural and nutritional satiety in sows. Ph.D. thesis, Wageningen University.

de los Mozos, J., García-Ruiz, A.I., den Hartog, L.A., Villamide, M.J. 2017. Growth curve and diet density affect eating motivation, behavior, and body composition of broiler breeders during rearing. Poult. Sci. 96:2708-2717

Deviche, P., Bittner, S., Gao, S., Valle, S. 2017. Roles and mechanistic bases of glucocorticoid regulation of avian reproduction. Integr. Comp. Biol. 57:1184-1193.

Dixon, L., Duncan, I., Mason, G. 2008. What's in a peck? Using fixed action pattern morphology to identify the motivational basis of abnormal feather-pecking behaviour. Anim. Behav. 76:10351042.

Duncan, I.J.H. 1993. Welfare is to do with what animals feel. Journal of Agricultural and Environ. Ethics 6:8-14.

EFSA. 2010. Scientific Opinion on welfare aspects of the management and housing of the grandparent and parent stocks raised and kept for breeding purposes. The EFSA Journal 8:81.

Edney, A.T., Smith, P.M. 1986. Study of obesity in dogs visiting veterinary practices in the United Kingdom. Vet. Rec. 118:391-396.

Eitan, Y., Lipkin, E., Soller, M. 2014. Body composition and reproductive performance at entry into lay of anno 1980 versus anno 2000 broiler breeder females under fast and slow release from feed restriction. Poult. Sci. 93:1227-1235.

Ekmay, R.D., de Beer, M. Rosebrough, R.W., Richards, M.P., McMurtry, J.P., Coon, C.N. 2010. The role of feeding regimens in regulating metabolism of sexually mature broiler breeders. Poult. Sci. 89:1171-1181.

Ekmay, R.D., Salas, C., England, J., Cerrate, S., Coon, C.N. 2012. The effects of pullet body weight, dietary nonpyhtate phosphorus intake, and breeder feeding regimen on production performance, chick quality, and bone remodeling in broiler breeders. Poult. Sci. 91:948-964.

Epling, W.F., Pierce, W.D. 1988. Activity-based anorexia: a biobehavioral perspective. Int. J. Eating Dis. 7:475-485.

Enting, H., Boersma, W.J.A., Cornelissen, J., van Winden, S.C.L., Verstegen, M.W.A., van der Aar, P.J.. 2007. The effect of low-density broiler breeder diets on performance and immune status of their offspring. Poult. Sci. 86:282-290.

Fan, J.G., Zhong, L., Xu, Z.J., Tia, L.Y., Ding, X.D., Li, M.S., Wang, G.L. 2003. Effects of low-calorie diet on steatohepatitis in rats with obesity and hyperlipidemia. World J. Gastroenterology 9:20452049.

Fancher, B.I. 2014. What is the upper limit to commercially relevant body weight in modern broilers? Aviagen, Huntsville, USA.

FAO. 2020. http://www.fao.org/faostat/en/\#data/QC. 
Fattori, T.R., Wilson, H.R., Harms, R.H., Mather, F.B., Miles, R.D., Butcher, G.D. 1993. Response of broiler breeder females to feed restriction below recommended levels. 3. Characterizing the onset of sexual maturity. Poult. Sci. 72:2044-2051.

Ferguson, S.A., Paule, M.G. 1995. Lack of effect of prefeeding on food-reinforced temporal response differentiation and progressive ratio responding. Behav. Processes. 34:153-160.

Ferguson, S.A., Paule, M.G. 1997. Progressive ratio performance varies with body weight in rats. Behav. Processes 40:177-182.

Flanagan, J., Bissot, T., Hours, M.A., Moreno, B., Feugier, A., German, A.J., 2017. Success of a weight loss plan for overweight dogs: the results of an international weight loss study. PLoS. ONE. 12 (9).

Flanagan, J., Bissot, T., Hours, M.A., Moreno, B., Feugier, A., German, A.J., 2018. An international multi-centre cohort study of weight loss in overweight cats: differences in outcome in different geographical locations. PLoS. ONE 13 (7).

Fraser, D., Duncan, I.J. 1998. 'Pleasures', 'pains' and animal welfare: toward a natural history of affect. Anim. Welf. 7:383-396.

Fraser, D., Weary, D.M., Pajor, E.A., Milligan, B.N. 1997. A scientific conception of animal welfare that reflects ethical concerns. Anim. Welf. 6:187-205.

German, A.J. 2006. The growing problem of obesity in dogs and cats. J. Nutr. 136:1940S-1946S.

German, A.J., Luxmore, J., Holden, S.L., Morris, P.J., Biourge, V. 2015. Feeding obese dogs during weight loss is on average cost-neutral. J. Sm. Anim. Pract. 56:366-369.

Gossellin, J., Wren, J.A., Sunderland, S.L. 2007. Canine obesity: an overview. J. Vet. Pharmacol. Ther. 30:1-10.

Gous, R.M., Cherry, P. 2004. Effects of body weight at, and lighting regimen and growth curve to, 20 weeks on laying performance in broiler breeders. Br. Poult. Sci. 45:445-452.

Hart, R.W., Neumann, D.A., Robertson, R.T.E. 1995. Dietary Restriction: Implications for the Design and Interpretation of Toxicity and Carcinogenicity Studies. ILSI Press, Washington, USA.

Havenstein, G.B., Ferket, P.R., Qureshi, M.A. 2003a. Growth, livability, and feed conversion of 1957 versus 2001 broilers when fed representative 1957 and 2001 broiler diets. Poult. Sci. 82:15001508.

Havenstein, G.B., Ferket, P.R., Qureshi, M.A. 2003b. Carcass composition and yield of 1957 versus 2001 broilers when fed representative 1957 and 2001 broiler diets. Poult. Sci. 82:1509-1518.

Hawn, R. 2005. Taking on canine and feline obesity. Vet. Techn. 26:51-52.

Heck, A., Onagbesan, O. Tona, K., Metayer, S., Putterflam, J., Jego, Y., Trevidy, J.J., Decuypere, E., Williams, J., Picard, M., Bruggeman, V. 2004. Effects of ad libitum feeding on performance of different strains of broiler breeders. Br. Poult. Sci. 45:695-703.

Hess, R., Kass, P., Shofer, F., Van Winkle, T., Washabau, R. 1999. Evaluation of risk factors for fatal acute pancreatitis in dogs. J. Am. Vet. Med. Assoc. 214:46-51.

Hill, R.C., Lewis, D.D., Randell, S.C., Scott, K.C., Omori, M., Sundstrom, D.A., Jones, G.L., Speakman, J.R., Butterwick, R.F. 2005. Effect of mild restriction of food intake on the speed of racing greyhounds. Am. J. Vet. Res. 66:1065-1070.

Hill, R.C. 2009. Conference on multidisciplinary approaches to nutritional problems. Symposium on nutrition and health. Nutritional therapies to improve health: lessons from companion animals. Proceedings of the Nutrition Society 68:98-102.

Hocking, P.M., Waddington, D., Walker, M.A., Gilbert, A.B. 1989. Control of the development of the ovarian follicular hierarchy in broiler breeder pullets by food restriction during rearing. Br. Poult. Sci. 30:161-74.

Hocking, P.M., Maxwell, M.H., Mitchell, M.A. 1993. Welfare assessment of broiler breeder and layer females subjected to food restriction and limited access to water during rearing. $\mathrm{Br}$. Poult. Sci. 34:443-58.

Hocking, P.M., Maxwell, M.H., Mitchell, M.A. 1996. Relationships between the degree of food restriction and welfare indices in broiler breeder females. Br. Poult. Sci. 37:263-278.

Hocking, P.M., Maxwell, M.H., Robertson, G.W., Mitchell, M.A. 2001. Welfare assessment of modified rearing programs for broiler breeders. Br. Poult. Sci. 42:424-432.

Hocking, P.M., Bernard, R., Robertson, G.W. 2002. Effects of low dietary protein and different allocations of food during rearing and restricted feeding after peak rate of lay on egg production, fertility and hatchability in female broiler breeders. Br. Poult. Sci. 43:94-103.

Hocking, P.M. 2004. Roles of body weight and feed intake in ovarian follicular dynamics in broiler breeders at the onset of lay and after a forced molt. Poult. Sci. 83:2044-2050. 
Hocking, P.M., Jones, E., Picard, M. 2005. Assessing the welfare consequences of providing litter for feed-restricted broiler breeders. Br. Poult. Sci. 46:545-552.

Home Office. 1989. Code of Practice for the Housing and Care of Animals Used in Scientific Procedures. London: HMSO, UK.

Home Office. 2003. Home Office Guidance Note: Water and Food Restriction for Scientific Purposes. London: HMSO, UK.

Houston, D.K., Nicklas, B.J., Zizza, C.A. 2009. Weighty concerns: the growing prevalence of obesity among older adults. J. Am. Dietetic Assoc. 109:1886-1895.

Hubbard, 2017. Guide parent stock. http://www.hubbardbreeders.com/media/guide__ps_ classic_08_01_2016_imp_051137500_1634_22012016.pdf (Accessed date 24 March 2016).

Hy-Line. 2018. Management guide. Brown commercial layers.

Jones, B., Boissy, A. 2011. Fear and other negative emotions. In: Appleby, M.C. (Ed). Animal Welfare. CABI International, Wallingford, UK, pp 78-97.

Jones, E.K.M., Zaczek, V., Macleod, M., Hocking, P.M. 2004. Genotype, dietary manipulation and food allocation affect indices of welfare in broiler breeders. Br. Poult. Sci. 45:725-737.

Jovani, R., Rohwer. S. 2017. Fault bars in bird feathers: mechanisms, and ecological and evolutionary causes and consequences. Biol. Rev. 92:1113-1127.

Kealy, R.D., Lawler, D.F., Ballam, J.M., Mantz, S.J., Biery, D.N., Greeley, E.H. et al. 2002. Effects of diet restriction on life span and age-related changes in dogs. J. Am. Vet. Med. Assoc. 220:131520.

Katanbaf, M., Dunnington, E., Siegel, P. 1989. Restricted feeding in early and late-feathering chickens. 1. Growth and physiological responses. Poult. Sci. 68:344-351.

Kealy, R.D., Lawler, D.F., Ballam, J.M., Lust, G., Biery, D.N. et al. 2000. Evaluation of the effect of limited food consumption on radiographic evidence of osteoarthritis in dogs. J. Am. Vet. Med. Assoc. 217:1678-1680.

Kealy, R.D., Lawler, D.F., Ballam, J.M., et al. 2002. Effect of diet restriction on life span and agerelated changes in dogs. J. Am. Vet. Med. Assoc. 220:1315-1320.

Keeling, L.J. 2002. Behaviour of fowl and other domesticated birds. In: Jensen, P. (Ed). The ethology of Domestic Animals. An Introductory Text. CABI International, Wallingford, UK, pp 101-119

Keeling, L.J., Rushen, J., Duncan, I.J. 2011. Understanding animal welfare. In: Appleby, M.C. (Ed). Animal Welfare. CABI International, Wallingford, UK, pp 13-26.

Keenan, K.P., Smith, P.F., Ballam, G.C., Soper, K.A. 1994. The effects of dietary (caloric) restriction on rat aging, Survival, Pathology and Toxicology. Pathobiology of the Ageing Rat. Vol. II. Washington, DC: ILSI Press, USA.

Keenan, K.P., Laroque, P., Ballam, G.C., et al. 1996. The effects of diet, ad libitum overfeeding, and moderate dietary restriction on the rodent bioassay: the uncontrolled variable in safety assessment. Toxicol. Pathol. 24:757-768.

Keenan, K.P., Laroque, P., Dixit, R. 1998. Need for dietary control by caloric restriction in rodent toxicology and carcinogenicity studies. J. Toxicol. Environ. Health 1:135-48.

Keenan, K., Ballam, G., Soper, K. et al. 1999. Diet, caloric restriction, and the rodent bioassay. Toxicol. Sci. 52:24-34.

Keller, E., Sagols, E., Flanagan, J., Biourge, V., German, A.J. 2020. Use of reduced-energy content maintenance diets for modest weight reduction in overweight cats and dogs. Res. Vet. Sci. 131:194-205.

Ketelaars, E.H. 1992. Historie van de Nederlandse Pluimveehouderij. BDU, Barneveld, the Netherlands.

Kienzle, E., Bergler, R., Mandernach, A. 1998. A comparison of the feeding behavior and the humaneanimal relationship in owners of normal and obese dogs. J. Nutr. 128:2779S-2782S.

Kolonin, M.G., Saha, P.K., Chan, L., Pasqualini, R., Arap, W. 2004. Reversal of obesity by targeted ablation of adipose tissue. Nat. Med. 10:625-632.

Kostal, L., Savory, C.J., Hughes, B.O. 1992. Diurnal and individual variation in behaviour of restrictedfed broiler breeders. Appl. Anim. Behav. Sci. 32:361-374.

Knibbe, M.T. 1995. 'De opkomst van de intensieve pluimveeteelt in Nederland 1890-1930', Tijdschrift voor Sociaalwetenschappelijk Onderzoek van de Landbouw 10:55-75.

Kubíková, L., Výboh, P., Koštál, L. 2001. Behavioural, endocrine and metabolic effects of food restriction in broiler breeder hens. Acta Vet. Brno 70:247-257. 
Kyriazakis, I. 1994. The voluntary food intake and diet selection of pigs. In: Principles of Pig Science (Ed. by D.J.A. Cole, J. Wiseman, M.A. Varley), pp. 85-105. Nottingham: Nottingham University Press.

KWIN, 2021. Kwantitatieve Informatie Veehouderij 2020-2021. Wageningen Livestock Research, Wageningen, Nederland.

Laflamme, D.P. 2006. Understanding and managing obesity in dogs and cats. Vet. Clin. North. Am. Small. Anim. Pract. 36:1283-1295.

Lawler, D.F., Ballam, J.M., Meadows, R., Larson, B.T., Li, Q., Kealy, R.D. 2007. Influence of lifetime food restriction on selected hematology and clinical chemistry in dogs. Exp. Gerontol. 42:204-214.

Lawler, D.F., Larson, B.T., Ballam, J.M., Smith, G.K., Biery, D.N., Evans, R.H., Greeley, E.H., Segre, M., Stowe, H.D., Kealy, R.D. 2008. Diet restriction and ageing in the dog: major observations over two decades. Br. J. Nutr. 99:793-805.

Lawrence, A.B., Appleby, M.C., Illius, A.W., Macleod, H.A. 1989. Measuring hunger in the pig using operant conditioning: the effect of dietary bulk. Anim. Prod. 48:213-220.

Lawrence, A.B., Terlouw, E.M.C. 1993. A review of the behavioural factors involved in the development and continued performance of stereotypic behaviors in pigs. J. Anim. Sci. 71:28152825.

Lawrence, A.B., Terlouw, E.M.C., Kyriazakis, I. 1993. The behavioral effects of undernutrition in confined farm animals. Proc. Nutr. Soc. 52:219-229.

Leeson, S., Summers, J. 1982. Consequence of increased feed allotment for growing broiler breeder pullets as a means of stimulating early maturity. Poult. Sci. 62:6-11.

Leeson, S., Summers, J. 1985. Effect of cage versus floor rearing and skip-a-day versus every-day feed restriction on performance of dwarf broiler breeders and their offspring. Poult. Sci. 64:17421749.

Leeson, S., Summers, J.D. 2000. Broiler Breeder Production. Unviersity Books, Guelph, Canada.

Lieberman, L.S. 2006. Evolutionary and anthropological perspectives on optimal foraging in obesogenic environments. Appetite 47:3-9.

Lohmann, 2016. Management Guide. Lohmann Tierzucht GmbH, Cuxhaven, Germany.

Lund, E.M., Armstrong, P.J., Kirk, C.A., Klausner, J. 2005. Prevalence and risk factors for obesity in adult cats from private US veterinary practices. Int. J. Appl. Res. Vet. Med. 3:88-96.

Lund, E., Armstrong, P.J., Kirk, C.A., Klausner, J.S. 2006. Prevalence and risk factors for obesity in adult dogs from private US veterinary practices. Int. J. Appl. Res. Vet. Med. 4:177-186.

Mao, J., Xia, Z., Chen, J., Yu, J. 2013. Prevalence and risk factors for canine obesity surveyed in veterinary practices in Beijing, China. Prev. Vet. Med. 112:438-442.

Marshall, W.G., Bockstahler, B.A., Hulse, D.A., Carmichael, S. 2009. A review of osteoarthritis and obesity: current understanding of the relationship and benefit of obesity treatment and prevention in the dog. Vet. Comp. Orthopaedics Traumatol. 22:339-345.

Mason, G.J., 1991. Stereotypies and suffering. Behav. Proc. 25:103-115.

Mason, G., Mendl, M. 1993. Why is there no simple way of measuring animal welfare? Anim. Welf. 2:310-319.

Mason, G.J., Latham, N. 2004. Can't stop, won't stop: is stereotypy a reliable animal welfare indicator?. Proceedings of the UFAW International Symposium Science Service Animal Welfare (eds. Kirkwood, J.K., Roberts, E.A., and Vickery, S.) S57-S69.

Mason, G.J., Rushen, J. 2006. Stereotypic Animal Behaviour: Fundamentals and Applications to Welfare, CABI Pub.

Mason, G., Clubb, R., Latham, N., Vickery, S. 2006. Why and how should we use environmental enrichment to tackle stereotypic behavior? Appl. Anim. Behav. Sci. 102:163-188.

Masoro, E.J. 2005. Overview of caloric restriction and aging. Mech. Aging. Dev. 126:913-22.

Mba, E., Renema, R.A., Pishnamazi, A., Zuidhof, M.J. 2010. Do dietary protein:energy ratios modify growth and frame size of young broiler breeder females? Poult. Sci. 89(Suppl. 1):122. (Abstr.)

McGreevy, P.D., Thomson, P.C., Pride, C., et al. 2005. Prevalence of obesity in dogs examined by Australian veterinary practices and the risk factors involved. Vet Rec 156:695-702.

Mellor, D.J. 2016. Updating animal welfare thinking: Moving beyond the "Five Freedoms" towards "a Life Worth Living". Animal 6:21.

Mellor, E., Brilot, B., Collins, S. 2018. Abnormal repetitive behaviours in captive birds: a Tinbergian review. Appli. Anim. Behav. Sci. 198:109-120.

Mench, J.A. 2002. Broiler breeders: feed restriction and welfare. World's Poult. Sci. J. 58:23-30. 
Molnár, A., Kempen, I., Sleeckx, N., Zoons, J., Maertens, L., Ampe, B., Buyse, J., Delezie, E. 2018. Effects of split feeding on performance, egg quality, and bone strength in brown laying hens in aviary system. J. Appl. Poult. Res. 27:401-415.

Montiel, E.R. 2016. Influence of feeding programs on innate and adaptive immunity in broiler breeders. PhD Diss. The University of Georgia, Athens, Georgia, USA.

Moradi, S., Zaghari, M., Shivazad, M., Osfoori, R., Mardi, M. 2013. The effect of increasing feeding frequency on performance, plasma hormones and metabolites, and hepatic lipid metabolism of broiler breeder hens. Poult. Sci. 92:1227-1237.Mormède, P., Andanson, S., Aupérin, B., Beerda, B., Guémené, D., Malmkvist, J., Manteca, X., Manteuffel, G., Prunet, P., van Reenen, C.G. 2007. Exploration of the hypothalamic-pituitary-adrenal function as a tool to evaluate animal welfare. Physiol. Behav. 92:317-339.

Morrissey, K.L.H., Widowski, T., Leeson, S., Sandilands, V., Arnone, A., Torrey, S. 2014a. The effect of dietary alterations during rearing on feather condition in broiler breeder females. Poult. Sci. 93:1636-1643.

Morrissey, K.L.H., Widowski, T., Leeson, S., Sandilands, V., Arnone, A., Torrey, S. 2014b. The effect of dietary alterations during rearing on growth, productivity, and behaviour in broiler breeder females. Poult. Sci. 93:285-295.

Naguib, M., Nemitz, A., Gil, D. 2006. Maternal developmental stress reduces reproductive success of female offspring in zebra finches. Proceedings of the Royal Society of London B: Biol. Sci. 273:1901-1905.

Neeteson-van Nieuwenhoven, A.M., Knap, P., Avendano, S. 2013. The role of sustainable commercial pig and poultry breeding for food security. Anim. Frontiers 3:52-57.

Newberry, R.C., Estevez, I. Keeling, L.J. 2001. Group size and perching behaviour in young domestic fowl. Appl. Anim. Behav. Sci. 73:117-129.

Newberry, R.C., Keeling, L.J., Estevez, I., Bilčík, B. 2007. Behaviour when young as a predictor of severe feather pecking in adult laying hens: the redirected foraging hypothesis revisited. Appl. Anim. Behav. Sci. 107:262-274.

Nielsen, B.L., Thodberg, K., Malmkvist, J., Steenfeldt, S. 2011. Proportion of insoluble fibre in the diet affects behavior and hunger in broiler breeders growing at similar rates. Animal 5:1247-1258.

Novogen. 2017. Management guide Novogen layers. Le Foeil, Quitin, France.

Odihambo Mumma, J., Thaxton, J., Vizzier-Thaxton, Y., Dodson, W. 2006. Physiological stress in laying hens. Poult. Sci. 85:761-769.

Painter, R.C., Roseboom, T.J., Bleker, O.P. 2005. Prenatal exposure to the Dutch famine and disease in later life: An overview. Reprod. Toxicol. 20:345-352.

Paul, E.S., Harding, E.J., Mendl, M. 2005. Measuring emotional processes in animals: the utility of a cognitive approach. Neurosci. Biobehav. Rev. 29:469-491.

Rabello, C.B.V., Sakomura, N.K., Longo, F.A., Couto, H.P., Pacheco, C.R., Fernandes, J.B.K. 2006. 'Modelling energy utilisation in broiler breeder hens'. Bri. Poult. Sci. 47:622-631.

Renema, R.A., Robinson, F.E., Goerzen, P. 2001a. Effects of altering growth curve and age at photostimulation in female broiler breeders. 1. Reproductive development. Can. J. Anim. Sci. $81: 467-476$

Renema, R.A., Robinson, F.E., Goerzen, P., Zuidhof, M.J. 2001b. Effects of altering growth curve and age at photostimulation in female broiler breeders. 2. Egg production parameters. Can. J. Anim. Sci. 81:477-486.

Renema, R.A., Robinson, F.E., Zuidhof, M.J. 2007. Reproductive efficiency and metabolism of female broiler breeders as affected by genotype, feed allocation, and age at photostimulation. 2. Sexual maturation. Poult. Sci. 86:2267-2277.

Ritskes-Hoitinga, J., Chwalibog, A. 2003. Nutrients requirements, experimental design and feeding schedules in animal experimentation. In: Handbook of Laboratory Animal Science, Vol. 1., 2nd edn. Eds Hau, J., van Hoosier, G., pp. 281-310. CRC Press, London, UK.

Ritskes-Hoitinga, J., Grooten, H.N., Wienk, K.J. et al. 2004. Lowering dietary phosphorus concentrations reduces kidney calcification, but does not adversely affect growth, mineral metabolism, and bone development in growing rabbits. Br. J. Nutr. 91:367-376.

Ritskes-Hoitinga, M., Strubbe, J.H. 2004. Nutrition and animal welfare. In: The Welfare of Laboratory Animals. Ed. Kaliste, E., pp. 51-80. Kluwer Academic Publishers, Dordrecht, the Netherlands. 
Robinson, F.E., Zuidhof, M.J., Renema, R.A. 2007. Reproductive efficiency and metabolism of female broiler breeders as affected by genotype, feed allocation, and age at photostimulation. 1. Pullet growth and development. Poult. Sci. 86:2256-2266.

Roseboom, T.J., de Rooij, S.R., Painter, R.C. 2006. The Dutch famine and its long-term consequences for adult health. Early Hum. Dev. 82:485-491.

Rougoor, C., van der Schans, F. 2019. Vergelijking milieueffecten vleeskuikenconcepten. CLM rapport 982. Culemborg, Nederland.

Rushen, J. 1985. Stereotypies, aggression and the feeding schedules of tethered sows. Appl. Anim. Behav. Sci. 14:137-147.

Sahraei, M. 2012. Feed restriction in broiler chicken production. Biotechnology Anim. Husb. 28:333352.

Sakomura, N.K., Silva, R., Couto, H.P., Coon, C., Pacheco, C.R. 2003. Modeling metabolizable energy utilization in broiler breeder pullets. Poult. Sci. 82:419-427.

Sallander, M., Hagberg, M., Hedhammar, A., Rundgren, M., Lindberg, J.E. 2010. Energy-intake and activity risk factors for owner-perceived obesity in a defined population of Swedish dogs. Prev. Vet. Med. 96:132-141.

Sandilands, V., Savory C.J., Powell, K. 2004a. Preen gland function in layer fowls: factors affecting morphology and feather lipid levels. Comp. Bioch. Physiol. 137:217-225.

Sandilands, V., Powell, K., Keeling, L.J., Savory, C.J. 2004b. Preen gland function in layer fowls: factors affecting preen oil fatty acid composition, Br. Poult. Sci. 45:109-115.

Sandilands, V., Tolkamp, B.J., Kyriazakis, I. 2005. Behaviour of food restricted broilers during rearing and lay - effects of an alternative feeding method. Physiol. Behav. 85:115-123.

Sandilands, V., Tolkamp, B.J., Savory, C.J., Kyriazakis, I. 2006. Behaviour and welfare of broiler breeders fed qualitatively restricted diets during rearing: Are there viable alternatives to quantitative restriction? Appl. Anim. Behav. Sci. 96:53-67.

Savenije, B., Strubbe, J., Ritskes-Hoitinga, M. 2010. Nutrition, Feeding and Animal Welfare. The UFAW Handbook of the Care and Management of Laboratory and Other Research Animals. 8th edn. Oxford: Wiley-Blackwell, UK.

Savory, C.J., Wood-Gush, D.G.M., Duncan, I.J.H. 1978. Feeding behaviour in a population of domestic fowls in the wild. Appl. Anim. Ethology 4:13-27.

Savory, C.J., Maros, K., Rutter, S.M. 1993. Assessment of hunger in growing broiler breeders in relation to a commercial restricted feeding programme. Anim. Welf. 2:131-152.

Savory, C.J., Maros, K. 1993. Influence of degree of food restriction, age and time of day on behaviour of broiler breeder chickens. Behav. Processes 29:179-190.

Savory, C.J., Kostal, L. 1996. Temporal patterning of oral stereotypies in restricted-fed fowls: 1. investigations with a single daily meal. Int. J. Comp. Psychol. 9:117-139.

Savory, C.J., Hocking, P.M., Mann, J.S., Maxwell, M.H. 1996. Is broiler breeder welfare improved by using qualitative rather than quantative food restriction to limit growth rate? Anim. Welf. 5:105127.

Savory, C.J., Mann, J.S. 1997. Is there a role for corticosterone in expression of abnormal behaviour in restricted-fed fowls? Physiol. Behav. 62:7-13.

Savory, C.J., Lariviere, J.M. 2000. Effects of qualitative and quantitative food restriction treatments on feeding motivational state and general activity level of growing broiler breeders. Appl. Anim. Behav. Sci. 69:135-147.

Scanes, C.G. 2016. Biology of stress in poultry with emphasis on glucocorticoids and the heterophil to lymphocyte ratio. Poult. Sci. 95:2208-2215.

Sheppard, K.C., Duncan, I.J.H. 2011. Feeding motivation on the incidence of floor eggs and extraneously calcified eggs laid by broiler breeder hens. Br. Poult. Sci. 52:20-29.

Schrader, L., Müller, B. 2009. Night-time roosting in the domestic fowl - the height matters. Appl. Anim. Behav. Sci. 121:179-183.

Schwitzer, C., Kaumanns, W. 2001. Body weights of ruffed lemurs (Varecia variegata) in European zoos with reference to the problem of obesity. Zoo Biol. 20:261-269.

Soltanmoradi, M.G., Seidavi, A., Dadashbeiki, M., Delgado, F., Gamboa, S. 2013. Effect of time, amount and frequency of feeding on total egg production, fertility and hatchability in broiler breeders. Arch. Tierzucht: Arch. Anim. Breed. 56:102. 
Spradley, J.M., Freeman, M.E., Wilson, J.L., Davis, A.J. 2008. The influence of a twice-a-day feeding regimen after photostimulation on the reproductive performance of broiler breeder hens. Poult. Sci. 87:561-568.

Stevens, L. 1996. Lipids and their metabolism, in: Avian Biochemistry and Molecular Biology, pp. 4664 (Cambridge, Cambridge University Press).

Strubbe, J.H. 2003. Hunger, meals and obesity. In: Encyclopedia of Cognitive Science, Vol 2 . Ed. Nadel, L., pp. 432-437. Nature Publishing Group, London, UK.

Sun, J., Coon, C.N. 2005. The effects of body weight, dietary fat, and feed withdrawal rate on the performance of broiler breeders. J. Appl. Poult. Res. 14:728-739.

Sun, J.M., Richards, M.P., Rosebrough, R.W., Ashwell, C.M., McMurtry, J.P., Coon, C.N. 2006. The relationship of body composition, feed intake, and metabolic hormones for broiler breeder females. Poult. Sci. 85:1173-1184.

Tacken, G.M.L., van Leeuwen, M.G.A., Koole, B., van Horne, P.L.M., de Vlieger, J.J., de Bont, C.J.A.M., 2003. Ketenconsequenties van de uitbraak van vogelpest. Rapport 6.03.06, LEI, Den Haag.

Taherkhani, R., Zaghari, M., Shivazad, M., Zare Shahneh, A. 2010. A twice-a-day feeding regimen optimizes performance in broiler breeder hens. Poult. Sci. 89:1692-1702.

Thompson, A.L. 1964. Oil gland. In: Thompson, A.L. (Ed.), A New Dictionary of Birds. Thomas Nelson and Sons Ltd, Edinburgh, pp. 551-552.

Tolkamp, B.J., Sandilands, V., Kyriazakis, I., 2005. Effects of qualitative feed restriction during rearing on the performance of broiler breeders during rearing and lay. Poult. Sci. 84, 1286-1293.

UN. 2019. Growing at a slower pace, world population is expected to reach 9.7 billion in 2050 and could peak at nearly 11 billion around 2100 .

https://www.un.org/development/desa/en/news/population/world-population-prospects2019.html

van der Haar, J., van Voorst, S. 2001. Welzijn (opfok) vleeskuikenouderdieren bij tweemaal daags voeren. Praktijkonderzoek Veehouderij - Pluimvee. Lelystad, The Netherlands. pp: 21-25.

van der Klein, S., Silva, F., Kwakkel, R.P., Zuidhof, M. 2016. The effect of quantitative feed restriction on allometric growth in broilers. Poult. Sci. 96:118-126.

van der Waaij, L., Theunissen, B. 2017. 'De meest efficiënte kip ter wereld' De Nederlandse legkippenfokkerij in de twintigste eeuw. Tijdschrif voor Wetenschaps- en Universiteitsgeschiedenis 10:61-85.

van Emous, R.A., Kwakkel, R.P., van Krimpen, M.M., Hendriks, W.H. 2013. Effects of growth pattern and dietary protein levels during rearing on body composition and performance in broiler breeder females during the rearing and laying period. Poult. Sci. 92:2091-2100.

van Emous, R.A., Kwakkel, R.P., van Krimpen, M.M., Hendriks, W.H. 2014. Effects of growth pattern and dietary protein level during rearing on feed intake, eating time, eating rate, behavior, plasma corticosterone concentration, and feather cover in broiler breeder females during the rearing and laying period. Appl. Anim. Behav. Sci. 150:44-54.

van Emous, R.A. 2015. Body composition and reproduction in broiler breeders: impact of feeding strategies. PhD Diss. Wageningen University, Wageningen, the Netherlands.

van Emous, R.A., Kwakkel, R.P., van Krimpen, M.M., Hendriks, W.H. 2015a. Effects of different dietary protein levels during rearing and different dietary energy levels during lay on behaviour and feather cover in broiler breeder females. Appl. Anim. Behav. Sci. 168:45-55.

van Emous, R.A., Kwakkel, R.P., van Krimpen, M.M., Hendriks, W.H. 2015b. Effects of dietary protein levels during rearing and different dietary energy levels during lay on body composition and reproduction in broiler breeder females. Poult. Sci. 94:1030-1042.

van Emous, R.A. 2018. Meer kuikens door minder onrust. Pluimveehouderij 1 maart 2018 28-30.

van Emous, R.A., A.J.W. Mens. 2019. Tweemaal per dag voeren verbetert de uniformiteit halverwege de opfok. Pluimveehouderij.

van Emous, R.A., 2019. Fosfaatexcretie van minivleeskuikenmoederdieren van trager groeiende vleeskuikens. Rapport 1174. Wageningen University \& Research.

van Horne, P.L.M., Vermeij, I., Ellen, H.H.. 2004. Concurrentiepositie van de Nederlandse broedeisector. Rapport 2.04.01, LEI, Den Haag, Nederland.

van Krimpen, M., de Jong, I.C. 2014. Impact of nutrition on welfare aspects of broiler breeder flocks. World's Poult. Sci. J. 70:139-150.

Veissier, I., Boissy, A. 2007. Stress and welfare: two complementary concepts that are intrinsically related to the animal's point of view. Physiol. Behav. 92:429-433. 
Vignale, K., Caldas, J.V., England, J.A., Boonsinchai, N., Sodsee, P., Putsakum, M., Pollock, E.D., Dridi, S., Coon, C.N. 2016. The effect of four different feeding regimens from rearing period to sexual maturity on breast muscle protein turnover in broiler breeder parent stock. Poult. Sci. 96:12191227.

Vitousek, K.M., Manke, F.P., Gray, J.A., Vitousek, M.N. 2004. Caloric restriction for longevity: II. The systematic neglect of behavioural and psychological outcomes in animal research. Eur. Eating Dis. Rev. 12:338-360.

West, D.B., York, B. 1998. Dietary fat, genetic predisposition, and obesity: lessons from animal models. Am. J. Clin. Nutr. 67:505S-512S.

Wood-Gush, D.G.M., Duncan, I.J.H., Savory, C.J. 1978. Observations on the social behaviour of domestic fowl in the wild. Bio. Behav. 3:193-205.

Zoran, D.L., 2010. Obesity in dogs and cats: A metabolic and endocrine disorder. Vet. Clin. Small. Anim. 40:221-239.

Zuidhof, M.J., Robinson, F.E., Feddes, J.J.R., Hardin, R.T. 1995. The effects of nutrient dilution on the wellbeing and performance of female broiler breeders. Poult. Sci. 74:441-456.

Zuidhof, M.J., Renema, R.A., Robinson, F.E. 2007. Reproductive efficiency and metabolism of female broiler breeders as affected by genotype, feed allocation, and age at photostimulation. 3. Reproductive efficiency. Poult. Sci. 86:2278-86.

Zuidhof, M.J., Schneider, B.L., Carney, V.L., Korver, D.R., Robinson, F.E. 2014. Growth, efficiency, and yield of commercial broilers from 1957, 1978, and 2005. Poult. Sci. 93:2970-2982.

Zuidhof, M.J., Holm, D.E., Renema, R.A., Jalal, M.A., Robinson, F.E. 2015. Effects of broiler breeder management on pullet body weight and carcass uniformity. Poult. Sci. 94:1389-1397.

Zuidhof, M.J., Fedorak, M.V., Ouellette, C.A., Wenger, I.I. 2017. Precision feeding: Innovative management of broiler breeder feed intake and flock uniformity. Poult. Sci. 96:2254-2263.

Zuidhof, M.J. 2018. Lifetime productivity of conventionally and precision-fed broiler breeders. Poult. Sci. 97:3921-3937. 


\section{Bijlage 1 Overzicht literatuur effecten voercontrole op fysiologie}

\begin{tabular}{|c|c|c|c|c|c|}
\hline Referentie & Merk en periode & Behandelingen & Leeftijd metingen & Test & Effect \\
\hline $\begin{array}{l}\text { Katanbaf et al. } \\
\text { (1989) }\end{array}$ & NA / 0-65 wk & VC vs. AL dieren ${ }^{1}$ & $8 \mathrm{wk}$ & Plasma glucose & Lager voor VC vs. AL dieren \\
\hline \multirow[t]{3}{*}{$\begin{array}{l}\text { Hocking et al. } \\
(1996)\end{array}$} & Ross $1 / 1-18$ wk & $\begin{array}{l}\mathrm{VC}, \mathrm{AL}, 25,40,55,70 \text { en } \\
85 \% \text { van ad libitum }\end{array}$ & 12 en 18 wk & $\begin{array}{l}\text { Plasma corticosteron } \\
\text { concentratie }\end{array}$ & Lichtere dieren: hoger corticosteron \\
\hline & & & & $\mathrm{H} / \mathrm{L} \mathrm{ratio}^{2}$ & Lichtere dieren: hoger $\mathrm{H} / \mathrm{L}$ ratio \\
\hline & & & & $\mathrm{B} / \mathrm{L} \mathrm{ratio}^{2}$ & Lichtere dieren: hoger $\mathrm{B} / \mathrm{L}$ ratio \\
\hline \multirow[t]{3}{*}{$\begin{array}{l}\text { Savory et al. } \\
(1996)\end{array}$} & Ross 1 / 2-10 wk & $\begin{array}{l}\text { VC, } 2 \times \text { VC niveau, AL, } \\
\text { Verschillende ingrediënten } \\
(\text { o.a. } \mathrm{OH}, \mathrm{CaP})^{3}\end{array}$ & 6 en $10 \mathrm{wk}$ & $\begin{array}{l}\text { Plasma corticosteron } \\
\text { concentratie }\end{array}$ & Hoger cort bij VC vs. AL \\
\hline & & & & $\mathrm{H} / \mathrm{L}$ ratio & Geen effect \\
\hline & & & & $\mathrm{B} / \mathrm{L}$ ratio & Geen effect \\
\hline $\begin{array}{l}\text { Savory en Mann } \\
(1997)\end{array}$ & $\begin{array}{l}\text { Ross } 1 \text { (individueel) / } \\
6-10 \mathrm{wk}\end{array}$ & $\begin{array}{l}4 \text { verschillende } \\
\text { experimenten }\end{array}$ & 6 en $10 \mathrm{wk}$ & $\begin{array}{l}\text { Plasma corticosteron } \\
\text { concentratie }\end{array}$ & Meer voercontrole: hoger cort niveau \\
\hline \multirow[t]{2}{*}{$\begin{array}{l}\text { Hocking et al. } \\
(2001)\end{array}$} & Ross 308 / 1-24 wk & $\begin{array}{l}\text { VC, aangepast VC en AL } \\
\text { Hoog en laag eiwit }\end{array}$ & $6,12,18,24 \mathrm{wk}$ & $\begin{array}{l}\text { Plasma corticosteron } \\
\text { concentratie }\end{array}$ & Opfok: AL lager cort dan VC en aangepast VC \\
\hline & & & & $\mathrm{H} / \mathrm{L}$ ratio & $H / L$ ratio lager bij AL 6 wk en hoger 24 wk \\
\hline $\begin{array}{l}\text { van der Haar en } \\
\text { van Voorst (2001) }\end{array}$ & Cobb 500 / 4-24 wk & $\begin{array}{l}\text { Twee- vs. eenmaal per dag } \\
\text { voer verstrekken }\end{array}$ & $12,18 \mathrm{wk}$ & Corticosteron concentratie & $\begin{array}{l}\text { Hoger corticosteron conc. op } 12 \text { wk bij tweemaal } \\
\text { voeren. Bloed werd tussen voerbeurten getapt. } \\
\text { Geen verschil op } 18 \mathrm{wk}\end{array}$ \\
\hline
\end{tabular}




\begin{tabular}{|c|c|c|c|c|c|}
\hline Referentie & Merk en periode & Behandelingen & Leeftijd metingen & Test & Effect \\
\hline \multirow[t]{3}{*}{$\begin{array}{l}\text { de Jong et al. } \\
(2002)\end{array}$} & Hybro / 3-12 wk & VC vs. AL & $3,6,9 \mathrm{wk}$ & $\begin{array}{l}\text { Plasma corticosteron } \\
\text { concentratie }\end{array}$ & $\begin{array}{l}\text { VC gaf hogere plasmacorticosteron concentraties op } \\
6 \text { en } 9 \text { weken leeftijd }\end{array}$ \\
\hline & & & $3,6,9 \mathrm{wk}$ & $\mathrm{H} / \mathrm{L}$ ratio & Geen verschillen. \\
\hline & & & $3,6,9 \mathrm{wk}$ & Cort conc restrain test & $\begin{array}{l}\text { VC gaf een hogere corticosteron reactie na } 5 \\
\text { minuten vasthouden. }\end{array}$ \\
\hline \multirow[t]{4}{*}{$\begin{array}{l}\text { de Jong et al. } \\
(2003)\end{array}$} & $\begin{array}{l}\text { Hybro en JA57 / 3-8 } \\
\text { wk }\end{array}$ & $\begin{array}{l}\text { Hybro: } 90,70,50,35 \text { en } \\
25 \% \text { van ad libitum (AL) } \\
\text { opname en } A L . \\
\text { JA57: } 70 \% \text { van } A L \text { en } A L\end{array}$ & 7 wk & $\begin{array}{l}\text { Plasma corticosteron } \\
\text { concentratie }\end{array}$ & $\begin{array}{l}\text { Significant hoger plasma cort conc bij meer VC bij } \\
\text { Hybro en JA57 }\end{array}$ \\
\hline & & & $7 \mathrm{wk}$ & Plasma glucose concentratie & $\begin{array}{l}\text { Geen verschil in glucose conc. Wel lagere glucose } \\
\text { conc AL vs. VC }\end{array}$ \\
\hline & & & 7 wk & Plasma NEFA concentratie & Lagere NEFA conc bij meer VC \\
\hline & & & $7 \mathrm{wk}$ & Glucose/NEFA verhouding & Hogere glucose/NEFA ratio bij meer VC \\
\hline \multirow[t]{4}{*}{$\begin{array}{l}\text { de Jong et al. } \\
(2005 a)\end{array}$} & Hybro G / 2-8 wk & $\begin{array}{l}\text { Tweemaal daags voeren en } \\
\text { voer op strooisel }\end{array}$ & 7 wk & $\begin{array}{l}\text { Plasma corticosteron } \\
\text { concentratie }\end{array}$ & Geen effect \\
\hline & & & 7 wk & Plasma glucose concentratie & $\begin{array}{l}\text { Glucose hoger bij dieren eenmaal daags gevoerd } \\
\text { werden in voergoot vs. tweemaal daags (goot of } \\
\text { strooisel) }\end{array}$ \\
\hline & & & $7 \mathrm{wk}$ & Plasma NEFA concentratie & Geen effect \\
\hline & & & $7 \mathrm{wk}$ & Glucose/NEFA verhouding & Geen effect \\
\hline \multirow[t]{5}{*}{$\begin{array}{l}\text { de Jong et al. } \\
(2005 b)\end{array}$} & Cobb 500 / 4-24 wk & $\begin{array}{l}\text { Laag energetische voeders } \\
(-12 \% \text { en }-23 \%)\end{array}$ & 6,10 en $26 \mathrm{wk}$ & $\begin{array}{l}\text { Plasma corticosteron } \\
\text { concentratie }\end{array}$ & Geen effect \\
\hline & & & 6,10 en $26 \mathrm{wk}$ & Plasma glucose concentratie & Laagste glucose op 26 wk voor $-23 \%$ voer \\
\hline & & & 6,10 en $26 \mathrm{wk}$ & Plasma NEFA concentratie & $\begin{array}{l}\text { Hoogste NEFA controle voer } 10 \mathrm{wk} \text { en laagste voor - } \\
23 \% \text { voer op } 26 \mathrm{wk}\end{array}$ \\
\hline & & & $6,10,26 \mathrm{wk}$ & Glucose/NEFA verhouding & Lagere glucose/NEFA voor controle voer \\
\hline & & & $6,10,26,40 \mathrm{wk}$ & $\mathrm{H} / \mathrm{L}$ ratio & $\begin{array}{l}\text { Geen effect tussen } 6 \text { en } 26 \text { wk. Op } 40 \text { wk hogere } \\
\text { ratio voor }-23 \% \text { voer }\end{array}$ \\
\hline
\end{tabular}




\begin{tabular}{|c|c|c|c|c|c|}
\hline Referentie & Merk en periode & Behandelingen & Leeftijd metingen & Test & Effect \\
\hline \multirow[t]{2}{*}{$\begin{array}{l}\text { Sandilands et al. } \\
(2005)\end{array}$} & Ross 308 / 1-44 wk & VC, AL voer met $\mathrm{CaP}$ en $\mathrm{OH}$ & $5,11,19,34,44 \mathrm{wk}$ & $\begin{array}{l}\text { Plasma corticosteron } \\
\text { concentratie }\end{array}$ & Geen effect \\
\hline & & 2 voeders & $5,11,19,34,44 \mathrm{wk}$ & Witte bloed cellen & Geen effect \\
\hline \multirow[t]{3}{*}{$\begin{array}{l}\text { Sandilands et al. } \\
(2006)\end{array}$} & Ross 308 / 1-20 wk & $\begin{array}{l}\text { VC, AL voer met } \\
\text { verschillende doseringen } \\
\text { CaP en } \mathrm{OH}\end{array}$ & $6,12,18 \mathrm{wk}$ & $\begin{array}{l}\text { Plasma corticosteron } \\
\text { concentratie }\end{array}$ & $\begin{array}{l}\text { In } 1 \text { behandeling verhoogd (probleem met } \\
\text { lichaamsgewicht) }\end{array}$ \\
\hline & & 6 voeders & $6,12,18 \mathrm{wk}$ & Witte bloed cellen & Geen effect \\
\hline & & & $6,12,18 \mathrm{wk}$ & $\mathrm{H} / \mathrm{L}$ ratio & Geen effect \\
\hline $\begin{array}{l}\text { van Emous et al. } \\
(2014)\end{array}$ & Ross 308 / 3-40 wk & $\begin{array}{l}\text { Hoog en laag eiwit gehalte } \\
\text { opfok en hoog en laag } \\
\text { gewicht opfokperiode }\end{array}$ & $11,16,21,26 \mathrm{wk}$ & $\begin{array}{l}\text { Plasma corticosteron } \\
\text { concentratie }\end{array}$ & $\begin{array}{l}\text { Lager corticosteron concentratie op } 16 \text { wk voor hoog } \\
\text { gewicht. } \\
\text { Geen andere effecten. }\end{array}$ \\
\hline \multirow[t]{4}{*}{$\begin{array}{l}\text { Arrazola et al. } \\
(2019)\end{array}$} & Ross 308 / 3-22 wk & $\begin{array}{l}\text { Controle voer, alternatief } \\
\text { (soja hullen +CaP), } 4 / 3 \\
\text { schema en verschillende } \\
\text { voerprogramma's }\end{array}$ & $5,11,18,21 \mathrm{wk}$ & $\begin{array}{l}\text { Plasma corticosteron } \\
\text { concentratie }\end{array}$ & $\begin{array}{l}\text { Geen effect behandeling maar wel hoger bij voerloze } \\
\text { dagen }\end{array}$ \\
\hline & & & $5,11,18,21 \mathrm{wk}$ & Plasma glucose concentratie & $\begin{array}{l}\text { Wisselende effecten. Meestal hoogst voor } 4 / 3 \text { op } \\
\text { voerdagen }\end{array}$ \\
\hline & & & $5,11,18,21 \mathrm{wk}$ & $\mathrm{H} / \mathrm{L}$ ratio & Geen effect \\
\hline & & & $5,11,18,21 \mathrm{wk}$ & $\mathrm{B} / \mathrm{L}$ ratio & Ratio op jongere leeftijd hoger bij controle voer \\
\hline
\end{tabular}

${ }_{1} \mathrm{VC}=$ voercontrole, $\mathrm{AL}=$ Ad libitum voeding

${ }^{2} \mathrm{H} / \mathrm{L}=$ heterofielen/lymfocyten ratio, $\mathrm{B} / \mathrm{L}=$ basofielen/lymfocyten ratio

${ }^{3} \mathrm{OH}=$ oat hulls (haverdoppen), $\mathrm{CaP}=$ calciumpropionaat (eetlustremmer) 


\section{Bijlage 2 Overzicht literatuur effecten voercontrole op gedrag}

\begin{tabular}{|c|c|c|c|c|c|}
\hline Referentie & Merk en periode & Behandelingen & Leeftijd metingen & Test & Effect \\
\hline $\begin{array}{l}\text { Savory et al. } \\
(1993)\end{array}$ & Ross 1 / 2-21 wk & VC, $2 x$ niveau $V C$ en $(A L)$ & $5-8-11-14-17-20 w k$ & 'Operant conditioning' ${ }^{1}$ & $\begin{array}{l}\text { Motivatie tot voer opnemen is } 3,6 \text { en } 1,9 \text { groter bij VC } \\
\text { en } 2 x \text { VC vs. AL dieren. }\end{array}$ \\
\hline & & & $2-21 w k$ & Voeropname tijd (pellet) & $\begin{array}{l}\text { Norm: } 6-8 \text { u } 1^{\mathrm{e}} w \mathrm{k}, 3-4 \mathrm{u} 2^{\mathrm{e}} \mathrm{wk}, 20-30 \mathrm{~min} 3^{\mathrm{e}} \mathrm{wk}, 10- \\
20 \mathrm{~min} 4^{\mathrm{e}} \mathrm{wk} \text {, minder dan } 10 \mathrm{~min} \text { daarna }\end{array}$ \\
\hline $\begin{array}{l}\text { Savory en Maros } \\
(1993)\end{array}$ & Ross 1 / 2-21 wk & VC, $2 \times V C$ niveau en ( $A L)$ & $6,9,12,15,18 \mathrm{wk}$ & Algemeen gedrag & $\begin{array}{l}\text { VC en 2xVC: meer lopen voor voeren en drinken, } \\
\text { meer vloerpikken en zitten na voeren. }\end{array}$ \\
\hline $\begin{array}{l}\text { Hocking et al. } \\
(1996)\end{array}$ & Ross 1 / 1-18 wk & $\begin{array}{l}\text { VC, } A L, 25,40,55,70 \text { en } \\
85 \% \text { van ad libitum }\end{array}$ & $6,12,18 \mathrm{wk}$ & Algemeen gedrag & $\begin{array}{l}\text { Meer rusten bij zwaardere dieren } \\
\text { Op } 18 w k \text { : meer pik activiteiten bij lager gewicht }\end{array}$ \\
\hline $\begin{array}{l}\text { Savory et al. } \\
(1996)\end{array}$ & Ross 1 / 2-10 wk & $\begin{array}{l}\text { VC, } 2 \text { XVC niveau, } A L, \\
\text { Verschillende ingrediënten } \\
\text { (o.a. } \mathrm{OH}, \mathrm{CaP})\end{array}$ & $2-6,6-10 w k$ & Algemeen gedrag & $\begin{array}{l}\text { AL: meer eten, zitten. Minder drinken, staan, } \\
\text { preening, objectpikken }\end{array}$ \\
\hline $\begin{array}{l}\text { Savory en Mann } \\
(1999)\end{array}$ & $\begin{array}{l}\text { Ross } 308 \text { (indiv) / 8- } \\
14 \text { wk }\end{array}$ & \begin{tabular}{|l|} 
Tweemaal per dag voeren \\
en verschillende voerporties
\end{tabular} & $8,14 \mathrm{wk}$ & Algemeen gedrag & $\begin{array}{l}\text { Grotere voerporties gaf meer stereotiep pikken na } \\
\text { voeropname. Staan nam af. }\end{array}$ \\
\hline $\begin{array}{l}\text { Hocking et al. } \\
(2001)\end{array}$ & Ross 308 / 1-24 wk & $\begin{array}{l}\text { VC, aangepast VC en AL } \\
\text { Hoog en laag eiwit }\end{array}$ & $6,12,18,24 \mathrm{wk}$ & Algemeen gedrag & $\begin{array}{l}\text { AL: meer rusten en minder foerageren, drinken en } \\
\text { objectpikken }\end{array}$ \\
\hline
\end{tabular}




\begin{tabular}{|c|c|c|c|c|c|}
\hline Referentie & Merk en periode & Behandelingen & Leeftijd metingen & Test & Effect \\
\hline \multirow[t]{4}{*}{$\begin{array}{l}\text { De Jong et al. } \\
(2002)\end{array}$} & Hybro / 3-12 wk & VC of $A L$ & $3,6,9 \mathrm{wk}$ & $\begin{array}{l}\text { Algemeen gedrag via } \\
\text { scan-sampling }\end{array}$ & $\begin{array}{l}\text { Alle leeftijden VC meer pikken naar (lege) voergoot, } \\
\text { lopen en scharrelen en minder zitgedrag. Op } 3 \text { en } 6 \\
\text { wk leeftijd VC meer drinken. Op } 6 \text { en } 9 \text { wk brachten } \\
\text { VC staan. Op } 9 \text { wk leeftijd VC minder comfortgedrag. } \\
\text { Geen verschil pikken naar objecten en dieren. }\end{array}$ \\
\hline & & & 7, $10 \mathrm{wk}$ & Lichaamstemperatuur & $\begin{array}{l}\text { AL hadden vs. VC in de donderperiode een hogere } \\
\text { lichaamstemperatuur. Tijdens de lichtperiode geen } \\
\text { verschillen. }\end{array}$ \\
\hline & & & $7,10 \mathrm{wk}$ & Hartslag & $\begin{array}{l}\text { AL hadden vs. VC een hogere hartslag tijdens de licht- } \\
\text { en donkerperiode. }\end{array}$ \\
\hline & & & 7, $10 \mathrm{wk}$ & Activiteit & $\begin{array}{l}\text { AL hadden vs. VC een lager activiteitsniveau tijdens } \\
\text { de licht- en donkerperiode. }\end{array}$ \\
\hline \multirow[t]{3}{*}{$\begin{array}{l}\text { de Jong et al. } \\
(2003)\end{array}$} & $\begin{array}{l}\text { Hybro en JA57 / 3-8 } \\
\text { wk }\end{array}$ & $\begin{array}{l}\text { Hybro: } 90,70,50,35 \text { en } \\
\text { 25\% van ad libitum (AL) } \\
\text { opname en AL. } \\
\text { JA57: } 70 \% \text { van AL en AL }\end{array}$ & $7 \mathrm{wk}$ & $\begin{array}{l}\text { Algemeen gedrag via } \\
\text { scan-sampling }\end{array}$ & $\begin{array}{l}\text { Hybro: } \\
\text { Bij } 50 \text { en } 70 \% \text { voerniveau van } A L \text { minder staan. Dus } \\
\text { meer staan bij } 25,35,90 \% \text { van } A L \text { en } A L \text {. } \\
\text { Meest zitten bij } 70 \% \text { van } A L \text {, minst bij } 25 \% \text { van } A L \text {. } \\
\text { Geen effecten op ander gedrag. Objectpikken was te } \\
\text { laag voor een betrouwbare analyse. } \\
\text { JA57: } \\
\text { AL dieren besteden meer tijd aan foerageren dan de } \\
70 \% \text { van } A L \text {. }\end{array}$ \\
\hline & & & $6 \mathrm{wk}$ & Open-field test & $\begin{array}{l}\text { Hybro: Meer lopen bij } 25,35,50 \text { en } 70 \% \text { van } A L \text { vs. } \\
90 \% \text { van AL en AL. } \\
\text { Minder inactief bij meer VC. }\end{array}$ \\
\hline & & & $8 w k$ & FIM test & $\begin{array}{l}\text { De relatieve voeropname was het hoogst voor de } \\
\text { dieren met de hoogste VC ( } 35 \% \text { en } 25 \% \text { van AL). } \\
\text { Lineair verband tussen het niveau van VC en } \\
\text { voeropname: meer voer bij meer VC. } \\
\text { Verder meer pikken naar voer en minder } \\
\text { verzorgingsgedrag bij toenemende VC. }\end{array}$ \\
\hline
\end{tabular}




\begin{tabular}{|c|c|c|c|c|c|}
\hline Referentie & Merk en periode & Behandelingen & Leeftijd metingen & Test & Effect \\
\hline $\begin{array}{l}\text { Van der Haar en } \\
\text { van Voorst (2001) }\end{array}$ & Cobb 500 / 4-24 wk & $\begin{array}{l}\text { Twee- vs. eenmaal per dag } \\
\text { voer verstrekken }\end{array}$ & $11-13,17-19 w k$ & Gedragswaarnemingen & $\begin{array}{l}\text { 2x voeren: minder objectpikken, scharrelen } \\
\text { (ochtend), zitten en meer staan (ochtend). }\end{array}$ \\
\hline $\begin{array}{l}\text { De Jong et al. } \\
\text { (2002) }\end{array}$ & Hybro / 3- 12 wk & VC vs. AL & $3,6,9 \mathrm{wk}$ & Voeropname tijd & VC: binnen 30 minuten voer op. \\
\hline \multirow[t]{2}{*}{$\begin{array}{l}\text { De Jong et al. } \\
(2005 a)\end{array}$} & Hybro G / 2-8 wk & $\begin{array}{l}\text { Tweemaal daags voeren en } \\
\text { voer op strooisel }\end{array}$ & $7 \mathrm{wk}$ & Gedrags-waarnemingen & $\begin{array}{l}\text { Voer op strooisel gaf minder objectpikken. } \\
\text { Tweemaal per dag voeren gaf meer lopen. }\end{array}$ \\
\hline & & & $8 \mathrm{wk}$ & FIM test & Geen effecten \\
\hline \multirow[t]{3}{*}{$\begin{array}{l}\text { De Jong et al. } \\
(2005 b)\end{array}$} & Cobb 500 / 4-24 wk & $\begin{array}{l}\text { Laag energetische voeders } \\
(-12 \% \text { en }-23 \%) \text { en } A L\end{array}$ & $\begin{array}{l}6,10,16,20,26,40 \\
\text { wk }\end{array}$ & $\begin{array}{l}\text { Algemeen gedrag via } \\
\text { scan-sampling }\end{array}$ & $\begin{array}{l}\text { Minder objectpikken en meer zitten met }-23 \% \text { voer op } \\
6 \text { en } 10 \text { wk leeftijd. } \\
\text { Meer voer opnemen bij verdund voer. Minder zitten, } \\
\text { comfort en foerageren bij }-23 \% \text { voer tijdens leg. }\end{array}$ \\
\hline & & & $10 \mathrm{wk}$ & FIM test & $\begin{array}{l}\text { Laagste compenserende voeropname voor de dieren } \\
\text { op }-23 \% \text { voer. }\end{array}$ \\
\hline & & & $\begin{array}{l}\text { Opfok: } 6,10,13,16 \\
20 \mathrm{wk} \\
\text { Leg: } 26,30,40,60 \mathrm{wk}\end{array}$ & Voeropname tijd & $\begin{array}{l}\text { Opfok: } \\
-12 \% \text { voer: }+41 \% \text { langer tijd } \\
-23 \% \text { voer: }+109 \% \text { langer tijd } \\
\text { Leg: } \\
-12 \% \text { voer: }+65 \% \text { langer tijd } \\
-23 \% \text { voer: }+134 \% \text { langer tijd }\end{array}$ \\
\hline \multirow[t]{2}{*}{$\begin{array}{l}\text { Sandilands et al. } \\
(2005)\end{array}$} & Ross 308 / 1-44 wk & $\begin{array}{l}\text { VC, AL voer met CaP } \\
\text { (calciumpropionaat) }{ }^{1} \text { en } \\
\text { haverdoppen }\end{array}$ & $5,11,19,34,44 \mathrm{wk}$ & $\begin{array}{l}\text { Algemeen gedrag via } \\
\text { scan-sampling }\end{array}$ & $\begin{array}{l}\text { Minder eet- en drinkgedrag en meer objectpikken (tot } \\
50 \% \text { ). } \\
\text { Effecten weg tijdens legperiode. }\end{array}$ \\
\hline & & 2 voeders & $15,34,43 \mathrm{wk}$ & Feeding motivation & VC dieren aten meer tijdens alle leeftijden. \\
\hline
\end{tabular}




\begin{tabular}{|c|c|c|c|c|c|}
\hline Referentie & Merk en periode & Behandelingen & Leeftijd metingen & Test & Effect \\
\hline \multirow[t]{2}{*}{$\begin{array}{l}\text { Sandilands et al. } \\
(2006)\end{array}$} & Ross 308 / 1-20 wk & $\begin{array}{l}\text { VC, AL voer met } \\
\text { verschillende doseringen } \\
\text { CaP en haverdoppen }\end{array}$ & $6,12,18 \mathrm{wk}$ & $\begin{array}{l}\text { Algemeen gedrag via } \\
\text { scan-sampling }\end{array}$ & $\begin{array}{l}\text { VC dieren vertoonden } 47-54 \% \text { objectpikken vs. } 1 \% \\
\text { andere behandelingen. } \\
\text { Op stofbaden na verschilden alle behandelingen qua } \\
\text { gedrag. }\end{array}$ \\
\hline & & 6 voeders & $5-6,11-12,17-18 w k$ & Feeding motivation & VC dieren aten meer tijdens alle leeftijden. \\
\hline \multirow[t]{2}{*}{$\begin{array}{l}\text { Nielsen et al. } \\
(2011)\end{array}$} & Ross 308 / 3-16 wk & $\begin{array}{l}\text { Controlevoer }(80 \% \\
\text { onoplosbaar vezel=OOV), } \\
2 x \text { vezel } 89 \% \text { OOV en } 2 x \\
\text { vezel } 71 \% \text { OOV }\end{array}$ & 7 wk & Novel feed test & $\begin{array}{l}\text { Meer staart pikken/likken en stereotiep objectpikken } \\
\text { (tweemaal hoger) bij controlevoer }\end{array}$ \\
\hline & & & $10,5-14,5$ wk & The Feeding Rate test & $\begin{array}{l}\text { VC dieren eten sneller en een hogere compensatoire } \\
\text { voeropname }\end{array}$ \\
\hline $\begin{array}{l}\text { Buckley et al. } \\
(2011)\end{array}$ & Ross 308 / 2-10 wk & VC, $40 \%, 80 \%, A L$ & $7-10 \mathrm{wk}$ & Y-maze test & $\begin{array}{l}\text { De Y-maze test is niet de meest geschikte methode } \\
\text { om de voorkeur van voercontrole dieren te testen. }\end{array}$ \\
\hline Dixon et al. (2014) & Ross $308 / 5-11 \mathrm{wk}$ & $\begin{array}{l}\mathrm{VC}, 2 \times \mathrm{VC} \text { niveau en } 3 \times \mathrm{VC} \\
\text { niveau }\end{array}$ & $\begin{array}{l}\text { Training: } 6 \mathrm{wk} \\
\text { Testen: } 7-10 \mathrm{wk}\end{array}$ & $\begin{array}{l}\text { Water barrière oversteken } \\
\text { voor voer }\end{array}$ & $\begin{array}{l}\text { VC dieren staken vaker de barrière over voor voer, } \\
\text { hadden daar minder voor nodig en foerageerden } \\
\text { meer. }\end{array}$ \\
\hline \multirow[t]{2}{*}{$\begin{array}{l}\text { Van Emous et al. } \\
(2014)\end{array}$} & Ross 308 / 3-40 wk & $\begin{array}{l}\text { Hoog, midden en laag eiwit } \\
\text { gehalte opfok en hoog en } \\
\text { laag gewicht opfokperiode }\end{array}$ & $7,12,17,22,27 \mathrm{wk}$ & $\begin{array}{l}\text { Algemeen gedrag via } \\
\text { scan-sampling }\end{array}$ & $\begin{array}{l}\text { Midden en laag RE: meer eetgedrag, zitstok, staan, } \\
\text { zitten en minder objectpikken en pikken naar anderen } \\
\text { tijdens opfokperiode. } \\
\text { Hoger opfokgewicht: meer eet- en zitgedrag. }\end{array}$ \\
\hline & & & $7,12,17 \mathrm{wk}$ & Voeropname tijd & 22 en $63 \%$ langere eettijd voor midden en laag RE \\
\hline $\begin{array}{l}\text { Morrissey et al. } \\
\text { (2014b) }\end{array}$ & Ross $708 / 4-37 \mathrm{wk}$ & $\begin{array}{l}3 \text { voeders (controle, } \\
\text { Sojahullen+CaP in } 2 \\
\text { vormen) i.c.m. } \\
\text { ED en SAD }\end{array}$ & $\begin{array}{l}11,13,15,17,19,25 \\
29 \mathrm{wk}\end{array}$ & $\begin{array}{l}\text { Algemeen gedrag via } \\
\text { scan-sampling }\end{array}$ & $\begin{array}{l}\text { Vezelrijke voeders gaf meer rusten minder } \\
\text { verenpikken, objectpikken en agressie tijden } \\
\text { opfokperiode. Geen verschil in de legperiode. }\end{array}$ \\
\hline
\end{tabular}




\begin{tabular}{|c|c|c|c|c|c|}
\hline Referentie & Merk en periode & Behandelingen & Leeftijd metingen & Test & Effect \\
\hline $\begin{array}{l}\text { Buckley et al. } \\
\text { (2015) }\end{array}$ & $\begin{array}{l}\text { Ross } 308 \\
\text { (vleeskuikens) / 4- } \\
10 \mathrm{wk}\end{array}$ & $\mathrm{VC}, \mathrm{AL}$ & $10 \mathrm{wk}$ & $\begin{array}{l}\text { State-dependent learning } \\
\text { (SDL) }\end{array}$ & Geen goede methode om honger bij vkod te meten. \\
\hline \multirow[t]{2}{*}{$\begin{array}{l}\text { van Emous et al. } \\
(2015 a)\end{array}$} & Ross 308 / 0-60 wk & $\begin{array}{l}\text { Hoog en laag eiwit gehalte } \\
\text { voer opfok }\end{array}$ & $\begin{array}{l}11,17,27,38,46,54 \\
\text { wk }\end{array}$ & $\begin{array}{l}\text { Algemeen gedrag via } \\
\text { scan-sampling }\end{array}$ & $\begin{array}{l}\text { Meer eetgedrag, zitten en comfort gedrag en minder } \\
\text { lopen, foerageren en objectpikken tijdens } \\
\text { opfokperiode. } \\
\text { Geen effecten legperiode }\end{array}$ \\
\hline & & & $\begin{array}{l}11,17,27,38,48,54 \\
\text { wk }\end{array}$ & Voeropname tijd & $\begin{array}{l}\text { Laag eiwit voer: ruim tweemaal langere eettijd } \\
\text { Geen effect legperiode }\end{array}$ \\
\hline \multirow[t]{3}{*}{$\begin{array}{l}\text { De Los Mozos et al. } \\
\text { (2017) }\end{array}$} & Ross 308 / 3-19 wk & $\begin{array}{l}\text { Controle }+15 \% \text { verdund } \\
\text { voer } \\
\text { Controle en } 15 \% \text { hoger } \\
\text { gewicht }\end{array}$ & $9,15 \mathrm{wk}$ & $\begin{array}{l}\text { Algemeen gedrag via } \\
\text { scan-sampling }\end{array}$ & Geen effect van behandelingen \\
\hline & & & $11 \mathrm{wk}$ & The Feeding Rate test & $\begin{array}{l}\text { Verdund voer gaf } 30 \% \text { lagere voeropname vs. } \\
\text { controle voer tijdens AL voeren }\end{array}$ \\
\hline & & & 7, 11, $19 \mathrm{wk}$ & Voeropnametijd & $\begin{array}{l}\text { Verdund voer: }+4,6 \% \\
\text { Hoger opfokgewicht: }+10,5 \%\end{array}$ \\
\hline \multirow[t]{2}{*}{$\begin{array}{l}\text { Arrazola et al. } \\
\text { (2019) }\end{array}$} & Ross 308 / 3-22 wk & $\begin{array}{l}\text { Controle voer, alternatief } \\
\text { (soja hullen }+ \text { CaP), } 4 / 3 \\
\text { schema en verschillende } \\
\text { voerprogramma's }\end{array}$ & $7,10,14,18 \mathrm{wk}$ & $\begin{array}{l}\text { Algemeen gedrag via } \\
\text { scan-sampling }\end{array}$ & $\begin{array}{l}\text { Dieren controlevoer actiever dan de andere drie } \\
\text { behandelingen }(P<0,001) \\
\text { Dieren alternatieve voer meer inactief dan } \\
\text { controlevoer. } \\
\text { Alternatief voer: minder stereotiep gedrag tijdens } \\
\text { vroege opfok vs. controlevoer }\end{array}$ \\
\hline & & & $4,8,12,16,20 \mathrm{wk}$ & Feed intake test & Controlevoer: hogere motivatie om voer op te nemen \\
\hline
\end{tabular}




\begin{tabular}{|l|l|l|l|l|l|}
\hline Referentie & Merk en periode & Behandelingen & Leeftijd metingen & Test & Effect \\
\hline $\begin{array}{l}\text { Riber en Tahamtani } \\
(2020)\end{array}$ & Ross 308 / 1-19 wk & $\begin{array}{l}\text { Controle, onoplosbare vezel } \\
\text { (haverdoppen), mix } \\
\text { onoplosbare (haverdoppen) } \\
+ \text { oplosbare vezels } \\
\text { (bietenpulp), snijmais }\end{array}$ & $8-9,17-18 \mathrm{wk}$ & Feeding rate & Geen effect \\
\hline & & $8-9,17-18 \mathrm{wk}$ & Frustratie test & $\begin{array}{l}\text { Onoplosbare vezels en mix vezels voer: minder } \\
\text { veranderingen in activiteit }=\text { lagere voermotivatie }\end{array}$ \\
\hline & & $8-9,17-18 \mathrm{wk}$ & Feed intake test & $\begin{array}{l}\text { Onoplosbaar vezels voer lagere compensatie } \\
\text { voeropname }\end{array}$ \\
\hline & & $12-13 \mathrm{wk}$ & $\begin{array}{l}\text { Motivatie toegang vers } \\
\text { strooisel }\end{array}$ & Mix geeft minder motivatie voor vers strooisel \\
\hline $\begin{array}{l}\text { van Emous et al. } \\
(2020)\end{array}$ & Ross 308 / 0-40 wk & $\begin{array}{l}\text { Twee- vs. eenmaal per dag } \\
\text { voer } \\
\text { Verdund vs. controle voer }\end{array}$ & $\begin{array}{l}5,10,15,20,30,40 \\
\text { wk }\end{array}$ & $\begin{array}{l}\text { Algemeen gedrag via } \\
\text { scan-sampling }\end{array}$ & $\begin{array}{l}\text { Tweemaal daags voeren heeft meer effecten op } \\
\text { gedrag dan verdund voer. Het geeft echter geen } \\
\text { significante verbetering van het welzijn. }\end{array}$ \\
\hline
\end{tabular}

${ }^{1}$ Operant conditioning: motivatie om voer op te nemen test.

${ }^{2}$ FIM test $=$ Feed Intake Motivation test. Onbeperkt voer verstrekken gedurende enige dagen. 


\section{Bijlage 3 Overzicht literatuur effecten voercontrole op productie}

\begin{tabular}{|c|c|c|c|c|c|}
\hline Referentie & Merk en periode & Behandelingen & Leeftijd metingen & Test & Effect \\
\hline \multirow[t]{3}{*}{$\begin{array}{l}\text { Katanbaf et al. } \\
\text { (1989) }\end{array}$} & NA / 0-65 wk & VC vs. AL & $0-65 w k$ & Voeropname & $\begin{array}{l}\text { AL: max } 220 \mathrm{~g} \text { op } 20 \text { wk, daalt daarna snel naar } 150 \\
\text { g op } 35 \text { wk en daarna langzaam dalend naar } 120 \mathrm{~g} \text { op } \\
50 \mathrm{wk} \\
\text { VC: schema fokkerijorganisatie. Op } 23 \text { wk AL: } 140 \\
\text { gram maximaal }\end{array}$ \\
\hline & & & $\begin{array}{l}1-23 \text { wk ( } 2 \text { wk) } \\
24-29 \text { (week) } \\
30-66 \text { wk ( } 2 \text { of } 4 \text { wk) }\end{array}$ & Lichaamsgewicht & $\begin{array}{l}\text { AL: lineair stijging tussen } 1 \text { en } 18 \text { wk naar max. ca. } \\
4.600 \mathrm{~g} \\
\text { VC: naar max } 3500 \text { gram einde legperiode }\end{array}$ \\
\hline & & & Wekelijks & Uitval & $\begin{array}{l}\text { VC vs. AL (einde opfok): } 0 \text { vs. } 8 \% \\
\text { VC vs. AL (einde leg): ca. } 14 \text { vs. } 70 \% \text { ( } 50 \% \text { op } 52 \\
\text { weken) }\end{array}$ \\
\hline \multirow[t]{4}{*}{$\begin{array}{l}\text { Savory et al. } \\
(1993)\end{array}$} & Ross 1 / 2-21 wk & $\mathrm{VC}, 2 \times \mathrm{VC}$ niveau en $\mathrm{AL}$ & $2-21 w k$ & Groei & $2 x V C$ en $A L$ ruwweg $2 x$ en $3 x$ hogere groei dan VC \\
\hline & & & $2-21 w k$ & Voeropname & $\begin{array}{l}\text { Norm: } 2 \text { wk } 44 \% \text { van } A L \text {, tussen } 7 \text { en } 15 \text { wk } 25 \% \text { en } \\
51 \% \text { in wk } 21 . \\
\text { Echter: gemiddeld } 45 \% \text { vs. AL bij gelijk } \\
\text { lichaamsgewicht }\end{array}$ \\
\hline & & & 2-21 wk & Water opname & Nat strooisel (14 uur licht en open water) \\
\hline & & & 2-21 wk & Uitval & AL vs. VC en $2 \times$ VC: 20 vs. $10 \%$ en $0 \%$ \\
\hline $\begin{array}{l}\text { Hocking et al. } \\
\text { (1996) }\end{array}$ & Ross $1 / 1-18$ wk & $\begin{array}{l}\text { VC, } A L, 25,40,55,70 \text { en } \\
85 \% \text { van ad lib }\end{array}$ & $6,12,18 \mathrm{wk}$ & Water opname & Hoger bij (ml/kg BW) bij lager gewicht \\
\hline
\end{tabular}




\begin{tabular}{|c|c|c|c|c|c|}
\hline Referentie & Merk en periode & Behandelingen & Leeftijd metingen & Test & Effect \\
\hline \multirow[t]{3}{*}{$\begin{array}{l}\text { Van der Haar en } \\
\text { van Voorst (2001) }\end{array}$} & Cobb 500 / 4-24 wk & $\begin{array}{l}\text { Twee- vs. eenmaal per dag } \\
\text { voer verstrekken }\end{array}$ & $0-19 w k$ & Uitval & $\begin{array}{l}2 x \text { vs. } 1 x \text { voeren: } 5,2 \text { vs. } 3,0 \% \text { (tendens): interactie } \\
\text { met voersysteem (voerpannen-spinfeeder) }\end{array}$ \\
\hline & & & $13,19 \mathrm{wk}$ & Uniformiteit & $\begin{array}{l}2 x \text { vs. } 1 \text { x voeren: } 83,5 \text { vs. } 90,2 \% \text { op } 13 \text { weken } \\
\text { Geen verschil op } 19 \text { weken }\end{array}$ \\
\hline & & & $0-19 w k$ & Voergift & $2 x$ vs. $1 x$ voeren: 7810 vs. 7509 gram \\
\hline $\begin{array}{l}\text { Hocking et al. } \\
(2001)\end{array}$ & Ross 308 / 1-24 wk & $\begin{array}{l}\text { VC, aangepast VC en AL } \\
\text { Hoog en laag eiwit }\end{array}$ & $6,12,18,24 \mathrm{wk}$ & Water opname & Lager bij (ml/kg BW) bij AL \\
\hline \multirow[t]{7}{*}{ Heck et al. (2004) } & $\begin{array}{l}\text { Standaard en dwerg } \\
\text { Hubbard / } 1^{\mathrm{e}} 0-40 \\
\text { wk / 2 } 0-50 \text { wk }\end{array}$ & $\begin{array}{l}\text { VC vs. AL (Hubbard), } \\
\text { dwerg: AL }\end{array}$ & $\begin{array}{l}2,5,8,11,14,17,20 \\
\text { wk } \\
23,26,29,32,35,38 \\
40 w k\end{array}$ & Voergift opfok- legperiode & $\begin{array}{l}\text { Experiment 1: } \\
\text { VC vs. AL (opfok): ca. } 55 \text { vs. } 150 \mathrm{gram} / \mathrm{d} / \mathrm{d} \\
\text { VC vs. AL (leg): } 167 \text { vs. } 184 \mathrm{gram} / \mathrm{d} / \mathrm{d} \\
\text { Experiment 2: } \\
\text { VC vs. AL (opfok): ca. } 55 \text { vs. } 150 \mathrm{gram} / \mathrm{d} / \mathrm{d} \\
\text { VC vs. AL (leg): } 162 \text { vs. } 210 \mathrm{gram} / \mathrm{d} / \mathrm{d}\end{array}$ \\
\hline & & & $\begin{array}{l}\operatorname{Exp} 1: 1,3,6,9,12 \\
15,18,21,24,27,30 \\
33,36,39 \mathrm{wk} \\
\operatorname{Exp} 2: 3,6,9,12,15 \\
18,22,25,30,35 \mathrm{wk}\end{array}$ & Lichaamsgewicht & $\begin{array}{l}\text { Exp 1: } \\
\text { VC vs. AL }(21 \mathrm{wk}): \text { ca. } 2,2 \text { vs. } 5,0 \mathrm{~kg} \\
\text { VC vs. AL }(39 \mathrm{wk}): \text { ca. } 3,9 \text { vs. } 5,6 \mathrm{~kg} \\
\text { Exp } 2: \\
\text { VC vs. } A L(22 \mathrm{wk}): \text { ca. } 2,45 \text { vs. } 5,3 \mathrm{~kg} \\
\text { VC vs. AL }(35 \mathrm{wk}): 3,63 \text { vs. } 5,34 \mathrm{~kg}\end{array}$ \\
\hline & & & 21 tot $40 / 50 \mathrm{wk}$ & Uitval & $\begin{array}{l}\text { Exp 1: VC vs. AL (opfok+leg 0-31wk): } 0 \text { vs. } 7,5 \% \\
\text { Exp 1: VC vs. AL (leg } 32-40): 6,1 \text { vs. } 31,1 \% \\
\text { Exp 1: VC vs. AL (totaal } 40 \text { wk): } 6,1 \text { vs. } 38,6 \% \\
\text { Exp 2: VC vs. AL ( } 50 \text { wk): } 5,6 \text { vs. } 40,4 \%\end{array}$ \\
\hline & & & $\begin{array}{l}\text { Iedere week 20-40 wk } \\
\text { (gem } 4 \mathrm{~d} \text { ) }\end{array}$ & Eigewicht & $\begin{array}{l}\text { Exp 1: VC vs. AL: } 63,7 \text { vs. } 63,7 \mathrm{~g} \\
\text { Exp 2: VC vs. AL: } 65,6 \text { vs. } 65,2 \mathrm{~g} \text { (NS) }\end{array}$ \\
\hline & & & Iedere dag 20- $50 \mathrm{wk}$ & Leg\% & $\begin{array}{l}\text { Exp 1: VC vs. AL: } 79,1 \text { vs. } 52,4 \% \\
\text { Exp 2: VC vs. AL: } 73,2 \text { vs. } 22,5 \%\end{array}$ \\
\hline & & & & Voederconversie & $\begin{array}{l}\operatorname{Exp} 1: \text { VC vs. AL: } 3,33 \text { vs. } 5,80 \\
\text { Exp 2: VC vs. AL: } 3,44 \text { vs. } 14,51\end{array}$ \\
\hline & & & & Tijdstip in productie & VC vs. AL: 6 weken later \\
\hline
\end{tabular}




\begin{tabular}{|c|c|c|c|c|c|}
\hline Referentie & Merk en periode & Behandelingen & Leeftijd metingen & Test & Effect \\
\hline & & & $20-40$ of $20-50 \mathrm{wk}$ & $\begin{array}{l}1^{\mathrm{e}} \text { soort eieren } \\
\text { Dubbeldooiers } \\
\text { Windeieren } \\
\text { Breukeieren } \\
\text { Vuile eieren }\end{array}$ & $\begin{array}{l}\operatorname{Exp} 1: 96,0 \text { vs. } 78,4 \% \\
\operatorname{Exp} 2: 96,5 \text { vs. } 88,9 \% \\
\operatorname{Exp} 1: 2,5 \text { vs. } 7,6 \% \\
\operatorname{Exp} 2: 0,4 \text { vs. } 2,2 \% \\
\operatorname{Exp} 1: 0,4 \text { vs. } 2,4 \% \\
\operatorname{Exp} 2: 2,0 \text { vs. } 6,3 \% \\
\operatorname{Exp} 1: 3,2 \text { vs. } 5,2 \% \\
\operatorname{Exp} 2: 1,1 \text { vs. } 2,5 \%(\mathrm{NS}) \\
\operatorname{Exp} 1: 11,8 \text { vs. } 9,5 \%(\mathrm{NS})\end{array}$ \\
\hline & & & $32 \mathrm{wk}$ & Follikels/ovarium (\#) & 8,0 vs. 9,4 \\
\hline \multirow[t]{6}{*}{$\begin{array}{l}\text { Tolkamp et al } \\
(2005)\end{array}$} & Ross $308 / 1-45 \mathrm{wk}$ & $\begin{array}{l}\text { VC vs. } \mathrm{AL}+\mathrm{CaP} \text { en } \\
\mathrm{AL}+\mathrm{CaP}+\mathrm{OH}\end{array}$ & $1-20 \mathrm{wk}$ & Voeropname & $\begin{array}{l}A L+\mathrm{CaP} \text { uit de proef genomen op } 12 w k \\
80 \% \text { hogere voeropname } \mathrm{AL}+\mathrm{CaP}+\mathrm{OH} \text { vs. } \mathrm{VC}\end{array}$ \\
\hline & & & $6,12,20,35,45 \mathrm{wk}$ & Uniformiteit & Geen effect \\
\hline & & & $1-45 \mathrm{wk}$ & Diergewicht & Geen effect op diergewicht opfok en legperiode \\
\hline & & & $20-45 w k$ & Productie & Geen effect \\
\hline & & & & Eigewicht & Geen effect \\
\hline & & & & Broedeikwaliteit & Geen effect \\
\hline $\begin{array}{l}\text { De Jong et al. } \\
(2005 b)\end{array}$ & Cobb $500 / 0-60 \mathrm{wk}$ & $\begin{array}{l}\text { Laag energetische voeders } \\
(-12 \% \text { en }-23 \%)\end{array}$ & $\begin{array}{l}\text { Opfok: } 6,10,13,16 \\
20 \mathrm{wk} \\
\text { Leg: } 26,30,40,60 \mathrm{wk}\end{array}$ & Voeropname & $\begin{array}{l}\text { Opfok: } \\
-12 \% \text { voer: }+13 \% \text { voer } \\
-23 \% \text { voer: }+25 \% \text { voer } \\
\text { Leg: } \\
-12 \% \text { voer: }+13 \% \text { voer } \\
-23 \% \text { voer: }+28 \% \text { voer }\end{array}$ \\
\hline \multirow[t]{2}{*}{$\begin{array}{l}\text { Sandilands et al. } \\
(2005)\end{array}$} & Ross 308 / 1-44 wk & VC, AL voer met $\mathrm{CaP}$ en $\mathrm{OH}$ & $1,6,12,20 \mathrm{wk}$ & Diergewicht & Na 18 wk $\mathrm{CaP}+\mathrm{OH}$ voeders hoger gewicht \\
\hline & & 2 voeders & $1,6,12,20 \mathrm{wk}$ & Uniformiteit & Geen effect \\
\hline
\end{tabular}




\begin{tabular}{|c|c|c|c|c|c|}
\hline Referentie & Merk en periode & Behandelingen & Leeftijd metingen & Test & Effect \\
\hline \multirow[t]{2}{*}{$\begin{array}{l}\text { Sandilands et al. } \\
\text { (2006) }\end{array}$} & Ross 308 / 1-20 wk & $\begin{array}{l}\mathrm{VC}, \mathrm{AL} \text { voer met } \\
\text { verschillende doseringen } \\
\mathrm{CaP} \text { en } \mathrm{OH}\end{array}$ & $1,6,12,20 \mathrm{wk}$ & Diergewicht & $\begin{array}{l}\text { Op } 6 \text { en } 12 \text { wk } 1 \text { behandeling hoger en } 1 \text { beh lager. } \\
\text { Op } 20 \text { wk geen verschillen }\end{array}$ \\
\hline & & 6 voeders & $1,6,12,20 \mathrm{wk}$ & Uniformiteit & $\begin{array}{l}\text { Voeders met haverdoppen slechtste uniformiteit op } 6 \\
\text { en } 12 \mathrm{wk} \text {. }\end{array}$ \\
\hline \multirow[t]{2}{*}{$\begin{array}{l}\text { Enting et al. } \\
(2007 a)\end{array}$} & Cobb $500 / 0-60$ wk & $\begin{array}{l}\text { Laag energetische voeders } \\
(-12 \% \text { en }-23 \%)\end{array}$ & $6,12,18,22,26 \mathrm{wk}$ & Diergewicht & Op 22 en 26 wk lager gewicht voor LD12OP groep \\
\hline & & & $6,12,18,22,26 \mathrm{wk}$ & Voeropname & $-12 \%$ groep: $+11 \%$ voer en $-23 \%$ groep: $+25 \%$ voer \\
\hline \multirow[t]{3}{*}{$\begin{array}{l}\text { Enting et al. } \\
(2007 \mathrm{~b})\end{array}$} & $\begin{array}{l}\text { Cobb } 500 / 20-60 \text { wk } \\
\text { (leg) }\end{array}$ & $\begin{array}{l}\text { Laag energetische voeders } \\
(-11 \% \text { en }-21 \%)\end{array}$ & Legperiode & Eiproductie & $-11 \%$ groep: hogere eiproductie \\
\hline & & & Wekelijks & Eigewicht & Hoger voor de laag energetische voeders \\
\hline & & & & Broederij & $\begin{array}{l}\text { Geen verschil in bevruchting } \\
\text { LD11OP: lagere uitkomst }\end{array}$ \\
\hline \multirow[t]{5}{*}{$\begin{array}{l}\text { Van Emous et al. } \\
(2014)\end{array}$} & Ross 308 / 3-40 wk & $\begin{array}{l}\text { Hoog, midden en laag eiwit } \\
\text { gehalte voer opfok en hoog } \\
\text { en laag opfokgewicht }\end{array}$ & $7,12,17 \mathrm{wk}$ & Voeropname & 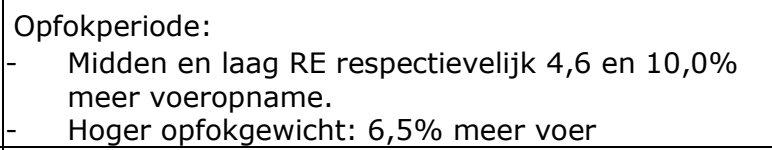 \\
\hline & & & $5,10,15,20 \mathrm{wk}$ & Uniformiteit & Geen effect van RE\% en opfokgewicht \\
\hline & & & $23-40 w k$ & Eiproductie & Geen effect van RE\% en opfokgewicht \\
\hline & & & $23-40 w k$ & Broederij & $\begin{array}{l}\text { Hogere bevruchting, uitkomst bevruchte eieren en } \\
\text { lagere embryonale sterfte bij hoog opfokgewicht }\end{array}$ \\
\hline & & & $\begin{array}{l}6,11,16,20,25,30 \\
35,40 \mathrm{wk}\end{array}$ & Bevedering & $\begin{array}{l}\text { Slechter bevedering midden en laag RE tot en met } 11 \\
\text { wk }\end{array}$ \\
\hline
\end{tabular}




\begin{tabular}{|c|c|c|c|c|c|}
\hline Referentie & Merk en periode & Behandelingen & Leeftijd metingen & Test & Effect \\
\hline $\begin{array}{l}\text { Morrissey et al. } \\
(2014 b)\end{array}$ & Ross 708 / 4-37 wk & $\begin{array}{l}3 \text { voeders (controle, } \\
\text { Sojahullen+CaP in } 2 \\
\text { vormen) i.c.m. } \\
\text { ED en SAD }\end{array}$ & $10,14,20,26,36 \mathrm{wk}$ & Bevedering & Vanaf 14 wk bevedering slechter bij controlevoer. \\
\hline \multirow[t]{4}{*}{$\begin{array}{l}\text { Van Emous et al. } \\
(2015 b)\end{array}$} & Ross 308 / 3-60 wk & $\begin{array}{l}\text { Hoog en laag eiwit gehalte } \\
\text { voer opfok }\end{array}$ & $2-60 w k$ & Voeropname & Laag eiwit voer: $12,8 \%$ meer voer \\
\hline & & & $23-60 \mathrm{wk}$ & Eiproductie & $\begin{array}{l}\text { Meer eieren } 2^{\mathrm{e}} \text { helft legperiode bij laag eiwit voer } \\
\text { opfok }\end{array}$ \\
\hline & & & & Broederij & $\begin{array}{l}\text { Hogere uitkomst van bevruchte en ingelegde eieren } 1^{\mathrm{e}} \\
\text { helft legperiode door lagere embryonale sterfte }\end{array}$ \\
\hline & & & $\begin{array}{l}5,10,15,20,30,40 \\
50,60 \mathrm{wk}\end{array}$ & Bevedering & Slechter tot 30 weken leeftijd bij laag eiwit voer \\
\hline \multirow[t]{2}{*}{$\begin{array}{l}\text { De Los Mozos et al. } \\
(2017)\end{array}$} & Ross 308 / 3-19 wk & $\begin{array}{l}\text { Controle en verdund voer } \\
(15 \%) \\
\text { Controle en } 15 \% \text { hoger } \\
\text { opfokgewicht }\end{array}$ & 3-19 wk & Voeropname & $\begin{array}{l}\text { Verdund voer: }+21 \% \text { voer } \\
\text { Hoger opfokgewicht: }+21 \% \text { voer }\end{array}$ \\
\hline & & & $19 \mathrm{wk}$ & Uniformiteit & Geen effect van beide behandelingen \\
\hline \multirow[t]{5}{*}{$\begin{array}{l}\text { Arrazola et al. } \\
(2019)\end{array}$} & Ross 308 / 3-22 wk & $\begin{array}{l}\text { Controle voer, alternatief } \\
\text { (soja hullen }+\mathrm{CaP}), 4 / 3 \\
\text { schema en verschillende } \\
\text { voerprogramma's }\end{array}$ & $3,5,7,11,17,22 \mathrm{wk}$ & Diergewicht & $\begin{array}{l}\text { Niet dagelijks groeiden bij dezelfde voergift minder } \\
\text { dan dagelijks gevoerde dieren. }\end{array}$ \\
\hline & & & $3,5,7,11,17,22 \mathrm{wk}$ & Uniformiteit & $\begin{array}{l}\text { Alternatief voer en verschillende programma's best CV } \\
\text { op } 22 \mathrm{wk}\end{array}$ \\
\hline & & & $5,11,18,21 \mathrm{wk}$ & Bevedering & Bevedering slechter bij controle voer \\
\hline & & & $15,21 \mathrm{wk}$ & Stress lijnen & Meer stress lijnen bij controle voer \\
\hline & & & $4-22 \mathrm{wk}$ & Strooisel kwaliteit & Tot en met 11 wk vochtiger strooisel alternatief voer \\
\hline
\end{tabular}




\begin{tabular}{|c|c|c|c|c|c|}
\hline & & & $5,11,18,21 \mathrm{wk}$ & $\begin{array}{l}\text { Voetzoollaesies, } \\
\text { brandhakken, huidkrassen }\end{array}$ & $\begin{array}{l}\text { Meer voetzoollaesies bij alternatief voer } \\
\text { Geen effect op brandhakken en huidkrassen }\end{array}$ \\
\hline Referentie & Merk en periode & Behandelingen & Leeftijd metingen & Test & Effect \\
\hline \multirow[t]{8}{*}{$\begin{array}{l}\text { van Emous en } \\
\text { Mens (2020) }\end{array}$} & Ross 308 /3-40 wk & $\begin{array}{l}\text { Twee- vs. eenmaal per dag } \\
\text { voer } \\
\text { Verdund vs. controle voer }\end{array}$ & Wekelijks & Diergewicht & Geen verschil i.v.m. volgen gewichtsnormen \\
\hline & & & $3-23 \mathrm{wk}$ & Voeropname & $17 \%$ hoger voeropname voor verdund voer \\
\hline & & & $10,20 \mathrm{wk}$ & Uniformiteit & $\begin{array}{l}\text { Tweemaal daags voer: betere uniformiteit op } 10 \mathrm{wk} \\
\text { Verdund voer: geen effect }\end{array}$ \\
\hline & & & $2-40 \mathrm{wk}$ & Water-voer verhouding & $\begin{array}{l}\text { Tweemaal daags voer: geen effect } \\
\text { Verdund voer: lagere } w-v \text { verhouding (beter ds } \\
\text { gehalte strooisel) }\end{array}$ \\
\hline & & & $10,15,20 \mathrm{wk}$ & Strooisel kwaliteit & Verdund voer: hoger ds\% gehalte strooisel \\
\hline & & & $20 \mathrm{wk}$ & Mestproductie & Meer mest bij tweemaal daags voeren \\
\hline & & & $23-40 w k$ & Eiproductie & $\begin{array}{l}\text { Tweemaal daags voer: iets eerder in productie en iets } \\
\text { meer eieren op } 30 \mathrm{wk} \\
\text { Verdund voer: geen effect }\end{array}$ \\
\hline & & & $29 \mathrm{wk}$ & Broederij resultaten & $\begin{array}{l}\text { Tweemaal daags voer: hogere bevruchting } \\
\text { Verdund voer: geen effect }\end{array}$ \\
\hline \multirow[t]{2}{*}{$\begin{array}{l}\text { Riber en Tahamtani } \\
(2020)\end{array}$} & Ross 308 / 1-19 wk & $\begin{array}{l}\text { Controle, onoplosbare vezel } \\
\text { (haverdoppen), mix } \\
\text { onoplosbare (haverdoppen) } \\
+ \text { oplosbare vezels } \\
\text { (bietenpulp), snijmais }\end{array}$ & $5,13,14 \mathrm{wk}$ & Strooisel kwaliteit & $\begin{array}{l}\text { Volgorde strooisel kwaliteit (van slecht naar goed): } \\
\text { mix, onoplosbaar, controle en +mais }\end{array}$ \\
\hline & & & $5,13,14 \mathrm{wk}$ & Ds gehalte strooisel & Voer met mais: hoogste ds $\%$ op alle leeftijden \\
\hline
\end{tabular}




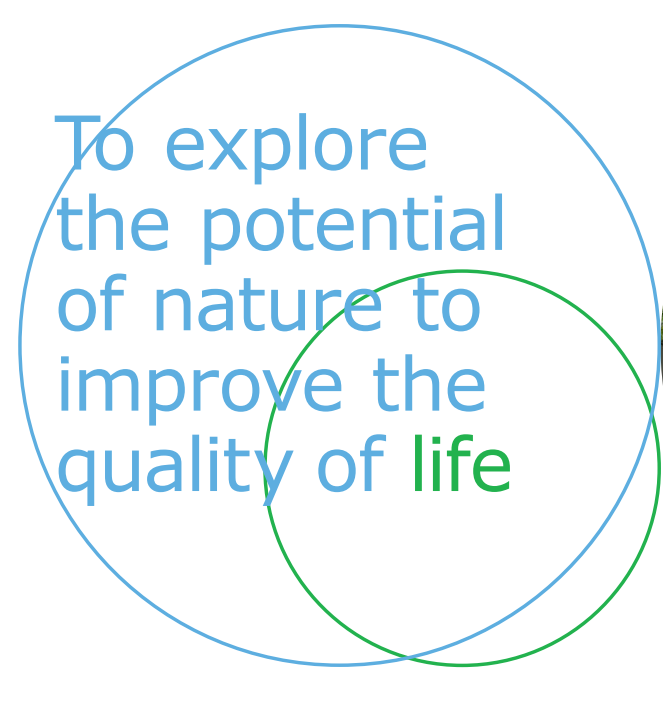

Wageningen Livestock Research Postbus 338

6700 AH Wageningen

T 0317483953

E info.livestockresearch@wur.nl www.wur.nl/livestock-research

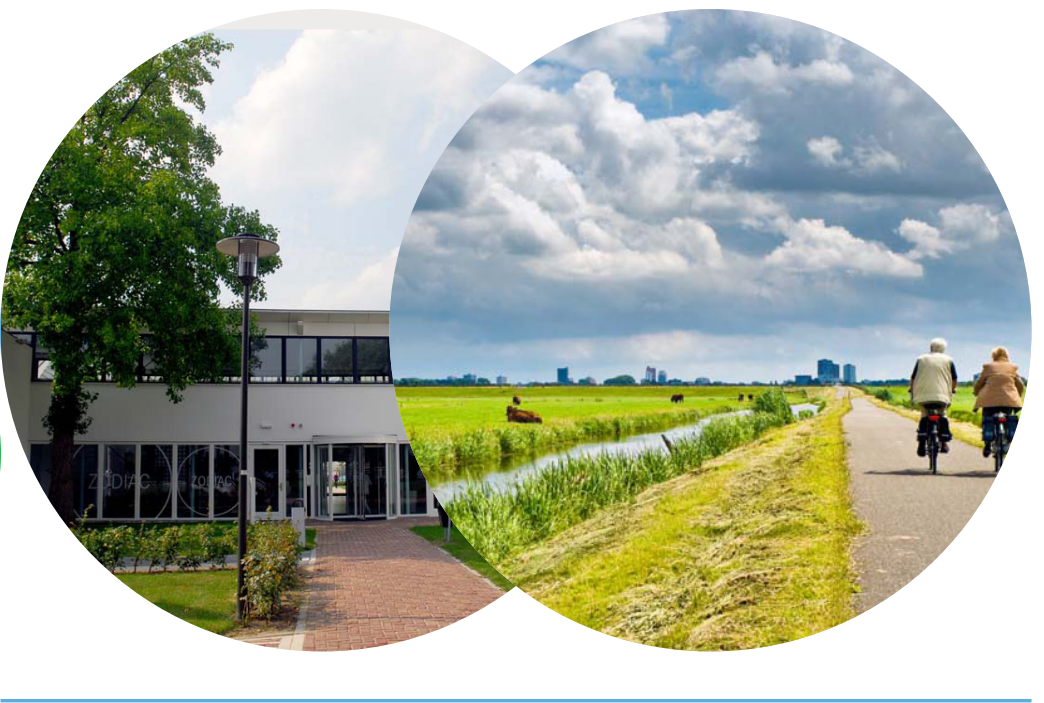

Wageningen Livestock Research ontwikkelt kennis voor een zorgvuldige en renderende veehouderij, vertaalt deze naar praktijkgerichte oplossingen en innovaties, en zorgt voor doorstroming van deze kennis. Onze wetenschappelijke kennis op het gebied van veehouderijsystemen en van voeding, genetica, welzijn en milieu-impact van landbouwhuisdieren integreren we, samen met onze klanten, tot veehouderijconcepten voor de 21 e eeuw.

De missie van Wageningen University \& Research is 'To explore the potential of nature to improve the quality of life'. Binnen Wageningen UR bundelen 9 gespecialiseerde onderzoeksinstituten van stichting DLO en Wageningen University hun krachten om bij te dragen aan de oplossing van belangrijke vragen in het domein van gezonde voeding en leefomgeving. Met ongeveer 30 vestigingen, 6.000 medewerkers en 10.000 studenten behoort Wageningen UR wereldwijd tot de aansprekende kennisinstellingen binnen haar domein. De integrale benadering van de vraagstukken en de samenwerking tussen verschillende disciplines vormen het hart van de unieke Wageningen aanpak. 